RUBERVAL FARIAS DA SILVA

\title{
Efeitos da estimulação ultra-sônica sobre a espermatogênese de ratos pré-púberes e adultos. \\ Estudo experimental.
}

Dissertação apresentada ao Programa de Pós Graduação Interunidades em Bioengenharia / Escola de Engenharia de São Carlos / Faculdade de Medicina de Ribeirão Preto / Instituto de Química de São Carlos / Universidade de São Paulo, como parte dos requisitos para Obtenção do título de Mestre em Bioengenharia.

Orientador: Prof. Dr. Affonso Luiz Ferreira

SÃO CARLOS

2007 
Dedico este trabalho à minha esposa Sandra.

Que deixou seus sonhos para que eu sonhasse.

Derramou lágrimas para que eu fosse feliz.

Perdeu noites de sono para que eu dormisse tranqüilo.

Acreditou em mim apesar dos meus erros.

O meu sincero e eterno agradecimento. 


\section{Agradecimento Especial}

Ao Professor Doutor Affonso Luiz Ferreira

Pela perseverança

Pela orientação segura

Pelo caráter e humildade

Pela competência e simplicidade

Pelo conhecimento e dedicação

Pela disponibilidade e paciência

Meu sincero agradecimento.

Bons Professores educam para uma profissão.

Professores fascinantes educam para a vida

Augusto Cury 
Aos colegas e amigos da pós-graduação, pelo companheirismo em todos os momentos.

A todos aqueles que sem avaliar o peso de suas atitudes auxiliaram direta ou indiretamente para a elaboração e conclusão deste trabalho, fica aqui a minha mais profunda gratidão. 


\section{RESUMO}

SILVA.R.F. (2007). Efeitos da estimulação ultrasônica sobre a espermatogênese de ratos pré-púberes e adultos. Estudo experimental. Dissertação (Mestrado)-Escola de Engenharia de São Carlos/Faculdade de Medicina de Ribeirão Preto/Instituto de Química de São Carlos, Universidade de São Paulo, São Carlos, 2007.

Esta investigação tem a finalidade estudar experimentalmente os efeitos do UltraSom Pulsado de Baixa Intensidade sobre a espermatogênese de ratos pré-púberes e adultos. Foram utilizados 40 ratos machos da raça Wistar, sendo 20 pré-púberes e 20 adultos, os quais tiveram os testículos estimulados por 15 minutos durante 10 dias consecutivos. Cada grupo experimental constou de 10 animais pré-púberes ou adultos, estimulados com o Ultra-som Pulsado de Baixa Intensidade ou não estimulados. Administrou-se Colchicina, 6 horas antes do sacrifício dos animais com a finalidade de bloquear a divisão das células em metáfase para facilitar a avaliação do ciclo espermatogenético. Mediante morfometria estimou-se as áreas dos túbulos seminíferos e fez-se a avaliação dos estadios do ciclo espermatogenético quando foi constatado um aumento significativo das áreas dos túbulos seminíferos dos animais estimulados. O ciclo espermatogenético de ratos pré-púberes e adultos foi avaliado mediante contagens de associações celulares do ciclo nos estadios VII e VIII e XIV, correspondentes ao fim e inicio de cada ciclo. Houve aumento temporal do ciclo espermatogenético por apresentar maior número de associações com características dos estadios VIII significando acentuada maturidade de espermatozóides nos ratos pré-púberes estimulados. Os testículos dos animais adultos estimulados apresentaram aumento de peso em relação aos dos controles, exibindo uma diferença significativa. Nossos resultados são compatíveis com a hipótese de que o Ultra-Som Pulsado de Baixa Intensidade estimula o aumento do peso dos testículos dos ratos adultos e das áreas dos túbulos seminíferos, bem como acelerando o ciclo espermatogenético em ratos pré-púberes.

Palavra chave: ultra-som pulsado de baixa intensidade, testículos pré-púberes, adultos e espermatogênese. 


\section{Abstract}

SILVA.R.F. (2007). Effects of the stimulation ultrasonic about for spermatogenesis of rats prepubertal and adult. Experimental study. M Sc. Dissertation - Escola de Engenharia de São Carlos/Faculdade de Medicina de Ribeirão Preto/Instituto de Química de São Carlos, Universidade de São Paulo, São Carlos, 2007.

This is an experimental study of the effects of Low Intensity Pulsed Ultrasound on the spermatogenesis of prepubertal and adult male rats. Forty male Wistar rats - twenty prepubertal and twenty adults -, whose testicles were stimulated for fifteen minutes for ten consecutive days were studied. Each experimental group was composed of ten prepubertal or adult animals, stimulated with Low Intensity Pulsed Ultrasound or not. Six hours before killing, the rats were given Colchicine to block the division of metaphasic cells, in order to facilitate the assessment of the spermatogenetic cycle. The area of the seminiferous tubule was done estimated by morphometry and the stages of spermatogenetic cycle were assessed, showing a significant increase of the areas of the seminiferous tubules of the stimulated animals. The spermiogenesis of prepubertal and adult rats was assessed through counts of cell associations in the stages VII and VIII and XIV, corresponding to the end and beginning of each cycle. There was a temporal increase in the spermatogenetic cycle due to a higher number of the associations with stage VIII characteristics, which means accentuated sperm cell maturity of the stimulated prepubertal rats. The testicles of the stimulated animals were weight increase regarding the of the control animals, showing a significant difference. Our results are compatible with the hypothesis that the Low Intensity Pulsed Ultrasound stimulates the increase of the testicle weight, the rats adults, and the area of the seminiferous tubules as well as accelerating the spermatogenetic cycle in rats prepubertal.

Key-words: low intensity pulsed ultrasound, adult and prepubertal testicles, and spermatogenesis. 


\section{Lista de Figuras}

1 Interligação da forças elásticas na matéria. .................. 22

2 Onda Longitudinal. .............................. 23

3 Estadios do ciclo do epitélio germinativo. .................... 54

4 Aparelho de Ultra-som pulsátil de baixa intensidade. . . . . . . . . . . . . . . 59

5 A fotografia mostra o transdutor ultra-sônico a ser acoplado à bolsa escrotal

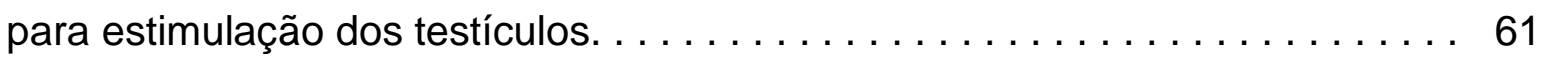

6 A fotografia mostra o transdutor ultra-sônico a ser acoplado à bolsa escrotal para estimular os testículos dos animais na posição ventral . . . . . . . . 61

7 A fotografia mostra o transdutor ultra-sônico a ser acoplado à bolsa escrotal para estimular os testículos dos animais na posição dorsal . . . . . . . . . 62

8 Estrutura química da Colchicina. ........................ 63

9 Fotografia de testículos de ratos pré-púberes e adultos estimulados ou não. . . 65

10 Fotomicrografia de cortes transversais de túbulos seminíferos de animais prépúberes $(A$ e B) e ( $C$ e D) adultos estimulados ou não, caracterizando o estadio VII do ciclo espermatogenético. .................... 68

11 Fotomicrografia de cortes transversais de túbulos seminíferos de animais prépúberes $(A$ e B) e ( $C$ e D) adultos estimulados ou não, caracterizando o estadio VIII do ciclo espermatogenético. . . . . . . . . . . . . . . . . . 69

12 Fotomicrografia de cortes transversais de túbulos seminíferos de animais prépúberes $(A$ e B) e ( $C$ e D) adultos estimulados ou não, caracterizando o estadio XIV do ciclo espermatogenético.

13 Fotomicrografia de túbulos seminíferos em cortes transversal de testículos de rato pré-púbere controle. As setas indicam os túbulos que representam o 
estadio VII do ciclo espermatogenético. . . . . . . . . . . . 71

14 Fotomicrografia de túbulos seminíferos em cortes transversal de testículo de rato pré-púbere estimulado. As setas indicam os túbulos que representam 0

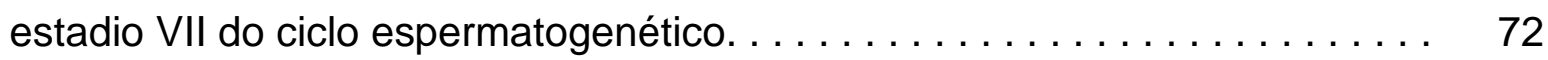

15 Fotomicrografia de túbulos seminíferos em cortes transversal de testículo de rato adulto controle. As setas indicam os túbulos que representam o estadio

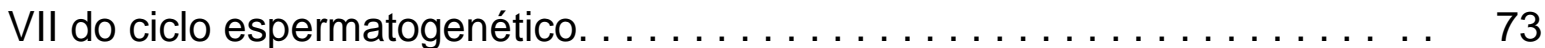

16 Fotomicrografia de túbulos seminíferos em cortes transversal de testículo de rato adulto estimulado. As setas indicam os túbulos que representam o estadio do VII do ciclo espermatogenético. . . . . . . . . . . . .

17 Fotomicrografia de túbulos seminíferos em cortes transversal de testículo de rato pré-púbere controle. As setas indicam os túbulos que representam o estadio do VIII do ciclo espermatogenético.

18 Fotomicrografia de túbulos seminíferos em cortes transversal de testículo de rato pré-púbere estimulado. As setas indicam os túbulos que representam o estadio do VIII do ciclo espermatogenético.

19 Fotomicrografia de túbulos seminíferos em cortes transversal de testículo de rato adulto controle. As setas indicam os túbulos que representam o estadio do VIII do ciclo espermatogenético.

20 Fotomicrografia de túbulos seminíferos em cortes transversal de testículo de rato adulto estimulado. As setas indicam os túbulos que representam o esta-

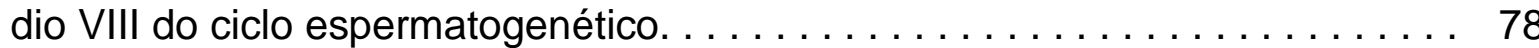

21 Fotomicrografia de túbulos seminíferos em cortes transversal de testículo de rato pré-púbere controle. As setas curtas indicam os túbulos que representam o estadio XIV do ciclo espermatogenético. 
22 Fotomicrografia de túbulos seminíferos em cortes transversal de testículo de rato pré-púbere estimulado. As setas curtas indicam os túbulos que representam o estadio XIV do ciclo espermatogenético. . . . . . . . . . . .

23 Fotomicrografia de túbulos seminíferos em cortes transversal de testículo de rato adulto controle. As setas curtas indicam os túbulos que representam o estadio XIV do ciclo espermatogenético. . . . . . . . . . . . . . . .

24 Fotomicrografia de túbulos seminíferos em cortes transversal de testículo de rato adulto estimulado. As setas curtas indicam os túbulos que representam o estadio XIV do ciclo espermatogenético. 


\section{Listas de Tabelas}

1 Coeficiente de absorção em diferentes tecidos. . . . . . . . . . . . . . 27

2 Parâmetros do Ultra-som utilizados no experimento. . . . . . . . . . . 60

3 ANOVA $(\alpha=0,05)$ Estadios do Ciclo Espermatogenético de Ratos Adultos estimulados e não estimulados. . . . . . . . . . . . . . . . . . . . 83

4 ANOVA $(\alpha=0,05)$ Freqüência dos Estadios do Ciclo Espermatogenético de Ratos Pré-Púberes Estimulados e não Estimulados. . . . . . . . . . . . . . . . . . 84

5 ANOVA $(\alpha=0,05)$ Freqüência dos Estadios do Ciclo Espermatogenético de Ratos Pré-Púberes e Adultos Estimulados e não Estimulados. . . . . . . . . . . . 85

6 ANOVA $(\alpha=0,05)$ Área dos Túbulos Seminíferos dos Testículos de Ratos Pré-Púberes e Adultos Estimulados e não Estimulados. . . . . . . . . . . . . 86

7 ANOVA $(\alpha=0,05)$ Área dos Túbulos Seminíferos dos Testículos de Ratos Adultos Estimulados e não Estimulados. . . . . . . . . . . . . . . . . 87

8 ANOVA $(\alpha=0,05)$ Peso dos Testículos de Ratos Adultos Estimulados e não Estimulados. . . . . . . . . . . . . . . . . . . . . . . . . . . . . 89 


\section{Lista de Gráficos}

1 Representação gráfica da freqüência dos estadios VII, VIII e XIV em testículos de animais adultos estimulados ou não com ultra-som pulsado. . . . . . . . . . 83

2 Representação gráfica da freqüência dos estadios VII, VIII e XIV em testículos de animais pré-púberes estimulados ou não com ultra-som pulsado. . . . . . . . 84

3 Representação gráfica da freqüência dos estadios VII, VIII e XIV em testículos de animais adultos e pré-púberes estimulados ou não com ultra-som pulsado. . . 85

4 Representação gráfica da morfométria das áreas dos túbulos seminíferos de testículos de ratos pré-púberes estimulados ou não com ultra-som pulsado. . . . 86

5 Representação gráfica da morfométria das áreas dos túbulos seminíferos de testículos de ratos adultos estimulados ou não com ultra-som pulsado. .

6 Representação gráfica das áreas dos túbulos seminíferos de testículos de ratos adultos e pré-púberes estimulados ou não com ultra-som pulsado. . . . . . . . 88

7 Representação gráfica dos pesos dos testículos de animais adultos estimulados com ultra-som pulsado de baixa intensidade. 


\section{Lista de Abreviaturas}

ABP - Proteína transportadora de andrógenos

AC - Adulto Controle

ACTH - Hormônio da adrenocorticóide

AE - Adulto Estimulado

AMH - Hormônio anti-mulleriano

ATP - Adenosina Tri - fosfato

CA - Controle Adulto

CPP - Controle Pré-Púbere

cm - Centímetro

DHT - 5 - Dihidrotestosterona

DNA - Ácido desoxirribonucléico

EA - Estimulado Adulto

EPP - Estimulado Pré-Púbere

F - Resultado da tabela ou valor estatístico

FSH - Hormônio Folículo Estimulante

GL - Grau de Liberdade

GNRH - Hormônio Liberador de Gonadotrofinas

GTP - Trifosfato de guanosina

HE - Hemalumem e Eosina

HCG - Hormônio Corionico Gonadotrofico

Hz - Hertz - unidade de medida de freqüência

kHz - Kilohertz

LH - Hormônio Luteinizante

$\mathbf{m g} / \mathbf{d l}$ - miligrama por decilitro

MHz - Mega Hertz 
mm- Milímetros

MQ - Média dos quadrados

$\mathbf{m} / \mathbf{s}$ - Metros por segundo

$\mathbf{m W} / \mathbf{c m}^{2}$ - Miliwatt por centímetro quadrado

NADPH - Nicotinamida adenina de fosfato dinucleotideo

PPC - Pré-Púbere Controle

PPE - Pré-Púbere Estimulado

PZT - Titanato zirconato de chumbo

RONs - Regiões organizadoras de nucléolos

RNA - Ácido Ribonucléico

SHBG - Globulina transportadora de hormônios sexuais

SATA - Spatial average temporal average - média espacial, média temporal.

SNC -Sistema Nervoso Central

SQ - Soma de quadrados

TCD - Testículo Controle Direito

TCE - Testículo Controle Esquerdo

TED - Testículo Estimulado Direito

TEE - Testículo Estimulado Esquerdo

VF - Valor F (Tabela) ou valor estatístico

VL -Velocidade da onda longitudinal

W/cm² - Watt por centímetro quadrado

$\mu \mathrm{m}$ - micrometros

$\mu \mathrm{m} / \mathrm{s}$ - micrometro por segundo 


\section{SUMÁRIO}

1 INTRODUÇÃO 17

2 REVISÃO DA LITERATURA

2.1 O Ultra-som. . . . . . . . . . . . . .

2.1 .1 Transdutores. . . . . . . . . . . . . . . . . . . . . 22

2.1 .2 Ondas Ultra-sônicas. . . . . . . . . . . . . . . . . . . 23

2.1.3 Características das Ondas Ultra-sônicas. . . . . . . . . . . . . 24

2.1 .4 Velocidade de Propagação. . . . . . . . . . . . . . . . . . . . 25

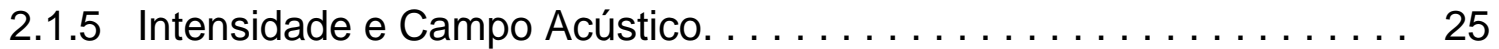

2.1.6 Mecanismos de Atenuação. . . . . . . . . . . . . . . . 27

2.1.7 Mecanismo de Interação do Ultra-som com Células e Tecidos

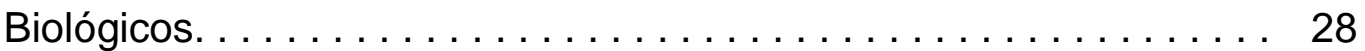

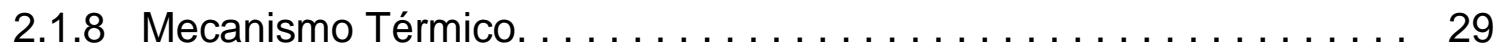

2.1 .9 Fluxo e Microfluxo Acústico. . . . . . . . . . . . . . . . . . . 31

2.1.10 Piezeletricidade. . . . . . . . . . . . . . . . . . . 31

2.1.11 Os Efeitos do Ultra-som nas Diferentes Fases do Reparo Tecidual. . 32

2.1.12 Lise ou Morte Celular. . . . . . . . . . . . . . . . . . . . . . . . . . . 34

2.2 Alguns Aspectos Estruturais dos Órgãos Reprodutores de Ratos Machos. . 34

2.2.1 Sistema Genital Masculino. . . . . . . . . . . . . . . . 36

2.2 .2 As Células de Sertoli. . . . . . . . . . . . . . . . . . . . . . . 41

2.2.3 Regulação da Síntese de Testosterona. . . . . . . . . . . . . . . . . . . . 44

2.2.4 Principais Ações dos Andrógenos. . . . . . . . . . . . . . . 45

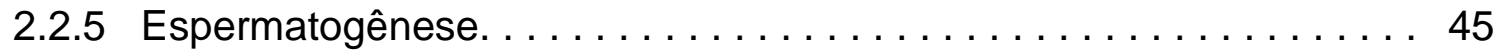

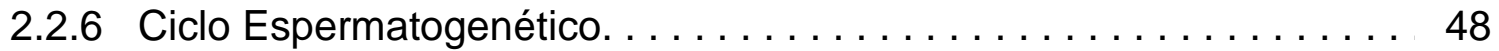

2.2 .7 O Espermatozóide. . . . . . . . . . . . . . . . . 48

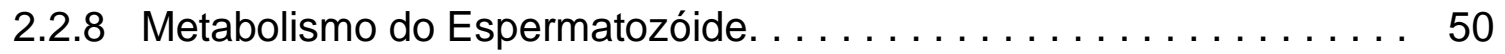

2.2.9 Duração do Ciclo Espermatogenético. . . . . . . . . . . . . . . . 51 
2.2.10 Estadios Evolutivos da Espermatogênese. . . . . . . . . . . 52

3 OBJETIVO 56

4 MATERIAL E MÉTODOS $\quad 57$

4.1 Animais de Experimentação. . . . . . . . . . . . . . . . . . 57

4.2 Equipamento Gerador de Ultra-som e Parâmetros Usados. . . . . . . . . . . 59

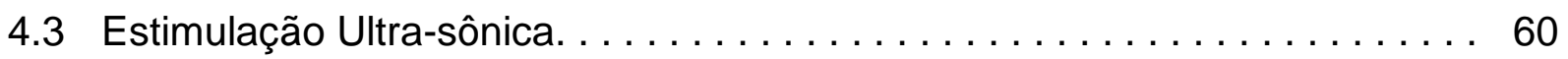

4.4 A Colchicina como Agente Mitostático. . . . . . . . . . . . . . . . . 63

4.4.1 Uso da Colchicina. ........................... 63

4.5 Coleta de Material. . . . . . . . . . . . . . . . . . . . . . . 64

4.6 Análise Morfométrica e Estatística. . . . . . . . . . . . . . . . 66

5 RESULTADOS $\quad 67$

6 DISCUSSÃO 90

7 CONCLUSÃO $\quad 96$

8 REFERÊNCIAS BIBLIOGRÁFICAS

9 APÊNDICE 103 


\section{1 - Introdução}

O aparelho de Ultra-Som Pulsado de Baixa Intensidade foi elaborado e montado na Escola de Engenharia da Universidade de São Paulo no setor de Bioengenharia na cidade de São Carlos. Foi inicialmente utilizado e patenteado para corrigir falhas ósseas em pseudo-artroses e fraturas.

As pesquisas sobre aplicações da energia ultra-sônica pulsada de baixa intensidade tiveram em nosso País e na América Latina, como pioneiro, o Professor Luiz Romariz Duarte e sua equipe da Escola de Engenharia de São Carlos/USP, esses estudos já realizados mostraram que o ultra-som pulsado de baixa intensidade acelera a formação de osso primário e o reparo de fraturas ósseas experimentais ou não.

(DUARTE, 1977, 1983), atribuiu a aceleração do processo de consolidação de fraturas ósseas pelo ultra-som de baixa intensidade ao mecanismo de piezeletricidade desencadeando assim uma série de pesquisas de grande importância na consolidação do tecido ósseo lesado.

Atualmente, sua ação tem sido estendida na avaliação dos efeitos da radiação ultra-sônica sobre os mais variados tecidos e em certas condições patológicas, como ulceras cutânea, com excelentes resultados. (PAUL; COLS, 1960. GALITSKY; LEVINA, 1964 e HILÁRIO 1993).

(ALVES, 1988), mostrou os efeitos da energia ultra-sônica pulsada e de baixa intensidade na regeneração da pele de rato, lesada experimentalmente por queimaduras de terceiro grau, mostrando ser capaz de acelerar o reparo dos tecidos queimados e da epidermia. O estimulo ultra-sônico intensificou a formação de tecido de granulação, além de favorecer a regeneração da pele e de alguns de seus anexos como glândulas e folículos pilosos, fato pioneiro no uso da radiação sônica que induziu o uso do Ultra-som em diferentes tipos de tecidos. 
As pesquisas relacionadas aos efeitos do ultra-som pulsado, no reparo de fraturas tiveram continuidade, e vários trabalhos experimentais e recentes, confirmaram os efeitos que já houvera sido demonstrado inicialmente, considerando que os mecanismos mediante os quais o ultra-som pulsado atua sobre o tecido ósseo não estão ainda perfeitamente esclarecidos (ITO et al., 2000). Esses autores admitem que outros fatores sistêmicos ou fatores secundários de crescimento estariam também envolvidos no processo de reparação de fraturas quando estimuladas pelo Ultra Som Pulsado de Baixa Intensidade.

(MAYER et al., 2000), consideram que o ultra-som pulsado provê um método não invasivo de grande valia no processo de reparo de fraturas.

(TIS et al., 2001), utilizando Ultra-som Pulsado de Baixa Intensidade em estudos clínicos ou experimentais realizados em camundongos, mostraram sua eficácia na formação de osso primário após fratura; na pseudo-artrose, e quando da implantação de próteses.

(NARUSE et al., 2000), consideraram que o ultra-som pulsado de baixa intensidade favorece o reparo de fraturas induzindo uma reação anabólica direta de células osteogênicas, conduzindo à formação de tecido ósseo primário.

Estes mesmos autores demonstraram que o Ultra-som Pulsado de Baixa Intensidade induziu maior produção da osteocalcina usando para estas conclusões estudos sobre medula óssea de rato.

(MACHEN et al., 2001), em estudos realizados IN VITRO mostraram um significante aumento da expressão de genes condrogênicos bem como também o aumento na incorporação de cálcio em condrócitos. Estes mesmos pesquisadores em estudos IN VITRO demonstraram também uma maior produção do cálcio, incorporada a osteoblastos em cultura.

A maior parte das evidências indicam um efeito do Ultra-som sobre os condroblastos. Esses autores declararam que o reparo ósseo seria resultante de uma formação aumentada de cartilagem ou da excitação osteoblástica na formação do calo ósseo.

(KOKUBU et al., 1999), demonstraram experimentalmente que o Ultra-som Pulsado de Baixa Intensidade aumenta a produção de prostaglandina, via indução da ciclooxigenase I e II.

(GEBEAUER et al., 2002), demonstraram experimentalmente a efetividade do Ultra-som Pulsado de Baixa Intensidade no reparo de fraturas em portadores de 
Diabetes Mellitus.

(HWANG et al., 2004), divulgaram aumento da resistência ao torque em 29\% de fêmures fraturados cujos calos ósseos foram induzidos após aplicação do Ultrasom Pulsado de Baixa Intensidade. Os autores citados e o uso do Ultra-som pulsado em diferentes tecidos vêm apenas a confirmar a amplitude de suas eventuais aplicações.

Constata-se assim, numa revisão da Literatura, que o Ultra-som Pulsado de Baixa Intensidade atua efetivamente no reparo de tecidos, quer sobre lesões provocadas experimentalmente, quer em lesões decorrentes de processos patológicos já instalados mostrando-se, mediante mecanismos ainda não bem esclarecidos, capaz de regenerar tecidos bem como acelerar o processo cicatricial.

Os efeitos deletérios ou benéficos do ultra-som pulsado de baixa intensidade em meio biológico estão intimamente relacionados com as características e com os efeitos das ondas acústicas por ele geradas. (HILL, 1972).

Por outro lado mostrou-se também que os efeitos da aplicação do ultra-som pulsado de baixa intensidade não provoca danos em tecidos animais, e sua ação biológica é atribuída a diferentes mecanismos, térmicos e não-térmicos. (DYSON, 1987).

Entretanto, poucos trabalhos têm sido encontrados na Literatura sobre efeitos do Ultra-Som Pulsado de Baixa Intensidade sobre processos biológicos complexos como a espermatogênese, tanto quanto sobre outras glândulas endócrinas e paracrinas ou quanto sobre a fibra muscular lisa.

Contrastando com os inúmeros trabalhos sobre os efeitos do Ultra-Som Pulsado de Baixa Intensidade no reparo ósseo e na formação de tecido ósseo primário, (DUARTE, 1977,1983), poucos são aqueles trabalhos referentes ao seu uso sobre estruturas e componentes de processos biológicos complexos como o ciclo espermatogenético, representado por uma seqüência repetitiva de varias gerações celulares, e dependentes também de uma ação hormonal cíclica repetitiva.

Apenas o trabalho elaborado por (HADDAD, 1992), no qual utiliza também o Ultra-som pulsado para estimar seus efeitos sobre testículos de ratos pré-púberes, púberes e adultos, não foi possível encontrar outros trabalhos sobre este mesmo assunto na Literatura consultada. A referida autora não encontrou variações na "dinâmica da espermatogênese", embora tivesse registrado um aumento na concentração de testosterona, no plasma de animais pré-púberes, quando 
estimulados. Paradoxalmente o Ultra-som pulsado de baixa intensidade não estimule a espermatogênese, mas provoca, entretanto, aumento significativo na atividade androgênica das células de Leydig, segundo a mesma Autora.

Esses achados nos estimularam a usar o Ultra-Som Pulsado de Baixa Intensidade sobre testículos de ratos adultos e pré-púberes da raça Wistar, a fim de avaliar seus efeitos sobre a seqüência de estadios do ciclo espermatogenético, além de avaliações do ciclo, foram medidas morfometricamente as áreas dos túbulos seminíferos, avaliando-se também o peso dos testículos dos animais adultos estimulados ou não. 


\section{2- Revisão da Literatura}

\section{1 - Ultra - Som}

O termo ultra-som refere-se a ondas sonoras com freqüência superior a 20 kHz. A primeira aplicação prática do Ultra-Som foi em 1917 com a criação de sonares para a detecção de submarinos, utilizando o método pulso-eco. Alguns anos mais tarde, descobriram que o Ultra-Som produzia aumento da temperatura em tecidos biológicos. Em torno do ano de 1930 até 1940, o Ultra-Som foi introduzido na prática médica como um recurso terapêutico, usado particularmente para produzir calor em tecidos profundos.

Após 1940 até os dias atuais, o Ultra-Som vem sendo extensamente usado em áreas médicas e industriais, e novos efeitos e aplicações do Ultra-Som vem sendo pesquisados.

A interação da energia ultra-sônica com os tecidos biológicos produz efeitos danosos ou benéficos, dependendo da variação de parâmetros da onda acústica, tais como intensidade média, freqüência, amplitude e tempo de exposição.

No caso das ondas pulsadas, a largura do pulso, sua freqüência de repetição, e a intensidade instantânea são parâmetros importantes na produção dos seus efeitos biológicos.

O Ultra-Som é transmitido sob a forma de ondas de compressão, onde a oscilação de partículas se dá paralelamente à direção de propagação da onda, constituindo zonas de compressão e rarefação, ou em forma de ondas de cisalhamento (somente para os sólidos), onde as partículas oscilam em direção perpendicular à direção de propagação das ondas.

As ondas ultra-sônicas são ondas mecânicas e transmitem energia através da matéria causando uma oscilação nas posições de equilíbrio das suas partículas. 
Como sabemos toda substância é constituída por partículas, Imaginemos que esta substância seja composta de pequenas partículas de matéria, as quais estão interligadas por forças elásticas, podendo se mover em relação às suas posições de equilíbrio.

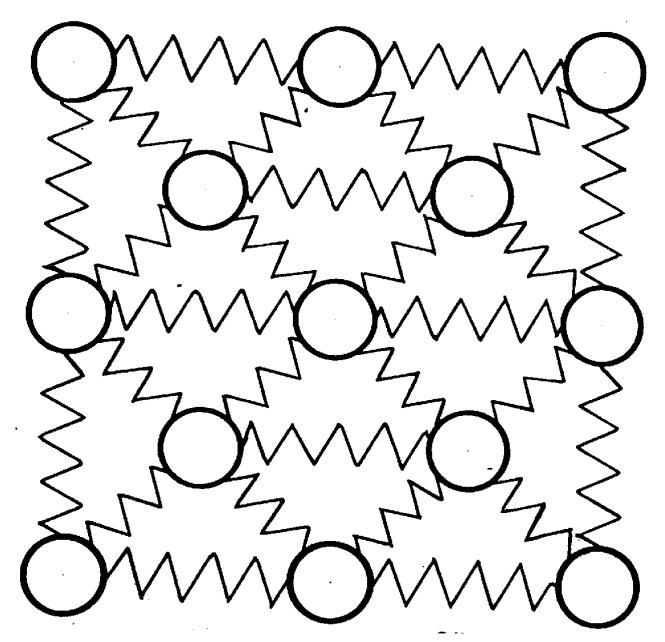

Figura 1: Interligação das forças elásticas na matéria.

Quando uma partícula é impulsionada, ela começa a vibrar e passa sua energia para as partículas adjacentes. Deste modo, a energia se propaga de uma partícula para as outras partículas da substância.

O número de vibrações na unidade de tempo (freqüência) nos informa se é gerado infra-som, som audível ou ultra-som. É importante salientar que as partículas do meio em que se propaga à energia não caminham junto com a onda e sim executam um movimento de vibração ao longo de um eixo orientado.

\subsection{1- Transdutores}

São dispositivos com a capacidade de responder a uma tensão elétrica, deformando-se, ou a uma tensão mecânica, alterando a sua polarização.

O ultra-som de uso médico, fisioterapêutico e odontológico é produzido por transdutores ultra-sônicos.

Os transdutores ultra-sônicos convertem energia elétrica em energia mecânica, produzindo ondas contínuas ou pulsadas, que podem atravessar grandes distâncias em meios gasosos, líquidos ou sólidos. 
Alguns cristais naturais como o quartzo e a turmalina são piezelétricos podendo ser usados como transdutores. No entanto, alguns transdutores podem ser produzidos artificialmente como de Titanato de Bário (BaTiOs) e o Zirconato Titanato de Chumbo (PZT), por exemplo.

\subsection{2 - Ondas ultra-sônicas}

Dependendo do modo de vibração distinguimos três tipos básicos de ondas ultra-sônicas: ondas longitudinais, ondas transversais e ondas superficiais.

Onda longitudinal (ou de compressão): Aquela na qual as partículas do meio vibram na mesma direção da propagação da onda (figura 2).

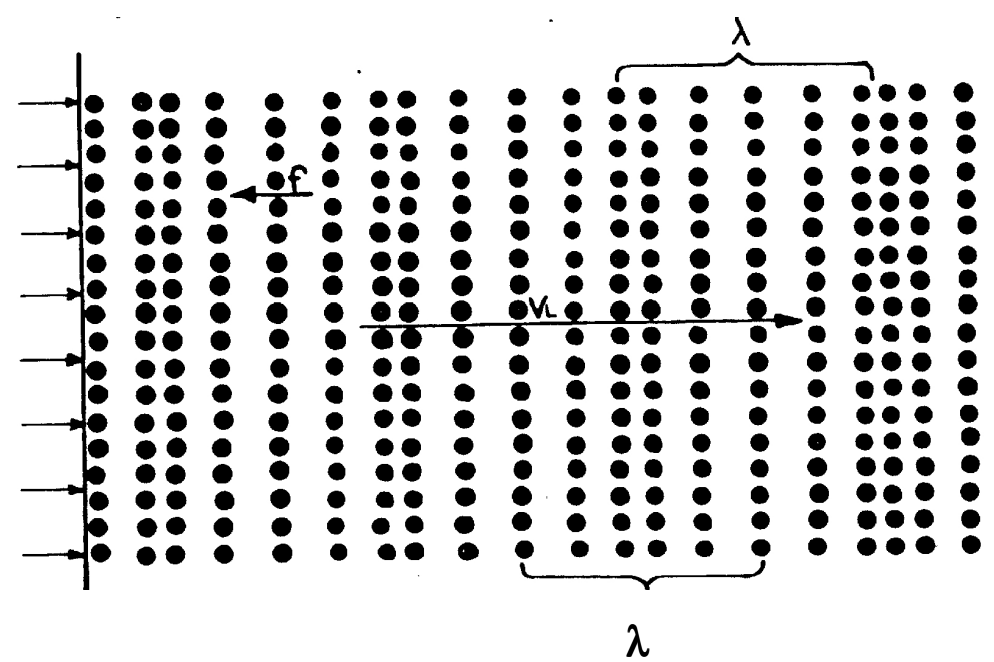

Figura 2: Onda Longitudinal.

Em distâncias iguais existem compressões de planos de partículas e entre eles, encontram-se "zonas diluídas". As distâncias entre duas zonas de compressão determinam o comprimento de onda $(\lambda)$ de uma onda longitudinal.

As zonas de compressão e de diluição movem-se através do corpo de prova com uma certa velocidade $V_{L}$ que é a velocidade da onda longitudinal. Esta velocidade do som é uma constante do material, isto é, difere de acordo com o material no qual a onda é propagada. Portanto, a velocidade do som pode ser considerada constante em um material totalmente homogêneo.

A freqüência (f) indica o número de vibrações por segundo efetuado por cada partícula. 
A correlação matemática dos três elementos sendo definidos pela equação $n^{0}$ 1 é:

$$
\mathrm{V}_{\mathrm{L}}=\mathrm{f} \cdot \lambda
$$

Como a velocidade do som é uma constante do material, a escolha de uma certa freqüência determinará o comprimento da onda ultra-sônica.

A velocidade de propagação do som de uma onda longitudinal pode ser calculada pela equação de $n^{\circ} 2$ :

$$
\mathrm{V}_{\mathrm{L}}=\sqrt{\frac{\mathrm{E} \cdot(1-\mu)}{\rho .(1+\mu) \cdot(1-2 \mu)}}
$$

Sendo: $\quad E=$ módulo de elasticidade de Young $\left(\mathrm{N} / \mathrm{m}^{2}\right)$

$$
\begin{aligned}
& \mu=\text { constante de Poisson } \\
& \rho=\text { densidade do material }\left(\mathrm{kg} / \mathrm{m}^{3}\right)
\end{aligned}
$$

\subsection{3 - Características das ondas ultra-sônicas}

As ondas ultra-sônicas apresentam características dos demais tipos de ondas.

$O$ comprimento da onda $(k)$, corresponde à distância entre regiões adjacentes de compressão ou de rarefação máxima, cujas partículas encontra-se em um mesmo estado de movimento, em um dado instante de tempo.

Amplitude ( $A)$, corresponde ao deslocamento máximo que uma partícula experimenta a partir de sua posição de equilíbrio. Descreve a magnitude do distúrbio causado pela onda.

Período $(T)$, é o intervalo de tempo necessário para que uma partícula realize um ciclo completo de movimento. 
Potência $(P)$, energia $(E)$, total do feixe em um intervalo de tempo $(\mathrm{t})$, expressa em Watts.

Freqüência (f), corresponde ao número de vezes que uma partícula realiza um ciclo por unidade de tempo.

Intensidade (I), energia que atravessa uma unidade de área numa unidade de tempo $(\mathrm{W} / \mathrm{cm})$, quando uma onda atravessa um meio às partículas vibram e adquirem energia cinética, essa energia associada com a onda ultra-sônica é chamada de intensidade acústica.

Atenuação, redução da intensidade de uma onda ultra-sônica conforme ela se distância de sua fonte, causado por espalhamento e absorção pelo meio.

Tempo de irradiação, tempo total de exposição.

\subsection{4 - Velocidade de propagação (c)}

A velocidade de propagação de uma onda (c) é definida como a distância percorrida pela onda ultra-sônica por unidade de tempo.

No entanto, a velocidade de onda ultra-sônica depende do tipo de onda considerada e das constantes elásticas do meio em que se propaga.

A velocidade de propagação das ondas sonoras decresce dos meios sólidos para os líquidos e destes para os gasosos. Nos tecidos moles do corpo humano a velocidade de propagação da onda ultra-sônica está ao redor de $1.500 \mathrm{~m} / \mathrm{s}$. (YOUNG, 1990),

\subsection{5- Intensidade e campo acústico}

È quando uma onda atravessa um meio, as partículas do meio começam a vibrar e adquirem energia cinética. A energia associada com a onda ultra-sônica é chamada é chamada de intensidade acústica. E a energia fornecida pelas ondas ultra-sônicas ao atravessar o meio é medida pela intensidade acústica.

A intensidade que caracteriza o campo acústico transmitido pelo transdutor é medida através de dosímetros de ultra-som em um meio de baixa atenuação normalmente em água. 
Esses dosímetros medem a força de radiação $(F)$, possibilitando assim o cálculo da potência acústica $(P)$, e conseqüentemente da intensidade acústica temporal e espacial média, que é definida como o quociente entre a potência acústica total transmitida e a área do transdutor.

A intensidade apresenta características diferentes no campo acústico, caracterizando no campo duas regiões distintas: o campo próximo ou zona de Fresnel e o campo distante ou zona de Fraunhofer. No campo próximo a intensidade é disforme, enquanto que no campo distante ela decresce suavemente com a distância da fonte.

As ondas ultra-sônicas podem se propagar de dois modos, o contínuo e o pulsado, a diferença entre estes dois modos está na interrupção da propagação de energia.

No modo contínuo não ocorre esta interrupção, havendo um depósito ininterrupto de energia sobre os tecidos irradiados.

No modo pulsado, no entanto, há interrupções freqüentes na propagação de energia. Na utilização do modo pulsado, existem dois tipos de freqüências a serem consideradas, que são a freqüência da onda (f), e a freqüência de repetição de pulso $(\mathrm{Fr})$. As ondas ultra-sônicas podem apresentar um fenômeno exclusivo dos movimentos ondulatórios denominado interferência. E esta interferência corresponde à combinação de duas ou mais ondas em um ponto do meio onde se propagam, podendo ser construtiva ou autodestrutiva.

A interferência construtiva ocorre com a superposição de ventre de ondas que se somam formando um ventre com maior amplitude. A interferência autodestrutiva ocorre com a superposição de ondas com sinais invertidos, tendendo a se anularem.

Essas interferências ocorrem, por exemplo, quando há reflexão de ondas com a formação de ondas estacionárias. Ondas estacionárias são ondas que refletidas ficam confinadas a um determinado espaço e que ao se sobreporem podem se anular ou se somar. (WELLS, 1977).

Como a intensidade é proporcional ao quadrado da amplitude, deve-se procurar evitar a formação de ondas estacionárias, pois a formação de ondas construtivas pode elevar muita a amplitude e danificar os tecidos irradiados.

\subsection{6 - Mecanismos de Atenuação}


A atenuação corresponde ao decréscimo da intensidade em função da distância da fonte sonora, e ocorre devido a fatores geométricos (dimensões da fonte sonora, comprimento de onda, presença de superfícies refletoras, etc.), e por mecanismos de absorção (viscosidade, tempo de relaxação, etc.). Estes mecanismos possuem características diferentes de acordo com o meio. Nos tecidos biológicos a atenuação deve-se principalmente aos mecanismos de absorção. E este mecanismo de energia mecânica das ondas do ultra-som é convertido em calor. (TER HAAR, 1978). O coeficiente de absorção (a) é diferentemente proporcional à freqüência, e quanto maior a freqüência, mais rápida é a absorção. (TER HAAR, 1987),

A Tabela 1 mostra o coeficiente de absorção para a freqüência de $1 \mathrm{MHz}$ em diferentes meios.

Tabela 1 - Coeficiente de absorção (a) em diferentes tecidos para freqüência de $1 \mathrm{MHz}$ (WELLS, 1977).

\section{TECIDOS}

Cérebro

Fígado

Gordura

Miocárdio

Músculos (paralelo às fibras)

Músculos (transversal às fibras)

Ossos do crânio

Pulmão

Rim

Sangue
Coeficiente de absorção (a)

0,85

0,94

0,63

1,80

1,30

3,30

20,0

41,0

1,00

0,18

\subsection{7 - Mecanismos de interação do ultra-som com células e tecidos biológicos}

Os efeitos biológicos da ação do ultra-som dependem de muitos fatores físicos e biológicos, tais como intensidade, tempo de exposição, estrutura espacial e 
temporal do campo ultra-sônico e estado fisiológico do objeto.

Este grande número de variáveis complica a compressão exata do mecanismo de ação do ultra-som na interação com os tecidos biológicos. (SARVAZYAN, 1983).

Experimentos realizados com o ultra-som demonstram que a interação deste com os tecidos biológicos provoca alterações fisiológicas.

Citando o calor e a cavitação, geralmente considerados os dois mecanismos mais importantes, que podem ser benéficos ou provocar danos nos tecidos biológicos estimulados.

Independente do tipo de mecanismo de interação que está agindo no tecido biológico estudado, o objetivo principal tem sido estabelecer limiares para a intensidade ultra-sônica, atingindo seu efeito desejado sem causar danos no tecido biológico estudado. (FERRARI, 1987),

Estudos indicam que as altas freqüências são lesivas e podem danificar tecidos e células quando a intensidade utilizada ultrapassa o limiar de $100 \mathrm{~mW} / \mathrm{cm}^{2}$ (HILL, 1972),

Sendo assim este mesmo autor considerou o limiar de $100 \mathrm{~mW} / \mathrm{cm}^{2}$ de intensidade como não lesivo para os tecidos biológicos, com referência especial a desnaturação do colágeno.

Os mecanismos físicos envolvidos na terapêutica do ultra-som que induzem respostas clinicamente significantes sobre as células, tecidos, órgãos e organismo são classificados como mecanismos térmicos e não térmicos. (DYSON, 1987).

Esses mecanismos e seus subseqüentes efeitos estão diretamente relacionados com os parâmetros físicos do ultra-som, com o tempo e a técnica de aplicação.

Com a constatação dos efeitos lesivos provocados pelas altas intensidades, muitos autores têm utilizado intensidades acústicas mais baixas na estimulação ultra-sônica.

\subsection{8 - Mecanismo Térmico}

Quando uma onda ultra-sônica atravessa um meio, tem sua intensidade progressiva reduzida em função da distância percorrida. 
Um dos fatores que contribuem para esta diminuição é a absorção da energia ultra-sônica, que provoca a elevação local da temperatura. (WELLS, 1977),

Nos tecidos biológicos não calcificados, a taxa de absorção do ultra-som pulsado, e conseqüentemente o coeficiente de atenuação da sua intensidade, aumentam com o aumento da freqüência da onda. (HILL, 1982).

As atribuições mais comuns ao Ultra-som é redução de dor com o aumento do aquecimento e aumento da extensibilidade de tecido mole, sendo que a variação da temperatura é reduzida proporcionalmente em razão do pulso, porém o seu aquecimento não é eliminado. (BAKER et al., 2001).

Embora o uso terapêutico do ultra-som pulsado se baseia, pelo menos em parte, no seu efeito de aquecimento, os resultados experimentais têm demonstrado que este fator, isoladamente, não deve ser responsável pelo estimulo aos processos de reparo e regeneração de tecidos. (DYSON, 1987).

Com os parâmetros do feixe ultra-sônico otimizado para o uso terapêutico, com baixa intensidade e baixa freqüência, o aumento local de temperatura é da ordem de centésimos de grau até pouco mais de $1^{\circ} \mathrm{C}$, sugerindo a participação de mecanismos não-térmicos na ação biológica do ultra-som pulsado. (DYSON e COLS, 1968, 1976, DYSON e SUCKLING, 1978, ALBERTIN, 1983, CARDOSO, 1985).

Estas intensidades são muito baixas para provocarem um aumento significativo na temperatura, fato que indica que outros mecanismos que não os térmicos estão envolvidos na interação do ultra-som com o tecido biológico $\quad E$ dentre os mecanismos não-térmicos que produzem efeitos nos tecidos biológicos podem citar o mecanismo cavitacional.

Cavitacional (Cavitação) é o processo de formação, crescimento e pulsação de cavidades (bolhas) cheias de gás, que pode ocorrer quando um feixe de ondas ultra-sônicas atravessa o tecido biológico, os fluídos orgânicos ou mesmo uma suspensão de células. (FRIZZEL; DUNN, 1984).

As bolhas assim formadas podem permanecer intactas por muitos ciclos (cavitação estável) ou entrar em colapso violento, causando pulsos de forte pressão e elevando a temperatura local (cavitação transitória). (WELLS, 1977).

Esta formação de bolhas de gás nos tecidos é resultante da vibração ultrasônica e tem evidências de ocorrência em doses cirúrgicas, como na Litotripsia, tornando-se difícil utilizar as doses terapêuticas. 
Acredita-se que a cavitação deve ser estudada próxima de cavidades cheias de ar, como o pulmão e o intestino. (BAKER et al., 2001).

O colapso das bolhas na cavitação transitória libera energia que pode romper ligações moleculares, provocar a decomposição térmica da água e a produção de radicais livres altamente reativos, causando alterações químicas indesejáveis e a lesão no tecido adjacente. (APFEL, 1982),

Não existe comprovação de que ocorram os efeitos deletérios da cavitação in vivo, em tecidos tratados com níveis terapêuticos de ultra-som de baixa intensidade. (HILL, 1972; DYSON; SUCKLING, 1978).

A cavitação estável se dá com intensidade acústica menor que aquelas necessárias para provocar a cavitação transitória. (WELLS, 1977),

As bolhas oscilam gerando um fluxo acústico ao seu redor, com efeitos consideravelmente menos destrutivos. (APFEL, 1982).

Este é, provavelmente, um dos mecanismos envolvidos na promoção dos efeitos terapêuticos do ultra-som pulsado, com experimentos realizados com cultura de fibroblastos mostra que a estimulação a níveis terapêuticos, portanto menores que aqueles que causam lise celular, estimulando a síntese protéica. (MOTIMER; DYSON, 1988),

Há evidências experimentais consideráveis de que níveis terapêuticos de ultra-som podem induzir a cavitação estável "in vivo", (TER HAAR, 1982), mas seus efeitos ainda não estão bem estabelecidos.

Entretanto, sabe-se que a cavitação estável "in vitro" pode produzir efeitos irreversíveis em suspensão celular, como a ruptura de membranas e de macromoléculas, desnaturação de enzimas, etc., dependendo dos parâmetros usados. (LEITE, 1989).

A intensidade limiar a partir do qual pode ocorrer cavitação foi determinada em meio aquoso por HILL (1971), em 0,1 W/cm², e "in vivo" por TER HAAR (1982), em $0,2 \mathrm{~W} / \mathrm{cm}^{2}$.

\subsection{9 - Fluxo e Microfluxo Acústico}

A propagação da onda acústica provoca, nos fluidos dos tecidos biológicos ou de suspensões de células, movimentos unidirecionais denominados fluxo acústico e microfluxo, referindo-se aos movimentos circulares produzidos no meio por bolhas 
que oscilam sob influência do campo acústico.(DYSON; NYBORG, 1982).

Esses movimentos originam forças e tensões que podem modificar a posição das células ou das partículas intra e extras celulares, ou mesmo danificar as macromoléculas e células. (WELLS, 1977; NYBORG, 1982).

Experimentos realizados com mastócitos revelaram que a insonação utilizados com níveis terapêuticos provoca alterações na membrana celular, aumentando assim o influxo de íons cálcio. (DYSON, 1985)

Os autores apoiaram essa observação, sugerindo que 0 microfluxo intracelular, provocado pelo ultra-som pulsado, aumentaria a permeabilidade da membrana daquelas organelas, levando ao aumento da atividade hidrolítica intracelular e conseqüentemente ao aumento da disponibilidade de precursores para a síntese protéica.

\subsubsection{0 - Piezeletricidade}

Este fenômeno, denominado, piezeletricidade, foi descoberto por Pierre Curie no ano de 1880. (MASON, 1981), sendo definida como uma propriedade física segundo a qual alguns materiais quando deformados por uma tensão mecânica, desenvolvem, carga elétrica superficiais e vice e versa, colocando um material piezelétrico sob um campo elétrico, as cargas elétricas interagem com o mesmo e o material exibe deformações mecânicas. (OKUNO, CALDAS \& CHOW, 1986).

(FUKADA; YASUDA, 1957), foram os primeiros a descreverem a piezeletricidade em um tecido biológico "o osso", observando os efeitos direto e inverso no osso, mostrando que ao sofrer deformações mecânicas, cargas elétricas são formadas na face oposta do osso, sendo este efeito devido à molécula de colágeno.

A piezeletricidade continuou a despertar interesse da comunidade científica, procurando estabelecer uma relação entre eletricidade e os mecanismos de crescimento e regeneração.

Hoje se sabe que a piezeletricidade é uma propriedade natural de certos cristais e substâncias cristalizadas que apresentam, a capacidade de reagir diferentemente de acordo com a direção de propagação de um fenômeno físico sobre si, como a luz, o calor, etc. 
O tratamento de fraturas ósseas com ultra-som pulsado baseia-se na piezeletricidade do tecido ósseo (DUARTE, 1977).

A interação do ultra-som pulsado de baixa intensidade com o tecido ósseo em processo de reparação tem sido atribuída a um mecanismo de natureza piezelétrico (ALBERTIN, 1983; XAVIER e DUARTE, 1983; SILVA, 1987).

O ultra-som pulsado de baixa intensidade atinge a superfície do osso em uma sucessão de pulsos que levam ao desenvolvimento de cargas elétricas superficiais.

Tem-se, a conversão de energia mecânica em energia elétrica quando a superfície óssea, sob o impacto mecânico das ondas ultra-sônicas, sofre uma polarização elétrica.

A terapia de fraturas e calos ósseos com ultra-som pulsado resume-se, pois, em determinar o desenvolvimento de cargas elétricas no sítio da lesão, estabelecendo uma corrente que estimula a proliferação das células ósseas e seu metabolismo (ALBERTIN, 1983; XAVIER e DUARTE, 1983).

(SILVA, 1987), demonstrou teoricamente que a aplicação de um campo acústico em tecido ósseo produz um campo elétrico ao nível da membrana celular e pressupõe que este efeito deve ocorrer em todos os tecidos que contém colágeno, o que pode ser um dos mecanismos para o efeito do ultra-som sobre o osso e a pele.

\subsubsection{1 - Efeitos do Ultra-Som nas diferentes fases do reparo tecidual}

Fase inflamatória - O Ultra-Som Pulsado de Baixa Intensidade interage com os macrófagos, mastócitos e neutrófilos, acelerando a resolução normal da inflamação. Este aumento na velocidade ocorre devido a suave movimentação do líquido intersticial que pode aumentar a taxa de fagocitose, o movimento de partículas e células, aumentando a liberação de mediadores químicos do processo inflamatório como a histamina e a serotonina. É importante notar que o Ultra-Som tem ação próinflamatória e não antiinflamatória (LEFAUCHER; SÉBILLE, 1995; KOKUBU et al., 1999).

Fase proliferativa - Tecidos submetidos ao Ultra-Som Pulsado de Baixa Intensidade apresentam um aumento significativo no número de células no leito da ferida. Os fibroblastos podem ser estimulados a produzir um aumento na síntese de colágeno devido ao aumento na permeabilidade da membrana celular. O Ultra-Som pode também estimular a angiogênese, e o crescimento de capilares no leito da 
ferida, estimulando assim a contração da ferida (DYSON, 1987; SILVA, 1987; HUME \& KALIMO, 1992; TIS, et al., 2001)

Fase de remodelamento - O Ultra-Som Pulsado de Baixa Intensidade tem a capacidade de interagir com o colágeno aumentando sua extensibilidade, a resistência tênsil da cicatriz também pode ser aumentada quando é submetida ao estímulo, sendo também responsável pela deposição do colágeno com uma arquitetura tridimensional semelhante a da pele não lesionada (HILL, 1972; DYSON, 1987)

Pode-se dizer, ou chegar a esta conclusão do que foi exposto anteriormente, que o estímulo de tecidos biológicos com ultra-som pulsado de baixa intensidade estimula:

- A proliferação fibrovascular e, conseqüentemente, a formação de tecido de granulação;

- A proliferação de epitélio pavimentoso estratificado, levando a epitelização de lesões ulceradas;

- O aumento da síntese de RNA ribossômico, por células da medula óssea;

- O aumento da síntese protéica;

- A proliferação, diferenciação e aumento da atividade metabólica de células ósseas, acelerando a consolidação de fraturas.

\subsubsection{2 - Lise ou Morte Celular}

(CARDOSO, 1985), em estudos de cromossomos de células da medula óssea expostas in vivo ao ultra-som pulsado de baixa intensidade, usado para estimulo ao reparo ósseo, apresentaram evidências de danos do DNA, nas regiões organizadoras de nucléolos (RONs). Não foram, no entanto, as aberrações cromossômicas clássicas descritas em metáfases de células da medula óssea. Essa observação sugere que as RONs, são as regiões mais frágeis dos cromossomos, ou então que as células que sofreram lesões mais intensas tenham sido eliminadas, escapando à observação posterior. Baseada nesta última possibilidade, (CARDOSO, 1985), sugeriu que a lise ou a morte de células que apresentam lesões cromossômicas, causadas pela 
insonação, poderia representar mais um mecanismo responsável pela ação estimulatória do ultra-som pulsado. A morte celular levaria à liberação de fatores de crescimento com ação mitogênica, favorecendo o reparo do tecido.

Este mesmo autor apresentou também evidência morfológica de que o estímulo ultra-sônico induz aumento da síntese de RNA ribossômico, outro fator provavelmente relacionado com sua ação estimuladora de crescimento e reparo de tecido ósseo.

\section{2 - Alguns Aspectos Estruturais dos Órgãos Reprodutores de Ratos Machos}

A puberdade está definida no macho como a época em que atinge a capacidade para fecundar uma fêmea. Isto significa que o indivíduo púbere deve ter a capacidade de produzir número suficiente de espermatozóides fecundantes (GONZÁLEZ, 2002).

A instalação do período caracterizado como puberdade está relacionado a vários fatores:

a) Níveis hormonais de testosterona e de gonadotrofinas secretadas durante 0 período pré-puberal;

b) Raça;

c) Nutrição;

d) Fator geográfico.

Estudos em ratos, como animal modelo de experimentação, mostram que existem receptores para Hormônio Liberador de Gonadotrofinas $(G n R H)$, na adeno hipófise desde o $16^{\circ}$ dia de gestação, sugerindo um papel ativo deste hormônio no controle da função hipofisária.

As evidências indicam que existe na maioria dos animais a produção precoce de LH na hipófise fetal, por outro lado, existem receptores para LH no testículo fetal, os quais aumentam progressivamente durante a gestação até atingir níveis máximos no momento do nascimento.

$\mathrm{O}$ aumento do número de receptores de LH no testículo coincide com o aumento no número de células de Leydig e o maior conteúdo testicular de 
testosterona.

Entretanto, a testosterona diminui no momento do nascimento, o que leva a pensar que a testosterona fetal tenha mais a ver com a ontogênese e a diferenciação sexual dos órgãos genitais.

Esses fatos levam a crer que os hormônios FSH e LH têm função de controle no desenvolvimento testicular desde antes do nascimento.

Depois do nascimento, gradualmente os níveis de $\mathrm{GnRH}$, aumentam com a idade, bem como o conteúdo hipofisário de LH e de FSH.

Com o início da puberdade, ocorre um pronunciado aumento de testosterona, que está correlacionado com o padrão de secreção de $\mathrm{LH}$, hormônio este que estimula a secreção direta de testosterona pelas células de Leydig.

Os eventos primários que estabelecem o início da puberdade são originados no SNC e concorrem para causar uma alteração no padrão de secreção hipotalâmica de $\mathrm{GnRH}$. Estes fatores hormonais e possivelmente um fator nervoso direto influenciam no crescimento e na maturação testicular.

Com a puberdade inicia-se um padrão pulsátil de secreção de $\mathrm{GnRH}$, ocorrendo um pico de secreção de gonadotrofinas durante o período pós-puberal.

O evento mais significativo na puberdade é a mudança na androgênese que tem a produção de testosterona como principal andrógeno. À medida que animal amadurece, os testículos ficam mais sensíveis à ação estimulatória das gonadotrofinas, principalmente pelo aumento na secreção do $\mathrm{FSH}$.

Tanto testosterona como gonadotrofinas, proporcionam o principal estímulo para o início da espermatogênese. O aumento de testosterona também produz alterações típicas da puberdade sobre os órgãos genitais.

A testosterona aumenta progressivamente até atingir os níveis do adulto, obedecendo assim à estimulação de LH de forma que a cada pulso de LH segue-se um aumento do teor de testosterona, a medida em que a puberdade se instala definitivamente.

Uma explicação alternativa para o início da puberdade, seria de um evento independente da gônada, originado por um mecanismo central que ativaria a liberação de $\mathrm{GnRH}$.

E uma noção já aceita os centros hipotalâmicos produtores de $\mathrm{GnRH}$ proporcionam o estímulo inicial para o início da "maturação sexual".

Os neurônios da adeno hipófise produtores de $\mathrm{GnRH}$ quando a puberdade 
se aproxima apresentam alterações morfológicas as quais estariam ligadas ao controle central de início da puberdade.

\subsection{1 - Sistema Genital Masculino}

O sistema genital masculino consta de órgãos produtores dos espermatozóides, células sexuais, do andrógeno, testosterona, testículos e seus envoltórios; vias espermáticas, epidídimo e ducto deferente; a uretra e suas glândulas anexas, e o órgão da copula, o pênis.

$\mathrm{Na}$ maioria das espécies animais, os testículos estão fora do abdômen, na bolsa escrotal, nas aves e em outros animais os testículos têm localização intraabdominal. Os testículos migram da cavidade abdominal para a bolsa escrotal mediante ação do gubernaculum testis, antes do nascimento na maioria das espécies. A época de descida dos testículos varia com a espécie, e geralmente este descenso ocorre durante a gestação até quando se completa o nascimento.

Quando os testículos não migram ocorre o criptorquidismo, que se caracteriza pela parada da migração do testículo no seu trajeto normal que pode ser uni ou bilateral, devido a causas genéticas.

Os animais que apresentam este problema são inférteis ou sub-férteis, devido à temperatura imprópria para a espermatogênese fora da cavidade escrotal. Mas a libido pode estar aumentada, porque depende da androgênese.

O escroto tem estrutura semelhante à da pele, porém é altamente especializada para manter a temperatura dos testículos. A termo-regulação do testículo é necessária para ocorrer à espermatogênese, sendo controlada por componentes dos envoltórios dos testículos, pela circulação arterial e principalmente pelo músculo dartos.

a) Os músculos cremáster (estriado) e o músculo dartos (liso) participam do mecanismo regulatório.

b) As inúmeras glândulas sudoríparas do escroto.

A artéria testicular no rato é extensamente enrolada, especialmente fora do canal inguinal, as veias abandonam o testículo por sua margem dorsal considerada como seu hilo para formar o plexo pampiniforme (devido à disposição das várias 
veias enredadas como galhos de uma videira). Há anastomoses artério-venosas que fazem com que aproximadamente $40 \%$ do sangue da artéria retorne ao sistema venoso.

As vias espermáticas são condutos com funções de armazenamento, nutrição, maturação e transporte do semem até a uretra. Compreende túbulos retos, rede testicular, os dutulos eferentes, epidídimo, dutulos deferentes e uretra.

A rede testicular é uma complicada rede tubular em seqüência aos túbulos retos cujos canais se intercomunicam e permitem o transporte dos espermatozóides e fluídos em direção ao epidídimo. A união entre a rede testicular e o epidídimo é feito mediante os dutulos eferentes, os quais têm dois tipos de células, as principais e as ciliadas. Suas funções incluem transporte de espermatozóides, secreção de substâncias nutridoras e absorção de fluídos com função de nutrir os espermatozóides.

O epidídimo é um tubo altamente convoluto de considerável comprimento que se dobra sobre si mesmo. Colado junto à margem dorsal do testículo, estende-se do pólo antero superior ao inferior deste órgão, mantendo-se firmemente unido à túnica albugínea mediante ligamentos. O epidídimo leva os espermatozóides dos dutos eferentes para os dutos deferentes.

O epidídimo consta de três partes

1. Cabeça, no pólo antero superior do testículo;

2. Corpo, que se relaciona com a margem a dorsal do testículo;

3. Cauda, no pólo postero inferior, área considerada, no homem, como o reservatório de espermatozóides.

Uma proposta alternativa divide o epidídimo em regiões inicial, média e terminal.

As duas classificações não necessariamente coincidem. O epidídimo tem funções secretórias que visam manter a viabilidade do espermatozóide durante 0 seu armazenamento.

O epitélio ciliado do epidídimo e a capacidade contrátil de sua parede permitem o transporte dos espermatozóides até o reservatório. 
A maturação final dos espermatozóides ocorre no epidídimo, processo que inclui mudanças morfológicas e bioquímicas a fim de capacitar os espermatozóides para a fecundação.

Os segmentos inicial e médio estão comprometidos com a maturação espermática, enquanto que o segmento terminal (cauda) tem maior capacidade de armazenamento, sendo considerado como reservatório. A cabeça e o corpo do epidídimo têm capacidade para absorverem fluídos. A passagem dos espermatozóides pelo epidídimo dura de dez a doze dias.

A cauda do epidídimo continua-se, sem limites nítidos com os dutos deferentes, que entram na cavidade abdominal como um componente do cordão espermático e desemboca no colículo seminal na uretra pélvica. Os dutulos deferentes tem uma parede muscular espessa o que o faz muito nítido ao tacto, dentro do cordão, tendo um comprimento aproximado de $45 \mathrm{~cm}$ no homem e de 6 $\mathrm{cm}$ no rato.

As glândulas acessórias são em geral do tipo túbulo alveolar cuja secreção desemboca na uretra misturando-se aos espermatozóides no momento da ejaculação, para constituir o sêmen e fornecer meios necessários para o transporte e a nutrição dos espermatozóides e neutralizar o pH vaginal.

Compreendem: as vesículas seminais (glândulas vesiculares), a próstata, as glândulas bulbo uretrais (glândulas de Cowper) e as glândulas uretrais (glândulas de Littre).

De todos os órgãos reprodutivos masculinos, as glândulas acessórias são as que têm maior variação entre as diferentes espécies em termos de morfologia, biologia e função. Não somente varia o tipo e a forma da glândula, mas o volume, as características e a composição bioquímica, de suas secreções. Existe uma considerável variação entre as espécies de mamíferos em relação ao número de glândulas acessórias.

A única glândula acessória presente em todos os mamíferos é a próstata, exceto carnívoros e cetáceos, os demais mamíferos possuem glândulas bulbo uretrais.

O rato possui todas as principais glândulas acessórias, tendo ainda glândulas prepuciais e glândulas coaguladoras, as quais são encarregadas de promover temporariamente a coagulação do ejaculado. As duas vesículas seminais são chamadas assim devido a um conceito inicial errado, de que eram os reservatórios 
de espermatozóides. São arranjadas em múltiplos lóbulos e com um sistema ramificado de dutos, parecendo ao corte com um favo de mel.

As duas glândulas bulbo uretrais ou glândulas de Cowper são tubulares, multi-lobulares ou túbulos-alveolares situadas ou localizadas lateralmente à uretra pélvica, tendo sua secreção mucosa conduzida até a luz da uretra por finos dutos.

A diferenciação embrionária das glândulas acessórias bem como seu crescimento é andrógeno dependente. As glândulas acessórias possuem epitélio secretor, cuja superfície é aumentada pela disposição em vilosidades.

O conjunto de secreções da próstata, das glândulas bulbos-uretrais e das vesículas seminais compõem o semem, o qual contém também fluído do epidídimo, e espermatozóides.

O sêmen da maioria dos mamíferos é relativamente diluído devido à grande proporção da secreção das glândulas acessórias. A principal substância do semem é a água, cuja função hidrodinâmica garanta que o sêmen seja efetivamente ejaculado.

Existe variação na composição química do semem, embora alguma das suas substâncias especifica apresentam funções pouco conhecidas, como inúmeras substâncias do plasma sanguíneo não têm necessariamente significância fisiológica para as células sanguíneas (GONZÁLEZ, 2002).

A alta quantidade de frutose secretada pelas vesículas seminais fornece energia para o metabolismo do espermatozóide, as proteínas servem para a sobrevivência do espermatozóide, exercendo também a função tampão para neutralizar o $\mathrm{pH}$ ácido das secreções vaginais.A prostaglandina do plasma seminal pode contribuir para facilitar o transporte dos espermatozóides até o útero e tubos.

Os espermatozóides são capazes de fertilizar sem entrar em contato com as secreções das glândulas acessórias, mas, no entanto, as secreções seminais otimizam as condições de motilidade, sobrevivência e transporte dos espermatozóides, tanto no trato reprodutivo masculino, quanto no feminino, capacitando-os à fecundação.

Em todos os mamíferos, os testículos são órgãos pares ovóides encapsulados, compostos de túbulos seminíferos enovelados e justapostos e os espaços deixados entre eles localiza-se o tecido intersticial.

A unidade estrutural e funcional dos testículos são os túbulos seminíferos, contendo o epitélio germinativo cujos componentes celulares podem ser dispostos 
em três compartimentos (GONZÁLEZ, 2002).

O "compartimento adluminal" compreende aquela parte do epitélio germinativo onde se encontram as células de Sertoli, localizados junto à membrana tubular as quais formam uma estreita união entre elas e, submersas entre estas se dispõem células germinativas em diferentes estadios de desenvolvimento (espermatogônias, espermatócitos primários. Os espermatócitos secundários e as espermátides estão sempre mais próximas à luz dos túbulos seminíferos onde também se encontram os espermatozóides jovens e ou maduros).

a) Os "compartimentos basais" constituem-se de membranas ditas tubulares de estrutura conjuntivos elásticos as quais separam o compartimento adluminal de qualquer contato com o sangue (barreira hematoespermática). Septos conjuntivos separam túbulos em lóbulos cujas paredes são dotadas de células mio epiteliais contendo um ou mais túbulos seminíferos enovelados.

b) O "compartimento intersticial" é aquele constituído pelos espaços compreendidos entre as paredes dos túbulos seminíferos dispostos em voltas, os quais contêm as células intersticiais de Leydig, produtoras de testosterona, esses compartimentos contêm ainda vasos sanguíneos e linfáticos, bem como nervos do parênquima testicular. Também contém outras células como mastócitos e macrófagos, estes últimos têm receptores para FSH produzindo lactato e outros metabólitos.

Os túbulos seminíferos não são penetrados por vasos sanguíneos ou linfáticos, os quais se restringem ao tecido intersticial. As células espermatogêneticas ficam isoladas por assim chamada barreira hematoespermática constituída pelas paredes tubulares contendo as células mio epiteliais, as quais são responsáveis pelo movimento peristáltico dos túbulos.

\subsection{2 - As Células de Sertoli}

As células de Sertoli, originalmente descritas por (Enrico Sertoli, 1865), são os componentes celulares considerados não germinativos do epitélio seminífero. Estas células ocupam o espaço entre a membrana basal e a luz tubular, ficando 
intimamente relacionados entre células germinativas dispostas em grupos dispostos entre elas.

Algumas características morfológicas dessas células, relacionadas com as suas funções são as seguintes:

a) Contêm numerosos lisossomos e vacúolos autofágicos que participam na fagocitose e digestão das células germinativas degeneradas;

b) Possuem grande quantidade de retículo endoplasmático liso, revelando atividade secretória de esteróides;

c) Apresentam alterações morfológicas no seu citoplasma ao longo do túbulo, revelando sua participação na espermiogênese;

d) Existem uniões especializadas entre as células de Sertoli vizinhas as quais mantém a integridade estrutural do túbulo seminífero e constituem o componente epitelial da barreira hemato-espermática. Substâncias presentes no compartimento basal só podem ir aos compartimentos adluminal e luminal passando através das células de Sertoli.

Entre funções das células de Sertoli estão as seguintes:

a) Manutenção da barreira hemato-espermática e da secreção do fluído tubular;

b) Secreção de mais de 100 proteínas. As células de Sertoli são sensíveis a FSH e a testosterona e secretam, entre outras, a proteína transportadora de andrógenos (ABP), a qual é estruturalmente similar a SHBG (globulina transportadora de hormônios sexuais), produzida no fígado.

Oitenta por cento da secreção de ABP vai para o lúmen e vinte por cento vai para o plasma sanguíneo. Esta proteína está imunologicamente relacionada com a globulina transportadora de estradiol. A principal função da ABP é o transporte extracelular de testosterona, para manter altos teores desse hormônio nos túbulos seminíferos e no epidídimo, visto que a concentração sanguínea de testosterona é insuficiente para manter suas funções nessas regiões. 
Outras proteínas secretadas pelas células de Sertoli incluem a transferrina e a ceruloplasmina, proteínas transportadoras de ferro e cobre, minerais necessários para o desenvolvimento das células germinativas. E a produção destas proteínas é estimulada por $\mathrm{FSH}$, testosterona e retinol.

c) Secreção de ativadores de plasminogênio, enzimas cuja atividade é estimulada por $\mathrm{FSH}$, estando envolvidas na reestruturação tissular na migração celular, facilitando a liberação das espermátides maduras e a migração das células germinativas do comportamento basal para 0 compartimento adluminal;

d) Secreção de hormônios, a maioria tendo efeitos autócrinos ou parácrinos, tais como a inibina e alguns esteróides. Embora as células de Sertoli produzam pouco andrógeno e contribuam muito pouco para o pool de andrógenos sanguíneos, alguns são importantes para as funções dos túbulos seminíferos, da rete testis e do epidídimo.

O FSH regula a secreção de proteínas nas células de Sertoli, bem como o metabolismo energético, pois estimulam a captação de glicose, a produção de lactato e a atividade do glicogênio fosforilase.

Também o FSH estimula a síntese de glicoproteínas de superfície e tem profundo efeito na proliferação das próprias células de Sertoli. O principal efeito da testosterona é sobre a síntese de proteínas. O FSH e a testosterona atuam sinergicamente para induzir a síntese de receptores de FSH nas células de Sertoli.

As vitaminas $A, D$ e E são estimulatórias da atividade das células de Sertoli.

Deficiências de vitamina $A$ causam diminuição da fertilidade a ponto de causar azoospermia. A vitamina $E$ influi na secreção de ABP.

As células intersticiais ou de Leydig, localizadas fora dos túbulos seminíferos, estão sob controle de LH secretam os andrógenos, dos quais o mais importante é a testosterona e seu produto biologicamente mais ativo, a 5-dihidrotestosterona (DHT).

E a biossíntese da testosterona é realizada no retículo endoplasmático da célula de Leydig.

A conversão a DHT é realizada nos órgãos-alvo da testosterona (próstata, 
pele, folículos pilosos e cérebro) pela 5 alfa redutase, que requer NADPH como coenzima, e a afinidade do receptor androgénico é maior pela DHT do que pela testosterona. A fonte primária dos andrógenos é o depósito de colesterol existente nas gotas lipídicas do citoplasma das células de Leydig. O colesterol armazenado em forma de éster é hidrolisado pela enzima colesterol-éster hidrolase, estimulada pelo LH. A via de síntese dos andrógenos envolve a conversão do colesterol até testosterona. A via inicia com a conversão do colesterol em pregnenolona, o que ocorre na mitocôndria, sendo que esta reação é realizada por enzimas do grupo dos citocromos P450.

\subsection{3 - Regulação da Síntese de Testosterona}

O controle mais importante da síntese de andrógenos no testículo é feito pelo LH, o receptor deste LH está acoplado à enzima adenilciclase mediante um sistema GTP estimulatória, e a regulação hipotalâmica da secreção de andrógenos está determinada pela secreção de GnRH.

Fatores externos, como a luz e ou estímulos olfatórios ou visuais, podem aumentar a secreção de $\mathrm{GnRH}$ via sistema nervoso central, mediante neuroreceptores que incluem a dopamina, a norepinefrina e a serotonina.

A função secretora das células de Leydig é estimulada pela prolactina, favorecendo a síntese de receptores para LH (efeito oposto ao da fêmea) e possivelmente melhorando a atividade enzimática da síntese de testosterona a partir do colesterol.

O FSH também parece favorecer a presença de receptores para LH nas células de Leydig.

O stress ocasiona aumento da secreção de $\mathrm{ACTH}$, o qual inibe a secreção de LH no macho, e, portanto de testosterona, desfavorecendo a espermatogênese e a libido.

Os glicocorticóides secretados pela ação do ACTH também tem ação inibitória direta sobre a secreção das gonadotrofinas.

Existe uma relação entre a atividade reprodutiva do macho e o funcionamento tireoidiano. Em machos hipotireoideos, seja por deficiência de iodo ou por ingestão de substâncias bociogênicas, é observada depressão da libido e da 
espermatogênese.

A taxa de secreção de testosterona está relacionada diretamente com o fluxo sanguíneo da artéria espermática, e a adrenalina diminui a concentração de testosterona plasmática, talvez por diminuir o fluxo sanguíneo ao testículo.

Por outro lado, a própria adrenalina estimula a secreção de testosterona quando se considera o volume sanguíneo.

O controle "down regulation" é considerado como um controle da secreção de testosterona, mediante a diminuição do número de receptores para $\mathrm{LH}$, quando ocorrem aumentos importantes desse hormônio.

A síntese de testosterona parece ter também um controle parácrino, pois os estrógenos sintetizados pelas células de Sertoli inibem a síntese de testosterona nas células de Leydig por inibir a enzima que cliva o colesterol, o citocromo P450.

\subsection{4 - Principais Ações dos Andrógenos}

A diferenciação da gônada por efeito do antígeno codificado pelo fator de determinação de testículo (diferenciação sexual), causando o início de produção de testosterona, a qual promove a diferenciação dos dutos internos (vaso deferente, vesículas seminais e epidídimo), a partir dos dutos de Wolff.

As células de Sertoli, por sua vez, produzem o hormônio anti-mulleriano $(\mathrm{AMH})$.

Os andrógenos juntamente com o FSH produzem a espermatogênese; também são responsáveis pelo desenvolvimento e manutenção dos órgãos sexuais secundários, desenvolvimentos de estruturas ornamentais nos machos de algumas espécies (crista, pigmentação sexual, crescimento de pêlo, chifres e o maior tamanho da musculatura esquelética).

Comportamento de combatividade e dominância no rebanho, efeitos anabólicos e promotores do crescimento esquelético e muscular, estímulo da libido, ereção e a ejaculação, redistribuição da gordura corporal, a maior concentração de eritrócitos e a maior taxa metabólica.

As células de Leydig também podem sintetizar estrógenos a partir da aromatização dos andrógenos.

As células de Sertoli também podem sintetizar estrógenos, especialmente antes da puberdade. 


\subsection{5 - Espermatogênese}

A espermatogênese é caracterizada por uma seqüência de associações de diferentes tipos celulares que ocorre no epitélio seminífero resultando na formação dos espermatozóides a partir das espermatogonias, que são responsáveis pela perpetuação da espermatogênese. Esta seqüência obedece a uma ordem rigorosa e se faz sob a forma de ondas espermatogenéticas as quais não tem a mesma duração em todos os animais. Em alguns mamíferos e aves a espermatogênese é sazonal, com interrupções temporárias.

A espermatogênese envolve uma replicação de células germinativas (espermiocitogenêse) até o aparecimento de células haplóides (espermátides) caracterizadas como meiose. As modificações morfológicas das espermátides (espermiogênese) levam à produção de espermatozóides maduros.

Os mais importantes eventos na espermatogênese são:

1. A renovação das espermatogonias em varias gerações, por multiplicação;

2. A duplicação, por repartição do número de cromossomos, que caracteriza a meiose, chamadas divisões reducionais;

3. A transformação de uma espermátide em uma complexa estrutura móbil (espermatozóide) após uma grande metamorfose (espermiogênese).

As células germinativas são as espermatogônias que, após a puberdade, se diferenciam em função de sua morfologia nuclear em três tipos: A, B e Intermediária, e a partir da linha primordial de espermatogônias são originadas, por multiplicação mitótica, em várias gerações. Algumas gerações de espermatogônias de reserva permanecem latentes e reproduzem-se em seqüências temporais e servem para perpetuar a produção de espermatozóides.

As espermatogônias tipo $A$ se multiplicam por mitose para dar sucessivamente as espermatogônias $B$, e intermediárias, sendo que as diferentes gerações de espermatogônias permanecem ligadas através de pontes intercelulares de 2 a $3 \mu \mathrm{m}$ de largura, separadas das células de Sertoli por espaços intercelulares de $0,2 \mu \mathrm{m}$. 
Das espermatogônias $B(2 n)$, originadas por mitose de espermatogônias A originam-se por sua vez os espermatócitos primários que por meiose e divisões reducionais originam os espermatócitos secundários que é a segunda divisão meiótica, os quais perdem contato com a membrana basal do epitélio seminífero e sofrem modificações morfo bioquímicas gerando as espermátides (n). O processo, até a produção das espermatides é chamado de espermiocitogênese.

$\mathrm{Na}$ meiose acontece recombinação homóloga (crossing over) entre os cromossomos dos espermatócitos.

Posteriormente, cada espermátide por transformação morfológica origina um espermatozóide, no processo conhecido por espermiogênese. Uma espermatogônia produzira dois espermatócitos, um espermatócito primário produzira quatro espermatozóides, e cada espermatócito secundário produzira duas espermátides.

Do núcleo da espermátide origina-se a cabeça do espermatozóide, que é recoberto pelo acrossoma, contendo grande variedade de enzimas lisossomais importantes na penetração da zona pelúcida do óvulo.

Mudanças do núcleo, tais como o deslocamento do centro para a periferia, condensação da cromatina e redução do volume nuclear, simultaneamente com mudanças acentuadas na cabeça do espermatozóide.

Um dos centríolos origina o centro cinético do espermatozóide, ao passo que o outro centríolo forma a cauda, evento de alta complexidade, que compreende; a formação do filamento axial, da peça intermediária, da peça principal e da bainha mitocondrial.

O filamento axial é uma estrutura similar aos cílios e flagelos com um axonema de nove túbulos pares periféricos e um par de túbulos centrais, todos formados por proteínas contráteis chamadas tubulina e dineína, que são similares a actina e miosina, unidas por pontes de nexina.

Os espermatozóides ainda imaturos (espermátides), são liberados à luz do túbulo pela atividade contrátil das células mio epitelial dos túbulos seminíferos no processo conhecido como espermiação.

No processo ficam os chamados corpos residuais, no citoplasma das células de Sertoli, remanescentes do complexo de Golgi e do retículo endoplasmático, sendo depois fagocitados pelas próprias células de Sertoli.

A espermatogênese é garantida pelo ambiente único existente no epitélio seminífero entre as células de Sertoli, que formam a barreira hemato espermática. 
As espermatogônias foram identificadas por Von Ebner em 1871, e o termo foi aplicado por Von La Valette St. George em 1876, pesquisador que também originou os nomes de espermatócito e espermátide. $O$ controle da espermatogênese é feito pela FSH e pela testosterona, e a ABP produzida nas células de Sertoli leva a testosterona até o local da espermatogênese (GONZÁLEZ, 2002).

\subsection{6 - Ciclo Espermatogenético}

A espermatogênese faz-se em ciclos caracterizados por associações repetitivas de células em rigorosa sequência, as repetições completas produzem as ondas espermatogenéticas.

Os ciclos espermatogenético ou ciclos do epitélio seminífero são associações celulares caracterizáveis à microscopia e se sucedem ao longo dos túbulos seminíferos. Associações celulares sucessivas cumprem um ciclo espermatogenético.

As associações celulares distintas e seqüentes constituem estadios, no homem são 06 as associações celulares, e no rato são 19 as associações celulares (estadios) caracterizando um ciclo. Cada associação tem tipos distintos de células germinativas em vários estágios evolutivos as quais são reconhecidos por diferenças morfológicas, histoquímicas ou topográficos, como estadios do ciclo.

A duração de um ciclo espermatogenético é o tempo transcorrido entre aparecimento sucessivo de uma dada associação celular, e os diferentes ciclos que estão transcorrendo ao longo dos túbulos, são identificáveis como estadios seqüenciais do ciclo, isto é, um espaço do túbulo com um estádio do ciclo é adjacente com os estádios que $o$ antecedem ou the seguem.

O repetição completo das seqüências de associações ao longo dos túbulos é conhecido como ondas espermatogênicas. Em um só túbulo podem existir até quinze ondas espermatogênicas completas. E a seqüência da ordem dos estadios do ciclo pode ser quebrada por reversão, onde é chamada de modulação.

\subsection{7 - O Espermatozóide}

No século XVII, Ham e Leeuwenhoek descreveram os espermatozóides, considerando-os como animalículos que possuíam todos os componentes de um ser 
adulto que só precisariam crescer durante a gestação.

Spallanzani, no século XVIII, demonstrou que era necessária a união do espermatozóide com o óvulo para obter um novo ser. O nome de espermatozóide é atribuído a Von Baer em 1827.

O espermatozóide esta composta de quatro partes, quais sejam, a cabeça, o colo, a peça intermediária e a cauda. É uma célula especializada cuja única função é fertilizar o óvulo, para o qual utiliza os movimentos autônomos de sua cauda.

A cabeça do espermatozóide tem forma oval na maioria dos mamíferos e alongada nas aves, estando constituída quase em sua totalidade pelo núcleo, que contém metade do genoma de uma célula somática ( $n$ ).

A cabeça está rodeada por um complexo de membranas que inclui as membranas plasmáticas e do aparelho de Golgi, formando uma estrutura diferenciada conhecida como acrossoma, cujo interior existem enzimas, e estas enzimas hidrolisam os mucopolissacarídeos da zona pelúcida e o cumulus oophorus do óvulo no momento da fertilização, após a reação do acrossoma.

O acrossoma cobre os $2 / 3$ anteriores da cabeça do espermatozóide, enquanto que outra estrutura da membrana, a cápsula pós-acrossómica, cobre o 1/3 posterior.

O estádio do espermatozóide é a porção que une a cabeça e a peça intermediária, contendo a gota citoplasmática, escasso resíduo de citoplasma, e o centríolo proximal, considerado como o centro cinético do espermatozóide, isto é, a unidade que regula os movimentos autônomos.

A peça intermediária é a estrutura que garante a motilidade do espermatozóide graças aos filamentos de tubulina-dineína, proteínas contráteis cuja disposição é similar á dos cílios e flagelos observada em alguns microorganismos.

A porção filamentosa da peça intermediária e da cauda é conhecida como axonema, e a peça intermediária também possui abundantes mitocôndrias que garantem a produção de energia necessária para a contração do axonema.

O centríolo distal forma o anel de Jensun, local que marca o limite da peça intermediária e a cauda.

A cauda do espermatozóide está composta de duas peças, a principal, que ocupa a maior parte da cauda, e o terminal, no extremo final.

A peça principal possui filamentos, os quais estão recobertos por uma bainha fibrosa, que confere estabilidade ao axonema da cauda. 
A peça terminal também possui os filamentos sem a bainha fibrosa, estando só recobertos pela membrana plasmática. E graças às contrações da peça intermediária e da cauda, o espermatozóide pode avançar progressivamente a uma velocidade de $100 \mu \mathrm{m} / \mathrm{s}$.

\subsection{8 - Metabolismo do Espermatozóide}

O espermatozóide é a única célula do organismo que possui duas características especiais, ter a capacidade de movimentos rápidos e de fertilizar, e para cumprir com estas funções, o espermatozóide exibe características bioquímicas especiais. A frutose é o principal açúcar do sêmen e o espermatozóide tem capacidade para realizar fructólise anaeróbica e produzir lactato e energia.

O espermatozóide também se utiliza glicose como substrato energético, porém a frutose está em maior quantidade no sêmen, apresentando $250 \mathrm{mg} / \mathrm{dl}$, comparado com $10 \mathrm{mg} / \mathrm{dl}$ de glicose, provavelmente para evitar que outras células possam competir pelo substrato energético com os espermatozóides.

A taxa de consumo de oxigênio do espermatozóide aumenta quando entra em contato com os fluídos genitais femininos, os quais são ricos em bicarbonato.

No espermatozóide aumenta a oxidação de lactato a piruvato e a entrada de acetil-CoA no ciclo de Krebs, para aumentar assim a produção de energia.

A transferência de oxigênio do sangue para o lúmen uterino é suficiente para criar uma tensão de oxigênio que mantém o metabolismo aeróbico do espermatozóide, especialmente durante o estro.

A maior parte dos lipídios do espermatozóide são fosfolipídios, principalmente lecitina (fosfatidil-colina) e plasmalogênios como o fosfatidal-colina. Quando há déficit dos substratos energéticos imediatos (frutose, lactato), os ácidos graxos dos plasmalogênios atuam como substrato da respiração do espermatozóide.

Existem menos fosfolipídios no espermatozóide ejaculado do que no espermatozóide testicular, levando a acreditar que o conteúdo desses compostos diminui quando o espermatozóide passa da cabeça para a cauda do epidídimo, fato possivelmente relacionado com a maturação espermática final.

Os fosfolipídios participam de vários eventos metabólicos do espermatozóide, tais como as mudanças químicas associadas com a maturação, o processo de capacitação espermática e a preservação da membrana plasmática, embora não se 
conheçam em muitos casos os mecanismos de ação.

A suscetibilidade dos espermatozóides ao choque térmico parece estar relacionada com a composição dos fosfolipídios. As mudanças morfo bioquímicas que ocorrem antes da reação do acrossomo e conferem maior motilidade ao espermatozóide, são consideradas como capacitação espermática.

Este é o processo de seleção dos melhores espermatozóides capazes de fertilizar o óvulo. As mudanças envolvem a capacidade da membrana do acrossomo.

Durante o armazenamento dos espermatozóides no epidídimo por inibidores enzimáticos, que mantêm os espermatozóides em estado latente até a ejaculação.

$E$ quando o espermatozóide entra em contato com as secreções do trato genital feminino, é ativado o processo de capacitação, cuja duração varia conforme a espécie, sendo na média de 4 a 6 horas.

Os estrógenos parecem estimular a capacitação espermática, enquanto que 0 progesterona a inibe.

O movimento flagelar constitui a maior demanda energética do espermatozóide, pois para a sua locomoção ele deve superar a ineficiência mecânica do flagelo, a resistência oferecida pelas secreções viscosas do trato e a resistência gerada pela aglomeração dos outros espermatozóides.

O ATP gerado nas mitocôndrias da peça intermediária se difunde ao longo da cauda, mediante um tipo de difusão molecular.

Os microtúbulos do axonema estão compostos pela tubulina, existe também uma proteína que une os pares de microtúbulos do axonema, a nexina, cuja função não está completamente esclarecida.

Os movimentos progressivos dos espermatozóides são do tipo ondulatório de trás para frente ao longo do flagelo empurrando o espermatozóide para adiante.

Estes movimentos correspondem a um deslocamento dos filamentos, isto é, as fibrilas do axonema não alteram seu comprimento, mas se deslocam umas sobre as outras, sem encurtamento.

Durante os movimentos, os braços da dineína, em cada par de túbulos formam uma ponte transitória com o par adjacente, envolvendo sucessivas uniões e desuniões facilitando pela hidrólise do ATP, similarmente ao que ocorre com a troponina na contração muscular, mas em geral esses agentes aumentam a motilidade do espermatozóide. 


\subsection{9 - Duração do Ciclo Espermatogenético}

No rato adulto, as fases mitóticas da espermatogênese, que culmina com a formação de espermatócitos I, tem a duração aproximada de treze dias. As divisões reducionais dos espermatócitos I, originando os espermatócitos II e finalmente as espermátides jovens, dura cerca de dezessete dias (espermiocitogênese).

A espermiogênese, por sua vez, dura cerca de vinte e três dias. O processo espermatogênico do rato adulto, portanto, requer aproximadamente cinqüenta e três dias para completar-se.

(HADDAD, 1992), identifica que a fase mitótica da espermiocitogênese na pré-puberdade tem a duração aproximadamente de sete dias.

\subsubsection{0 - Estádios Evolutivos da Espermatogênese}

O epitélio germinativo é constituído pelas células de Sertoli e as células que constituem a linhagem espermatogênica. Estas células dispõem-se em quatro ou oito camadas entre a membrana tubular e a luz dos túbulos seminíferos.

As células componentes do epitélio germinativo com exceção das células de Sertoli originam-se das espermatogonias (células fontes) que são as mais próximas à parede dos túbulos. As espermatogonias dividem-se em mitoses sucessivas e as células neo formadas podem assumir dois destinos; continua semelhante à célula mãe e sofrem novas mitoses para perpetuar a produção de espermatogonias ou param de se dividir transformando-se em espermatócitos I de primeira ordem. Os espermatócitos entram em meiose.

O processo de meiose termina com a primeira divisão reducional cuja Prófase é demorada caracterizando uma série de transformações do espermatócitos I até a fase de Diplóteno. A Prófase se faz em ondas ao longo dos túbulos e as células associadas são facilmente caracterizáveis.

Em 1952, Leblond e Clermont denominaram de "ciclo espermatogenético", a seqüência das associações baseada na maturação das espermátides e sua transformação em espermatozóides (espermiogênese).

Um ciclo completo é representado por uma sucessão de associações celulares constantes e em ordem bem definida e seqüente, desde a formação de uma dessas associações até reaparecimento da mesma associação, completando 
assim um ciclo.

Este termo usado por Leblond e Clermont tende a referir-se a um ciclo de células da linhagem espermatogenética, na realidade o termo designa um ciclo dos aspectos do túbulo seminífero, onde diversos tipos de associações celulares se sucedem em longas ondas caracterizando a longa fase da meiose após o aparecimento do espermatócito I.

Estes autores descreveram e caracterizaram essas associações dentro do ciclo espermatogenético relacionando-as aos estadios da espermiogênese, isto é, a seqüência de modificações morfológicas e principalmente histoquímicas das espermátides evoluindo morfológica e funcionalmente para espermatozóides correspondendo às associações celulares e seqüentes a essas modificações, o que Ihes permite caracterizar as etapas do ciclo espermatogenético.

A classificação proposta por Leblond e Clermont mostrou-se, precisa e segura na determinação das associações que compõem os estadios do ciclo espermatogenético.

Esta classificação baseia-se na espermiogênese identificada pelos Autores em 19 estadios, iniciando-se com o aparecimento de uma geração de espermátides (estádio 1 da espermiogênese) até à expulsão dos espermatozóides maduros, na luz dos túbulos seminíferos (estadio 19 da espermiogênese) e as associações das diferentes células desenvolvendo a prófase da meiose até o aparecimento da última divisão meiotica em correspondência a cada estadio da espermiogênese.

Quando da primeira divisão reducional, surge uma geração de espermátides que atinge o estádio 14 da espermiogênese, aparece, abaixo dela, uma nova geração de espermátides que inicia seu estádio 1 , quando a geração anterior está no seu estádio 15, estas duas gerações evoluem uma acima da outra até que a primeira seja expulsa na luz do túbulo seminífero, no estádio 19 da espermiogênese.

Como espermatozóides maduros estas variações de estádios da espermiogênese foram identificadas pelas modificações morfológicas e histoquímicas das espermátides evoluindo para espermatozóides maduros.

O epitélio germinativo abaixo das gerações de espermátides compõe-se de 14 associações celulares distintas, que constituem os 14 estadios do ciclo do epitélio germinativo. $\mathrm{O}$ ciclo do epitélio germinativo consiste em uma série completa dessas associações celulares. 
$\mathrm{Na}$ (Figura 3), está à representação de um ciclo espermatogenético segundo estabelecido por (DYM e CLERMONT, 1970) e universalmente aceita.

As gerações de espermátides cumprem a espermiogênese em 19 estadios identificados em algarismos arábicos, enquanto as correspondentes associações celulares constituem-se em 14 estadios do ciclo, numerados em algarismos romanos.

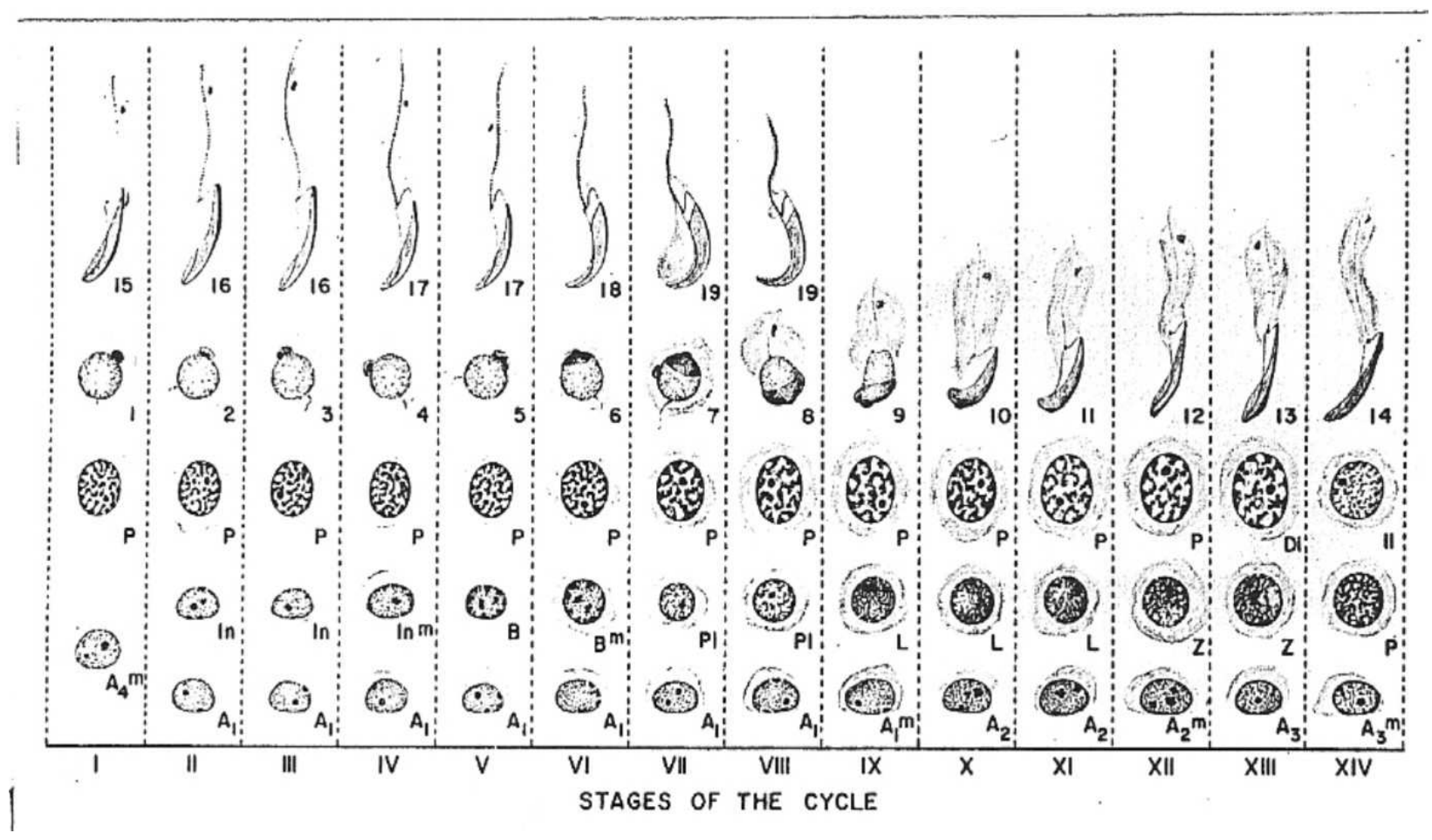

Figura 3- Estadio de I a XIV do ciclo do epitélio germinativo do rato. Espermatogonias tipos A (A1 a A4), intermediária (In) e B; mitoses de espermatogonias $(\mathrm{m})$; (prófase meiotica) espermatócitos primários, preleptoleno (P1), leptóteno (L); zigóteno (Z), paquíteno (P) e diplóteno (D); (após divisões reducionais) espermatócitos secundários (II); espermátides nos estadios 1 a 19 da espermiogênese (DYM E CLERMONT, 1970).

O ciclo tubular admitido por (FERREIRA, 1962), não considera para a caracterização dos diferentes estadios do ciclo espermatogenético, as variações histoquímicas que ocorrem na transformação das espermátides em espermatozóides. O ciclo tubular baseia-se nas modificações morfológicas das espermátides, as quais são perfeitamente caracterizáveis, na topografia das espermátides enquanto evoluem e as associações celulares correspondentes, com 
características das espermátides estabelecendo (catorze) estadios tubulares.

A vantagem desta classificação é que não há a necessidade de uma coloração histoquímica especial, podendo caracterizar-se os estadios tubulares com o uso de coloração habitual de Hemalumem e Eosina (H. E).

Portanto entre duas gerações de espermátides sucessivas, admite-se desta maneira, 14(catorze) estadios tubulares enumerados sucessivamente em algarismos romanos de I a XIV.

A classificação de Leblond e Clermont é muito precisa, mas requer uma coloração específica para identificar variações da espermiogênese histoquimicamente, não satisfazendo as necessidades de outros tipos de estudos.

A identificação dos estadios nos túbulos seminíferos na classificação de Leblond e Clermont é baseada inteiramente em pequenas modificações citológicas e histoquímicas das espermátides, tornando difícil à identificação dos estádios com essa metodologia, embora seja precisa.

Em função das dificuldades na precisão da identificação destes estádios (19), histoquimicamente, (FERREIRA, 1962), dividiu o ciclo tubular em 14 estadios baseando-se nas variações morfológicas das espermatides e a situação topográfica das mesmas concomitantes às gerações de células seqüentes do epitélio germinativo abaixo da geração das espermátides. A identificação dos estadios do ciclo espermatogenético preconizado por (FERREIRA, 1962), utilizando a seqüência das modificações morfológicas das espermátides na evolução para espermatozóides jovens e adultos foram as utilizadas nesta pesquisa.

A topografia e a morfologia das gerações de espermátides, relacionadas às associações de células situadas em concomitância às mesmas permitiu de maneira segura, caracterizar-se a dinâmica do ciclo espermatogenético em 14 (quatorze) estadios.

Esses critérios morfológicos permitem, com certeza identificar os estadios VII, VIII e XIV do ciclo.

Estadio VIl; espermatozóides jovens dispostos junto à luz do túbulo formando uma camada contínua.

Estadio VIII; caracterizado pela presença de espermatozóides (maduros) já na luz do túbulo e cujas caudas dispõem-se em vórtices, aptos a serem eliminados. 
Estadio XIV; caracterizado, pelo aparecimento das figuras das divisões reducionais, identificando o espermatócito I. 


\section{3 - Objetivo}

O objetivo principal deste trabalho foi o de avaliar a seqüência temporal do ciclo espermatogenético mediante caracterização histológica das associações celulares iniciais e finais do ciclo em testículos de ratos pré-púberes e adultos quando estimulados com o Ultra Som Pulsado de Baixa Intensidade, estimando-se também as áreas dos túbulos seminíferos bem como o peso dos testículos de ratos adultos. 


\section{4 - Material e Métodos}

\section{1 - Animais de Experimentação}

Utilizamos na presente investigação 40 ratos machos, da raça Wistar. Destes 20 ratos em idade pré-púbere, cujos pesos corporais variavam entre 75 a 85 gramas, e 20 ratos adultos, cujos pesos corporais variavam entre 220 a 260 gramas.

Os animais obtidos no biotério da UNESP de Araraquara SP foram separados em gaiolas apropriadas e mantidos por cerca de 48 horas no novo ambiente para adaptação. Durante o período de adaptação e experimental os animais receberam como alimentação, dieta balanceada Purina ${ }^{\circledR}$ e água à vontade, permanecendo em ciclo de claro e escuro por doze horas.

Os animais foram separados nos seguintes grupos experimentais:

\section{Grupo Experimental I}

Constou de 10 ratos pré-puberes, os quais foram estimulados com o Ultrasom pulsado durante dez dias consecutivos por 15 minutos.

\section{Grupo Experimental II}

Chamado de grupo controle constou de 10 ratos pré-púberes, os quais foram submetidos a uma estimulação fictícia diária durante dez dias por 15 minutos.

A manipulação e a estimulação fictícia destes animais foi idêntica à do grupo anterior. 


\section{Grupo Experimental III}

Chamado de grupo estimulado constou de 10 ratos sexualmente maduros, cujos testículos foram estimulados, durante 10 dias consecutivos por 15 minutos.

\section{Grupo Experimental IV}

Chamado de grupo controle constou de 10 de ratos machos sexualmente maduros, os quais, porém, foram submetidos a uma estimulação fictícia por tempo e duração equivalentes aos do grupo estimulado e manipulação equivalente. 


\section{2 - Equipamento gerador de Ultra-som e parâmetros usados}

O equipamento utilizado no experimento, foi um estimulador ultra-sônico, com circuito eletrônico e transdutor ultra-sônico projetados, elaborados e montados no Programa de Pós Graduação Interunidades Bioengenharia-USP, com sede na Escola de Engenharia da Universidade de São Paulo no Campus de São Carlos. (VALENTINI, 2006), fez a avaliação do campo acústico gerado pelo equipamento utilizado neste experimento.

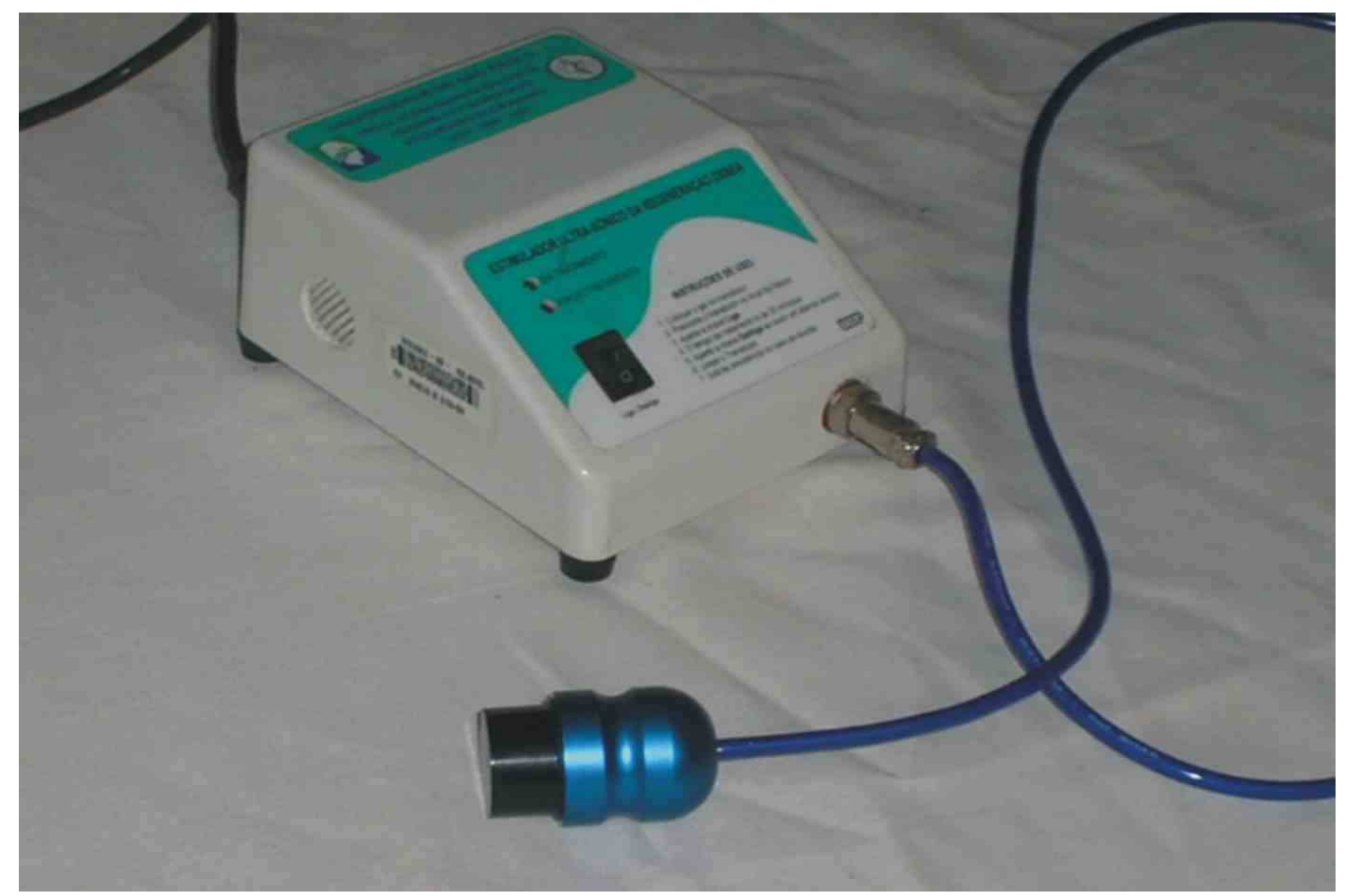

Figura 4: Fotografia do Aparelho de Ultra-som pulsátil de baixa intensidade, utilizado nesta investigação.

Durante todo o processo de sonicação, o Ultra-Som, operou com os parâmetros físicos relacionados abaixo: 
Tabela 2: Parâmetros do Ultra-Som utilizados no experimento.

\section{Parâmetros do Ultra-Som}

Forma de onda

Largura do pulso

Amplitude

Intensidade Acústica (SATA)

Freqüência de Repetição

Freqüência

Área do transdutor pulsada

$200 \mu \mathrm{s}$

$25 \mathrm{~V}$ (pico a pico)

$16 \mathrm{mw} / \mathrm{cm}^{2}$

$1 \mathrm{kHz}$

$1,5 \mathrm{MHz}$

$3,8 \mathrm{~cm}^{2}$

\section{3 - Estimulação ultra-sônica}

O transdutor ultra-sônico foi colocado na região mediana da bolsa escrotal dos animais com varredura homogênea após aplicação prévia de um gel hidrossolúvel acoplante. Tanto nos animais controle, quanto nos estimulados, foi utilizado o mesmo equipamento e procedimentos, diferindo apenas quanto ao estímulo do ultra-som, pois nos animais controles, houve uma simulação da aplicação com idênticas manobras, porém sem as emissões dos estímulos ultrasônicos.

A seqüência de figuras às paginas 61 e 62 , ilustram a técnica utilizada de acoplamento do transdutor ultra-sônico à bolsa escrotal. 


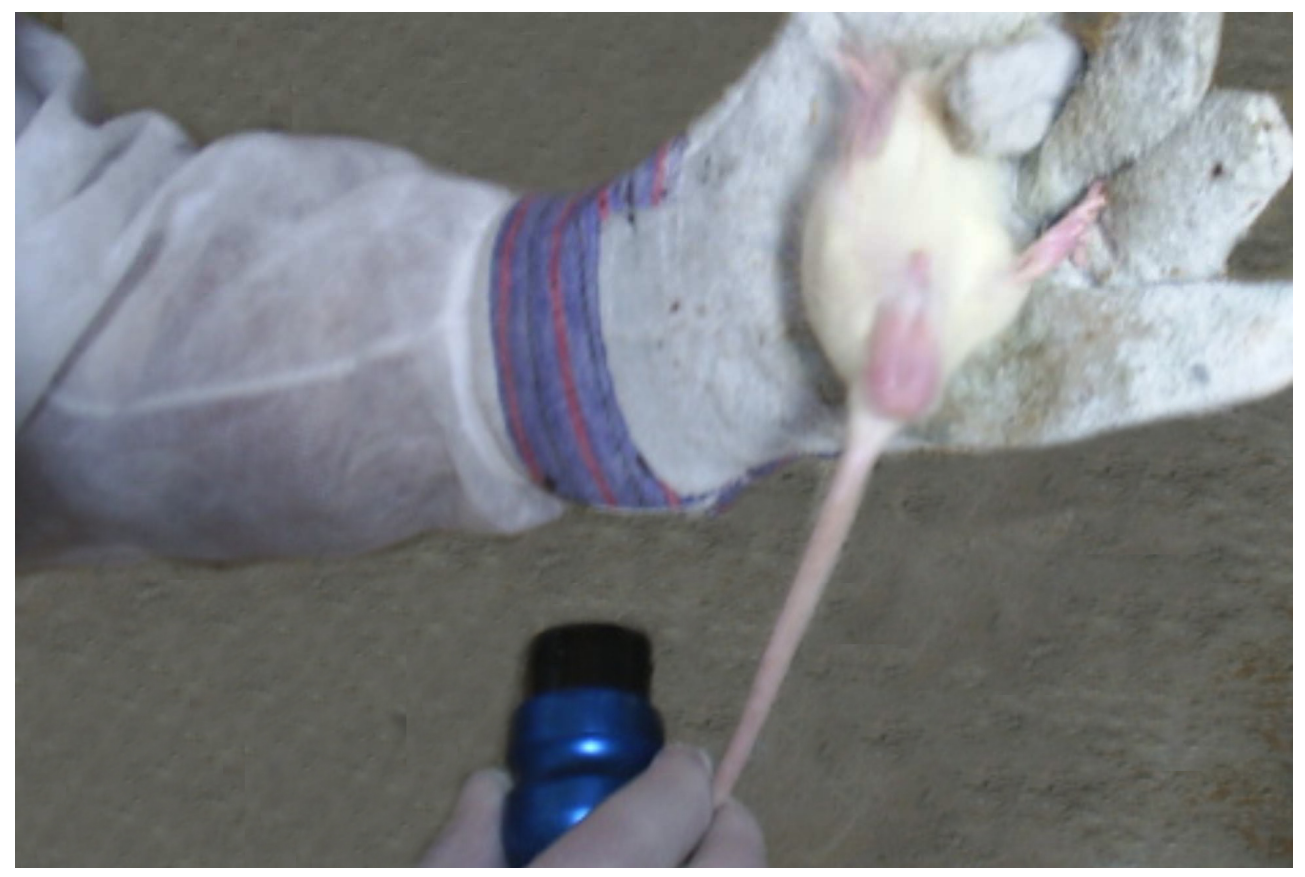

Figura 5: A fotografia mostra o transdutor ultra-sônico a ser acoplado à bolsa escrotal para estimulação dos testículos.

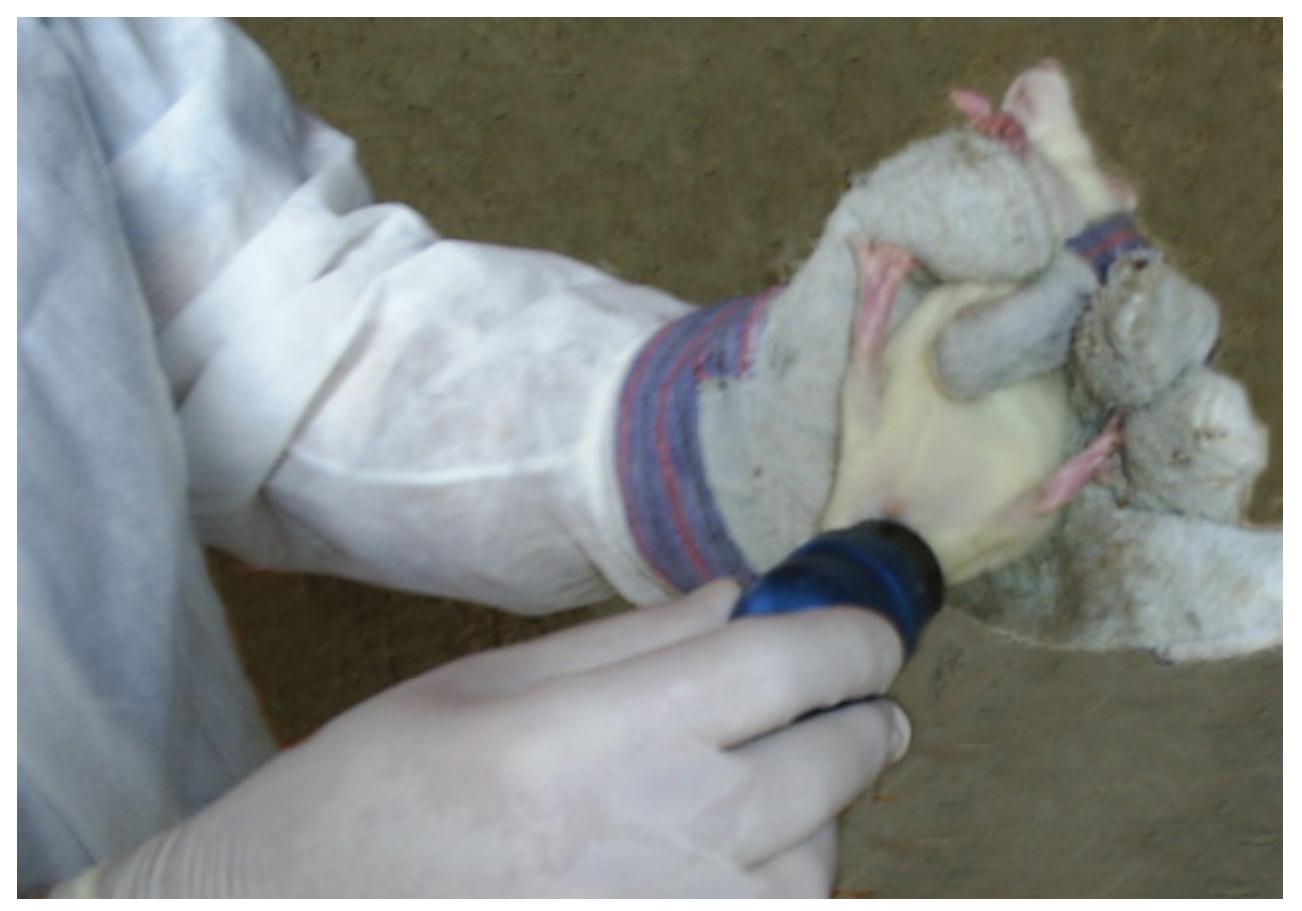

Figura 6: A fotografia mostra o transdutor acoplado sobre a bolsa escrotal para estimular os testículos dos animais na posição ventral. 


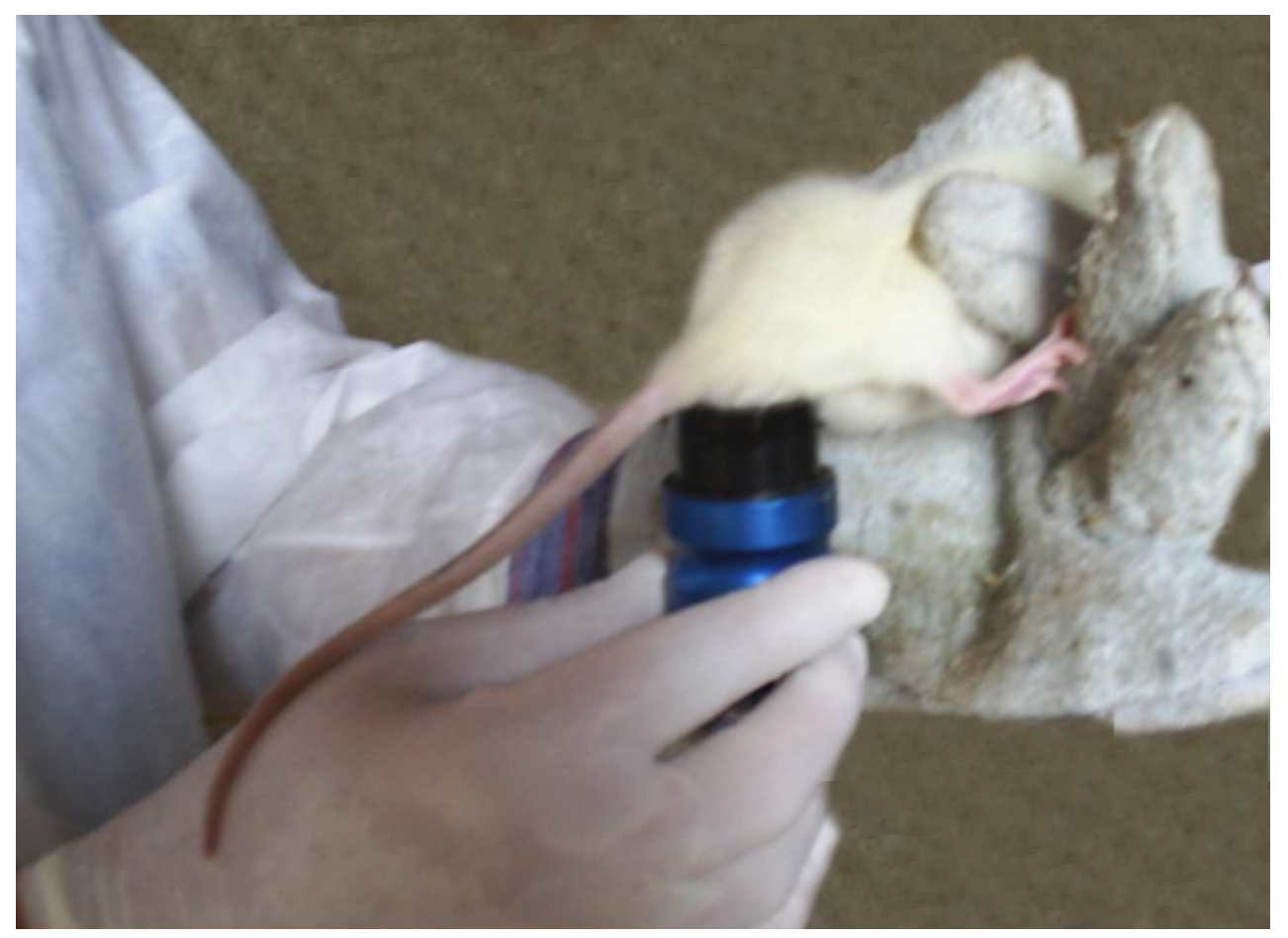

Figura 7: A fotografia mostra o transdutor acoplado sob a bolsa escrotal para estimular os testículos dos animais na posição dorsal. 


\section{4 - A Colchicina como Agente Mitostático}

A Colchicina é um agente mitostático utilizado experimentalmente para estudar a multiplicação celular. Em virtude de se ligar a tubulina, a colchicina interfere com a função dos fusos mitóticos e causa a despolimerização e a não formação dos microtúbulos fibrilares bloqueando a seqüência da divisão celular em metáfase.

A colchicina pode interromper a divisão das células animais e vegetais in vitro $e$ in vivo. A mitose é interrompida em metáfase, devido à impossibilidade de formar fusos.

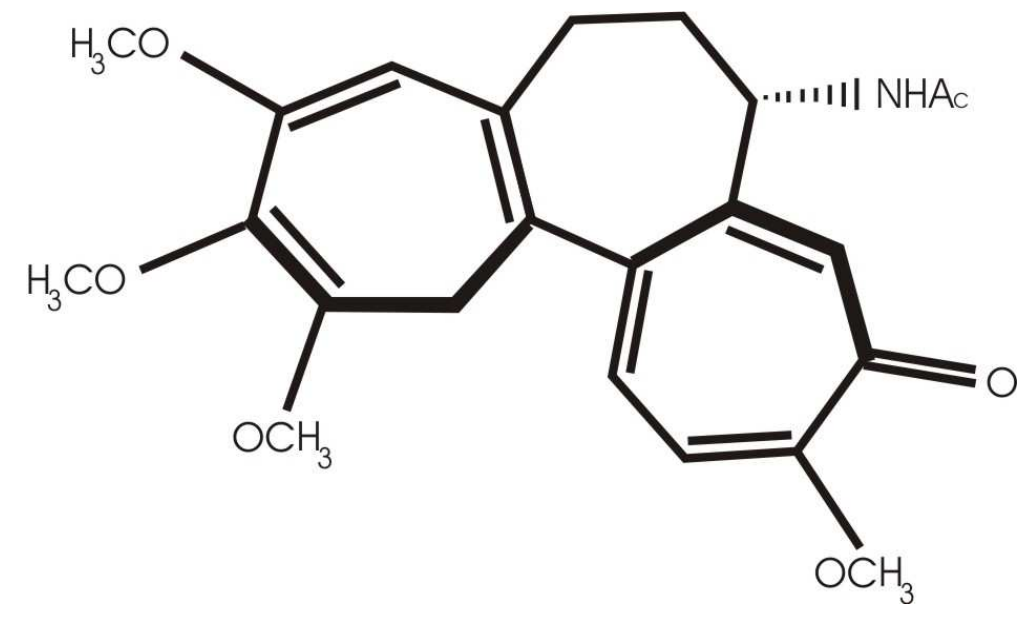

Figura 8 - Estrutura Química da Colchicina.

O objetivo do uso da colchicina é de avaliar a quantidade de células com seu ciclo mitótico bloqueado em metáfase e para permitir comparações entre o número de células quando submetidos ao estimulo do Ultra-Som Pulsado de Baixa Intensidade.

\subsection{1 - Uso da Colchicina}

Seis horas antes do sacrifício, todos os animais receberam Colchicina via intramuscular, na proporção de 0,10 miligramas para cada 100 gramas de massa corporal, tempo necessário para interromper a divisão das células bloqueando o seu ciclo mitótico em metáfase. 


\section{5 - Coleta do material}

Os grupos experimentais I e II de ratos pré-púberes foram sacrificados 24 horas após a última sonicação.

Os grupos experimentais III e IV de ratos sexualmente maduros foram sacrificados trinta dias após a última sonicação, a fim de poder avaliar a progressão do ciclo espermatogenético.

Os animais foram sacrificados, sem sofrimento, com a administração excessiva de anestésico, Rompum ${ }^{\circledR}$ (Cloridrato de xilazina) e Ketalar® (Cloridrato de Cetamina), procedendo-se a seguir a coleta, dos testículos, epidídimo (cabeça e cauda), próstata e vesículas seminais, identificados, colocados em frascos separados com solução fixadora (formaldeido neutro 10\%), por um período de 4 horas, e a seguir foram ligeiramente secos em papel de filtro, pesados em balança de precisão e recortados, e reconduzidos ao fixador até completar uma fixação adequada (cerca de 48 horas). Após processamento de rotina para inclusão em parafina, cortes de $7 \mu \mathrm{m}$ foram obtidos e corados com Hemalumem e Eosina (HE). 
A figura 9 mostra os testículos de ratos pré-púberes e ratos adultos estimulados e não estimulados com Ultra-som Pulsado de Baixa Intensidade.

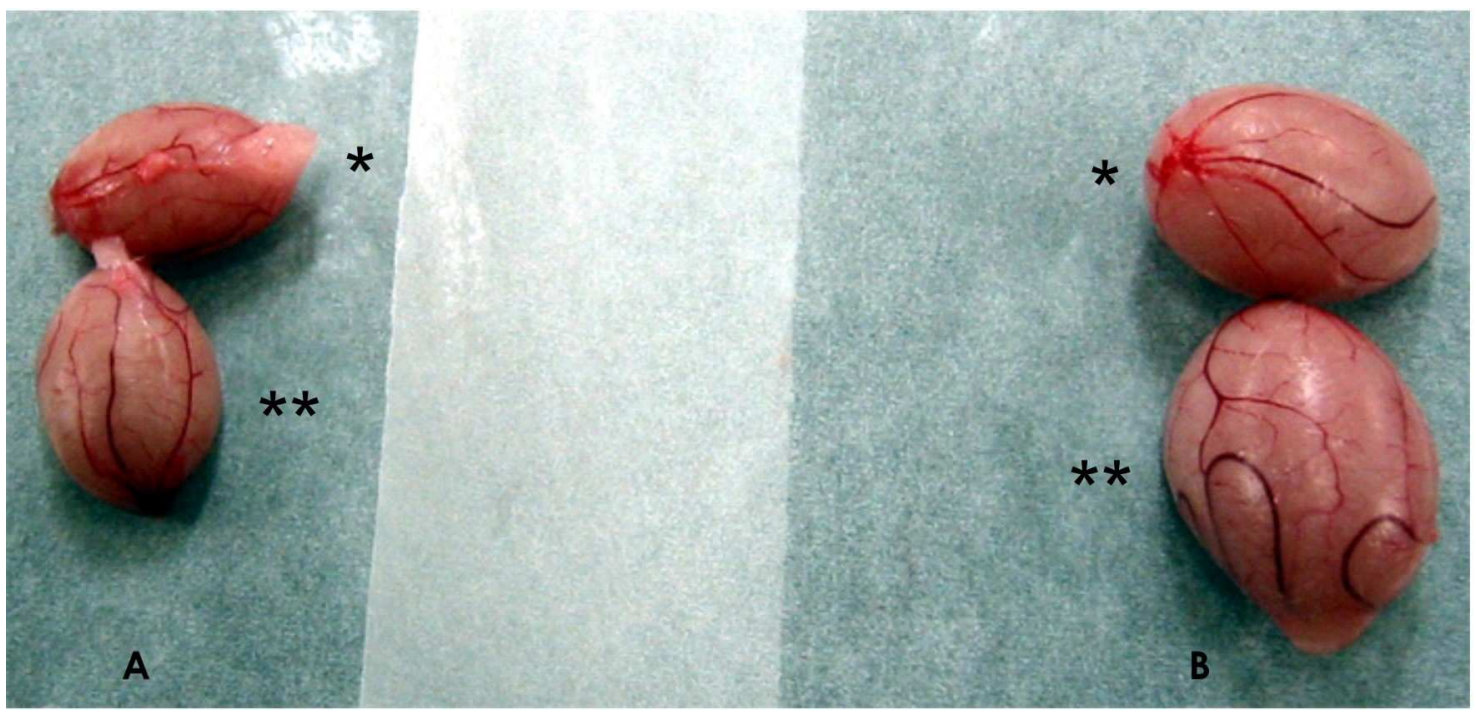

Figura 9: Fotografias de testículos de ratos pré-púberes e adultos estimulados ou não (A.ca. de 3x).

Fotografia A: testículo de rato pré-púbere, o órgão marcado com um asteristico é de animal controle, dois asteristicos correspondem a testículo estimulado.

Fotografia B: testículo de ratos adultos, o órgão marcado com um asteristico é de animal controle, dois asteristicos correspondem a testículo estimulado. 


\section{6 - Análise Morfométrica e Estatística}

A análise morfométrica foi executada em fotografia de cortes histológicos do testículo de animais dos dois grupos experimentais estimulados ou não. As fotografias foram obtidas sob microscopia de luz e aumento de 40x.

As áreas dos túbulos seminíferos foram estimadas morfometricamente em testículos de animais de todos os grupos experimentais, estimulados ou não.

Estimou-se também a freqüência dos estádios VII, VIII e XIV do ciclo espermatogenético de todos os animais estimulados ou não.

Para a morfometria das áreas foram medidas apenas aquelas cujos túbulos seminíferos apareciam nas preparações histológicas cortados transversalmente, de ratos adultos e pré-púberes estimulados ou não. As avaliações das áreas foram executadas sobre 62 (sessenta e duas) fotomicrografias de cortes histológicos.

As fotomicrografias foram analisadas com auxilio de um programa de computador específico para análise de imagens chamada Image Tool.

Mediram-se áreas de cerca de 144 (cento e quarenta e quatro) túbulos de ratos adultos estimulados e não estimulados, e cerca de 116 (cento e dezesseis) áreas de túbulos de ratos pré-púberes estimulados e não estimulados.

O segundo parâmetro analisado foi o da freqüência dos estádios VII, VIII e XIV do ciclo espermatogênico nas mesmas fotomicrografias dos cortes histológicos dos testículos de todos os animais.

Foram avaliados também em balança de precisão os pesos dos testículos dos animais componentes dos grupos experimentais III e IV (sexualmente maduros), ou seja, apenas dos animais adultos. 
A seqüência de micrografias da página 68 a 82 tem por finalidade ilustrar a caracterização dos estadios do ciclo espermatogenético, sobre os quais foram feitas as morfométrias e a freqüência dos mesmos, no ciclo.

Procura-se assim, demonstrar a exeqüibilidade do que fora proposto para a avaliação dos efeitos do Ultra Som Pulsado de Baixa Intensidade. 

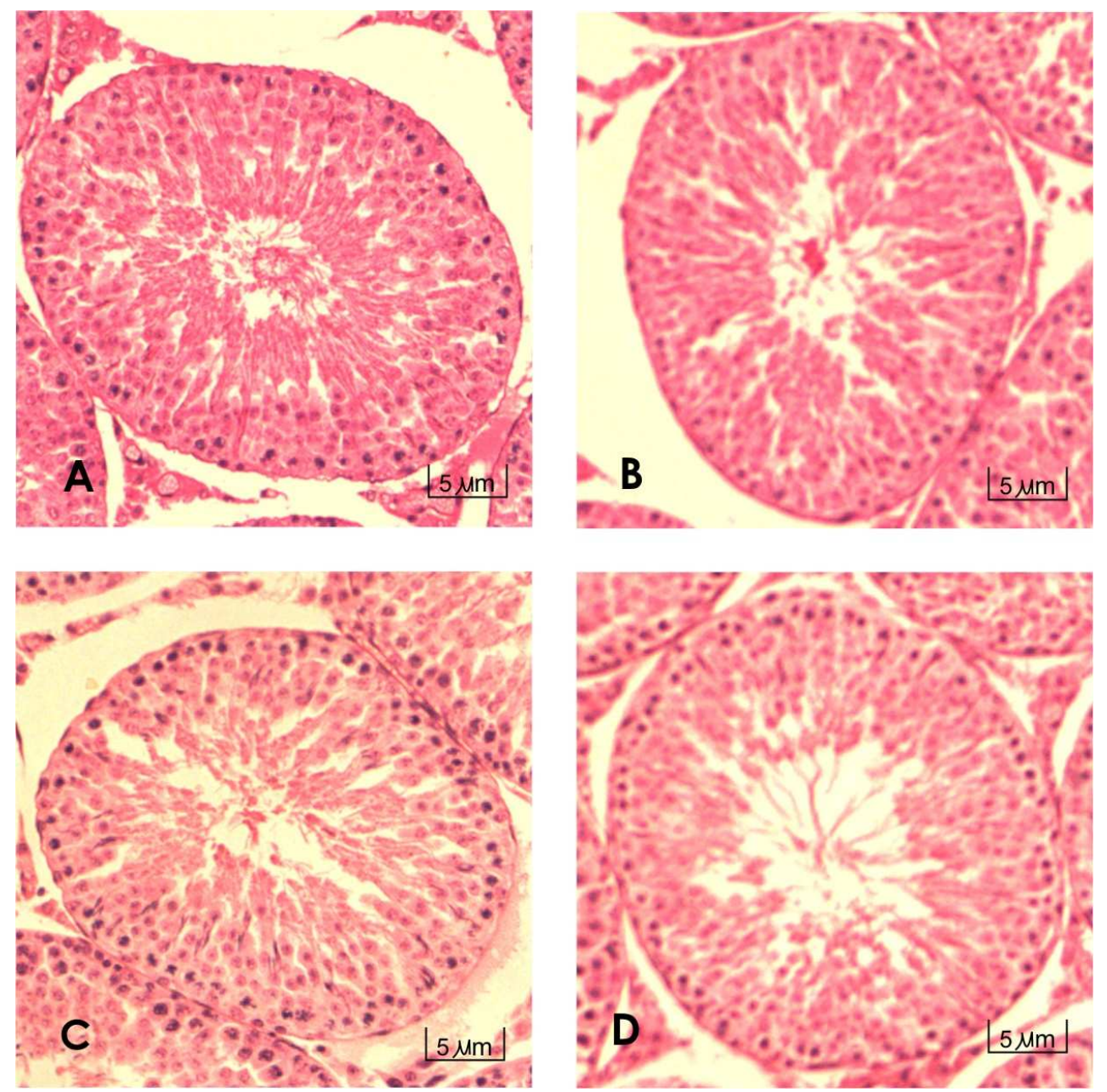

Figura10: Fotomicrografias de cortes transversais de túbulos seminíferos de animais pré-púberes (A । $B$ ) e adultos ( $C$ e $D)$, onde $(A$ e $C$ ) controle e $(B$ e $D)$ estimulado caracterizando o estadio VII do cic espermatogenético.

Fotomicrografia de cortes transversais de túbulos seminíferos de animais prépúberes e adultos estimulados ou não. (A): Espermatozóides jovens no terço superior do epitélio do túbulo seminífero, caracterizando o estádio VII do ciclo espermatogenético de ratos pré-púberes controle. (B): Espermatozóides jovens no terço superior do epitélio do túbulo seminífero, caracterizando o mesmo estadio de ratos pré-púberes estimulado. (C): Espermatozóides jovens no terço superior do epitélio do túbulo seminífero, caracterizando o estadio VII de ratos adulto controle. (D): Espermatozóides jovens no terço superior do epitélio do túbulo seminífero, caracterizando o mesmo estadio de rato adulto estimulado. 

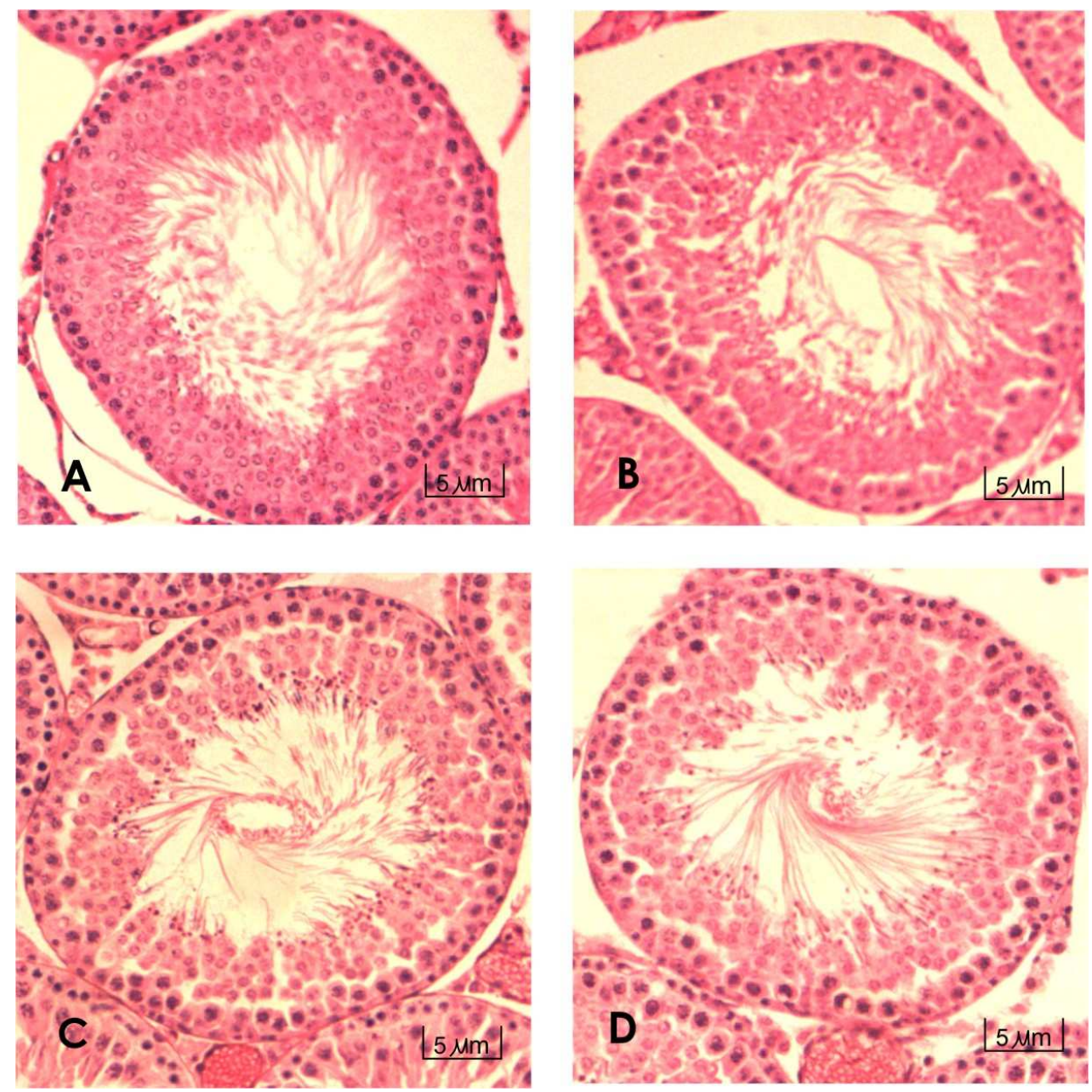

Figura 11: Fotomicrografia de cortes transversais de túbulos seminíferos de animais pré-púberes $(\boldsymbol{A}$ e $B$ ) e adultos $(C$ e $D)$ onde $(A$ e $C)$ controle e $(B$ e $D)$ estimulado caracterizando o estadio VIII do ciclo espermatogenético.

Fotomicrografia de cortes transversais de túbulos seminíferos de animais prépúberes e adultos estimulados ou não. (A): Os espermatozóides maduros formam uma camada contínua em vias de expulsão na luz do túbulo seminífero e as caudas apresentam-se formando vórtices, características do estadio VIII do ciclo espermatogenético dos ratos pré-púbere controle. (B): caracterizando o estadio VIII de rato pré-púbere estimulado. (C): caracterizando o mesmo estadio VIII de rato adulto controle. (D): caracterizando o mesmo estadio de rato adulto estimulado. 

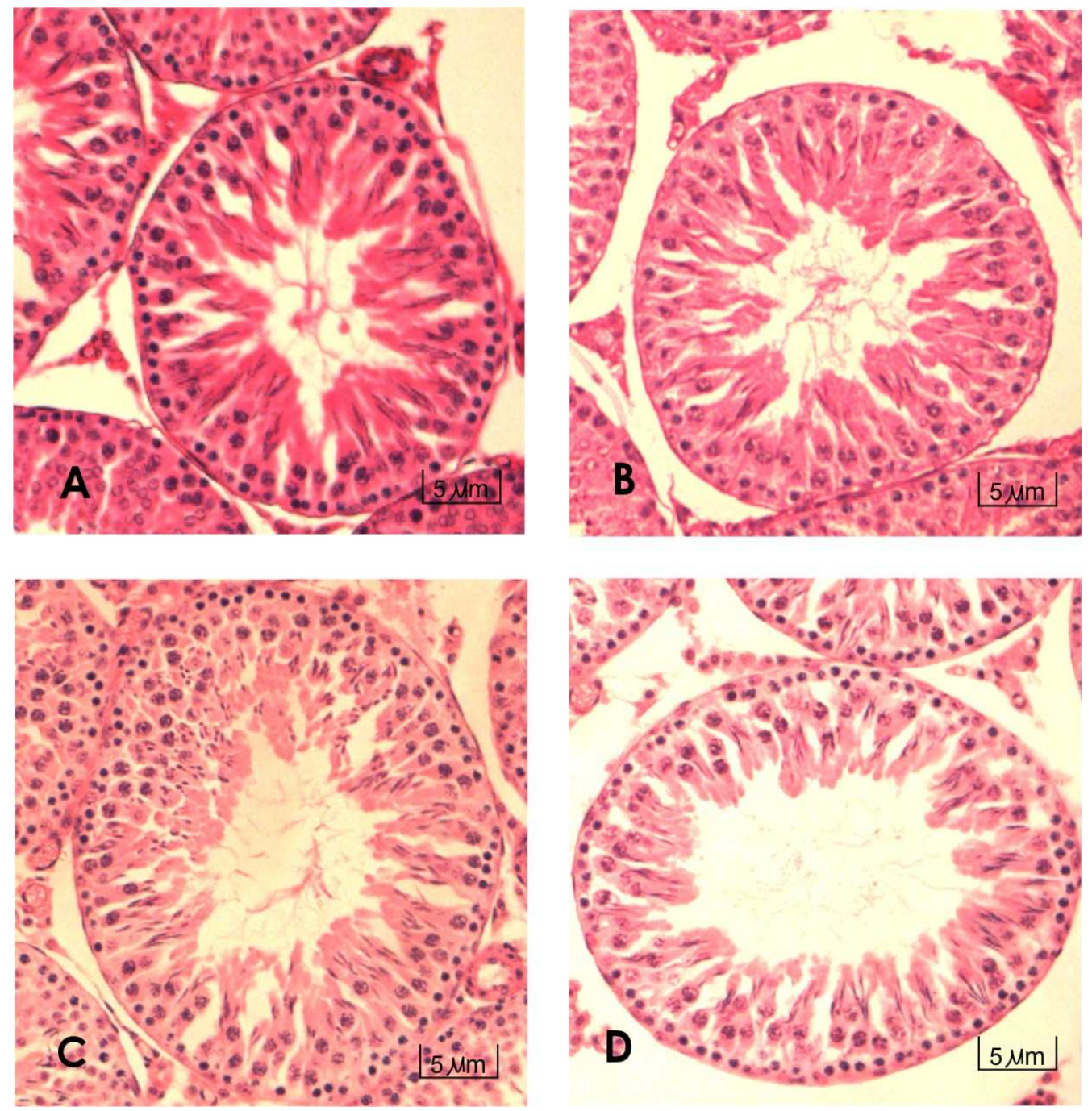

Figura 12: Fotomicrografia de cortes transversais de túbulos seminíferos de animais pré-púberes (A e $B$ ) e adultos ( $C$ e $D$ ) onde $(A$ e $C$ ) controle e ( $B$ e $D$ ) estimulado, caracterizando o estadio XIV do ciclo espermatogenético.

Fotomicrografias de cortes transversais de túbulos seminíferos de animais pré-púberes e adultos estimulados ou não. (A): A presença de mitoses reducionais, caracteriza o estádio XIV do ciclo espermatogenético de rato prépúbere controle. (B): A presença de mitoses reducionais, caracteriza o mesmo estadio de rato pré-púbere estimulado. (C): Caracteriza mesmo estadio de rato adulto controle. (D): Caracteriza o mesmo estadio de rato adulto estimulado. 
A seqüência de figuras às páginas 71 a 82 apresenta cortes histológicos de testículos de ratos pré-púberes e adultos estimulados e não estimulados ilustra 0 conjunto de túbulos seminíferos apresentando diferentes estadios do ciclo espermatogenético.

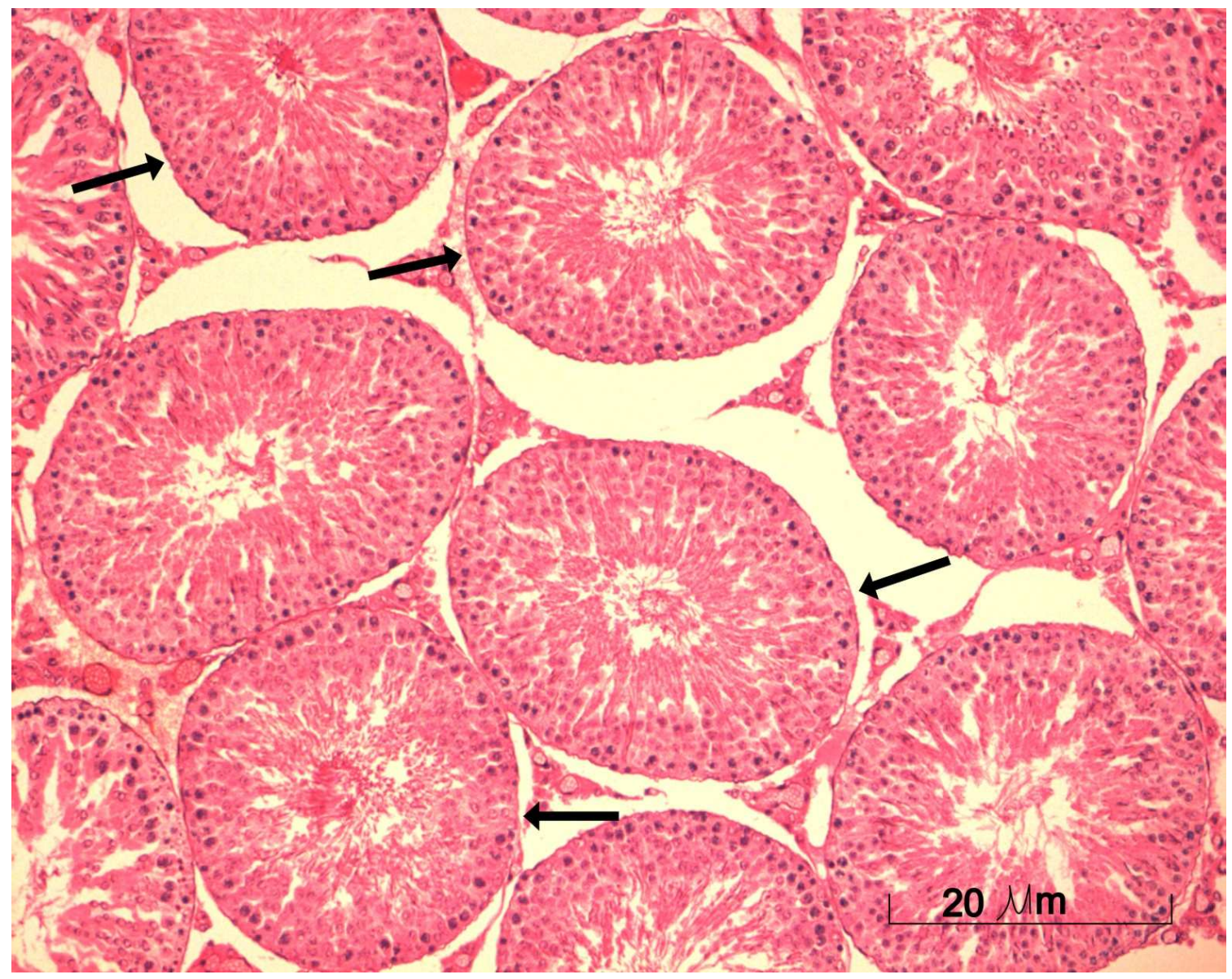

Figura 13: Fotomicrografia de túbulos seminíferos em cortes transversais de testículo de rato prépúbere controle. As setas indicam os túbulos que representam o estadio VII do ciclo espermatogenético.

Figura 13: mostra cortes de túbulos seminíferos no estadio VII de ratos prépúberes controle, portanto expostos a uma estimulação fictícia, na qual pode-se notar a presença de espermatozóides jovens no terço superior do túbulo seminífero, formando uma camada contínua. 


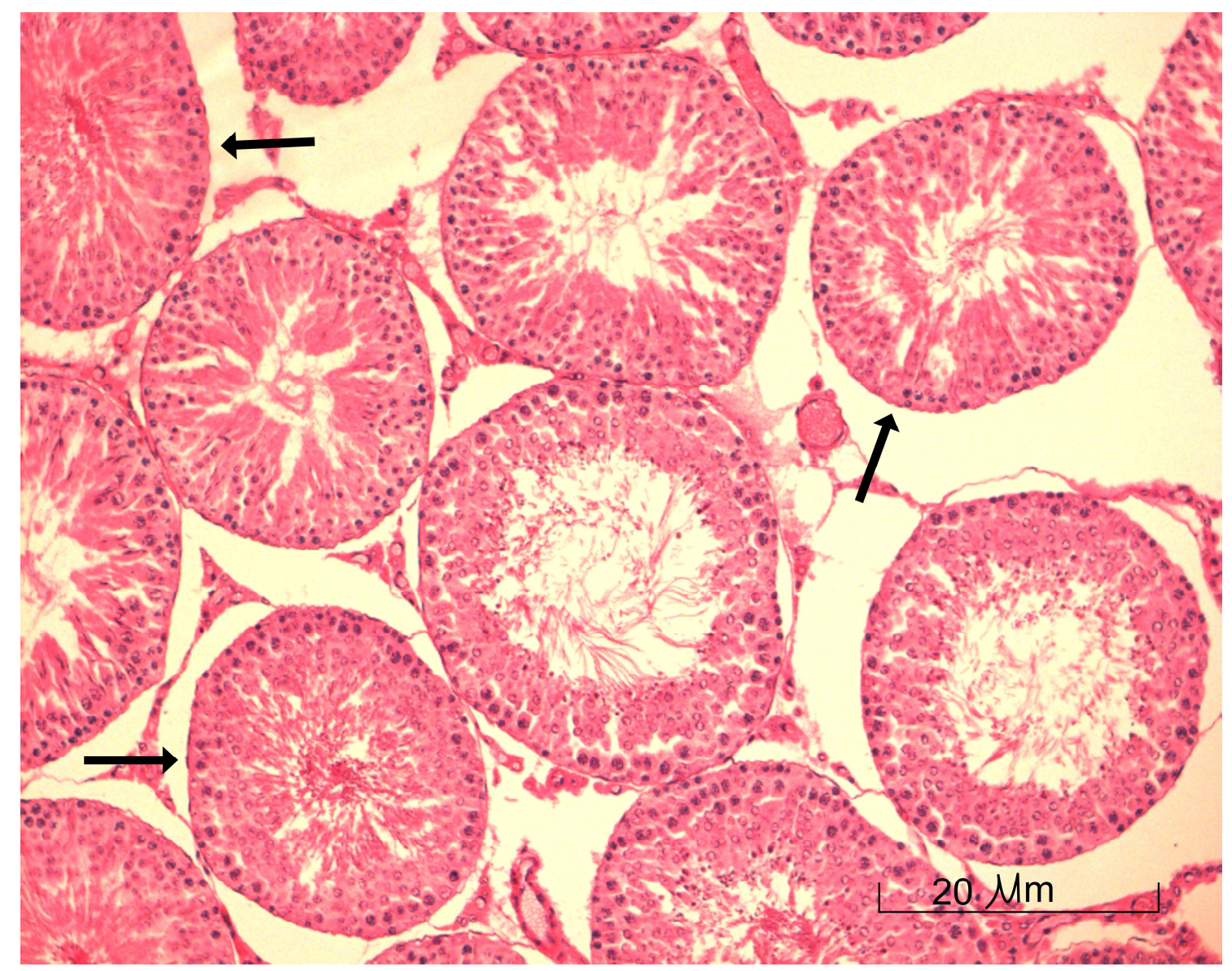

Figura 14: Fotomicrografia de túbulos seminíferos em cortes transversais de testículo de rato prépúbere estimulado. As setas indicam os túbulos que representam o estadio VII do ciclo espermatogenético.

Figura 14: Cortes de túbulos seminíferos no estadio VII de rato pré-púbere estimulado. 


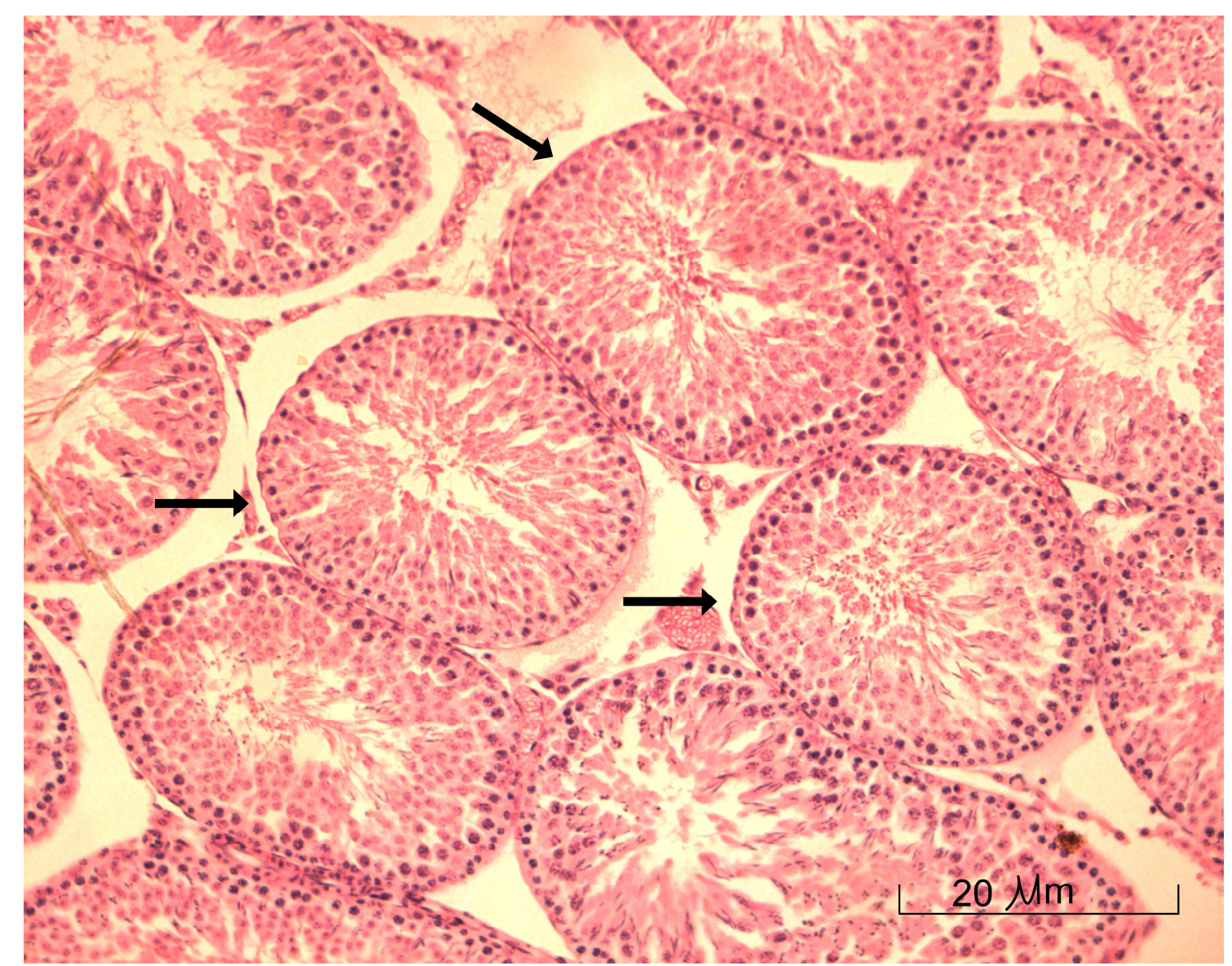

Figura 15: Fotomicrografia de túbulos seminíferos em cortes transversais de testículo de rato adulto controle. As setas indicam os túbulos que representam o estadio VII do ciclo espermatogenético.

Figura 15: Cortes de túbulos seminíferos no estadio VII de rato adulto controle, portanto exposto a uma estimulação fictícia. 


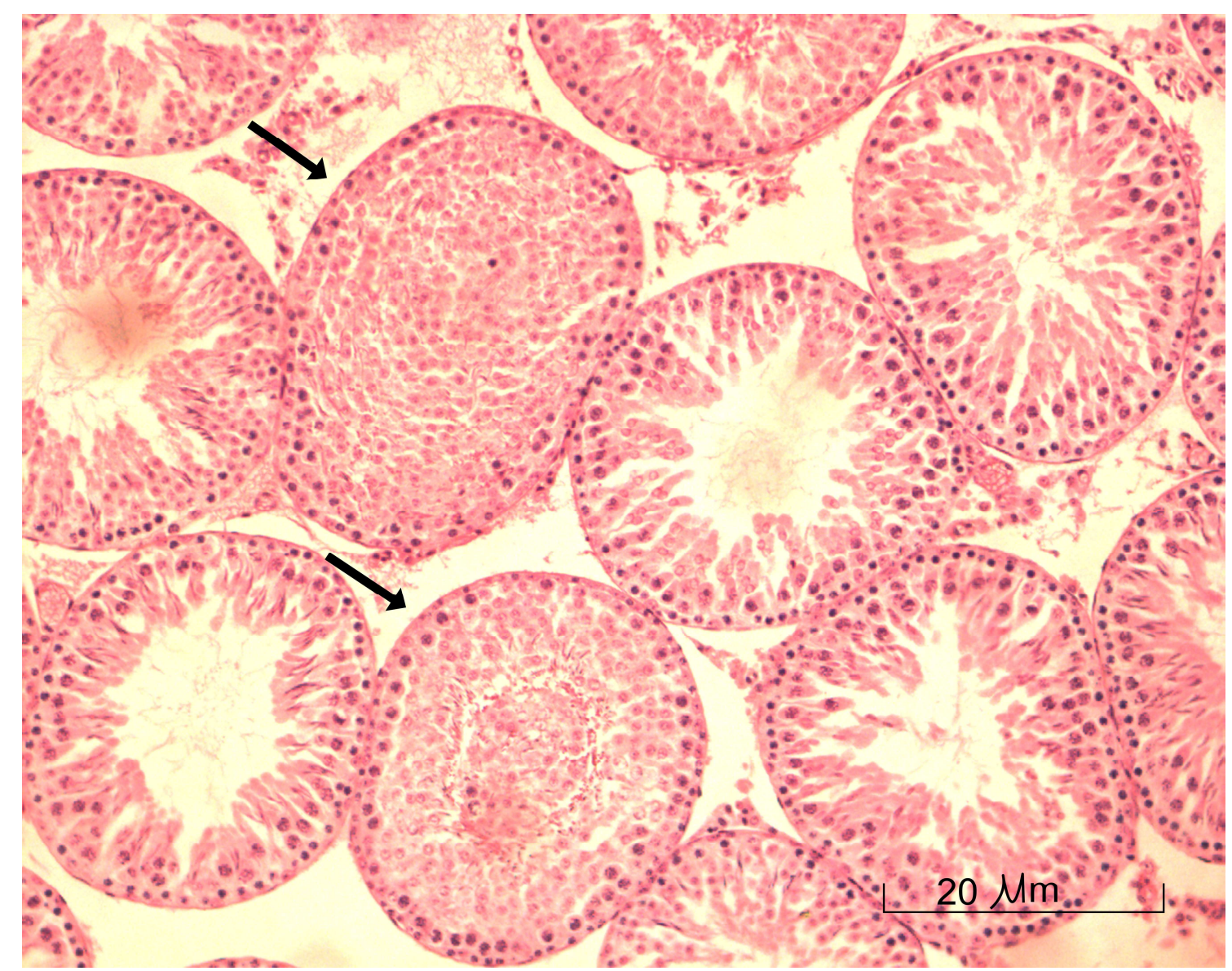

Figura 16: Fotomicrografia de túbulos seminíferos em cortes transversais de testículo de rato adulto estimulado. As setas indicam os túbulos que representam o estadio VII do ciclo espermatogenético

Figura 16: Cortes apresentando um predomínio do estadio VII nos túbulos seminíferos de testículo de rato adulto estimulado. 


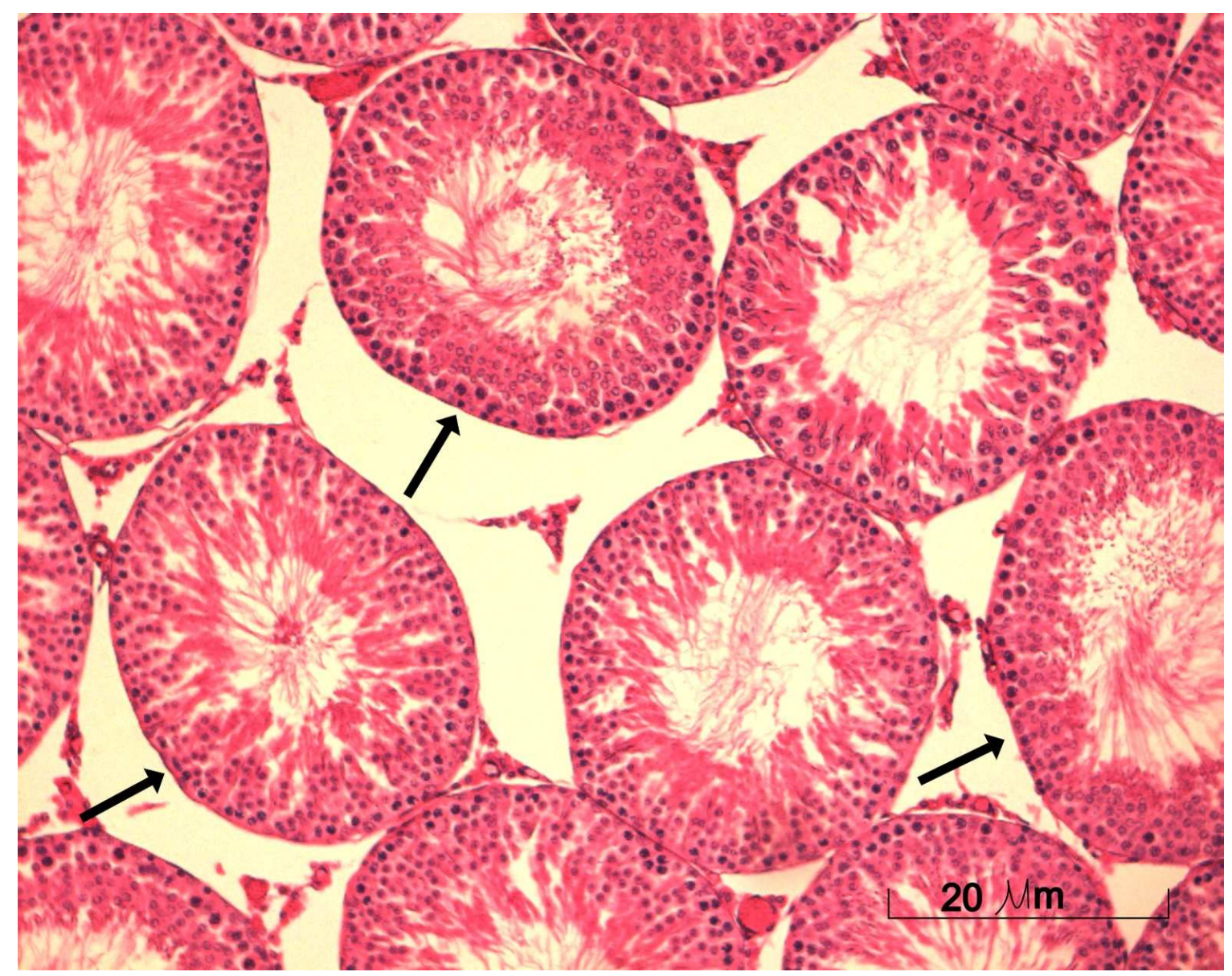

Figura 17: Fotomicrografia de túbulos seminíferos em cortes transversais de testículo de rato pré-púbere controle. As setas indicam os túbulos que representam o estadio VIII do ciclo espermatogenético.

Figura 17: Mostra um predomínio do estadio VIII nos túbulos seminíferos de testículo de rato pré-púbere controle. 


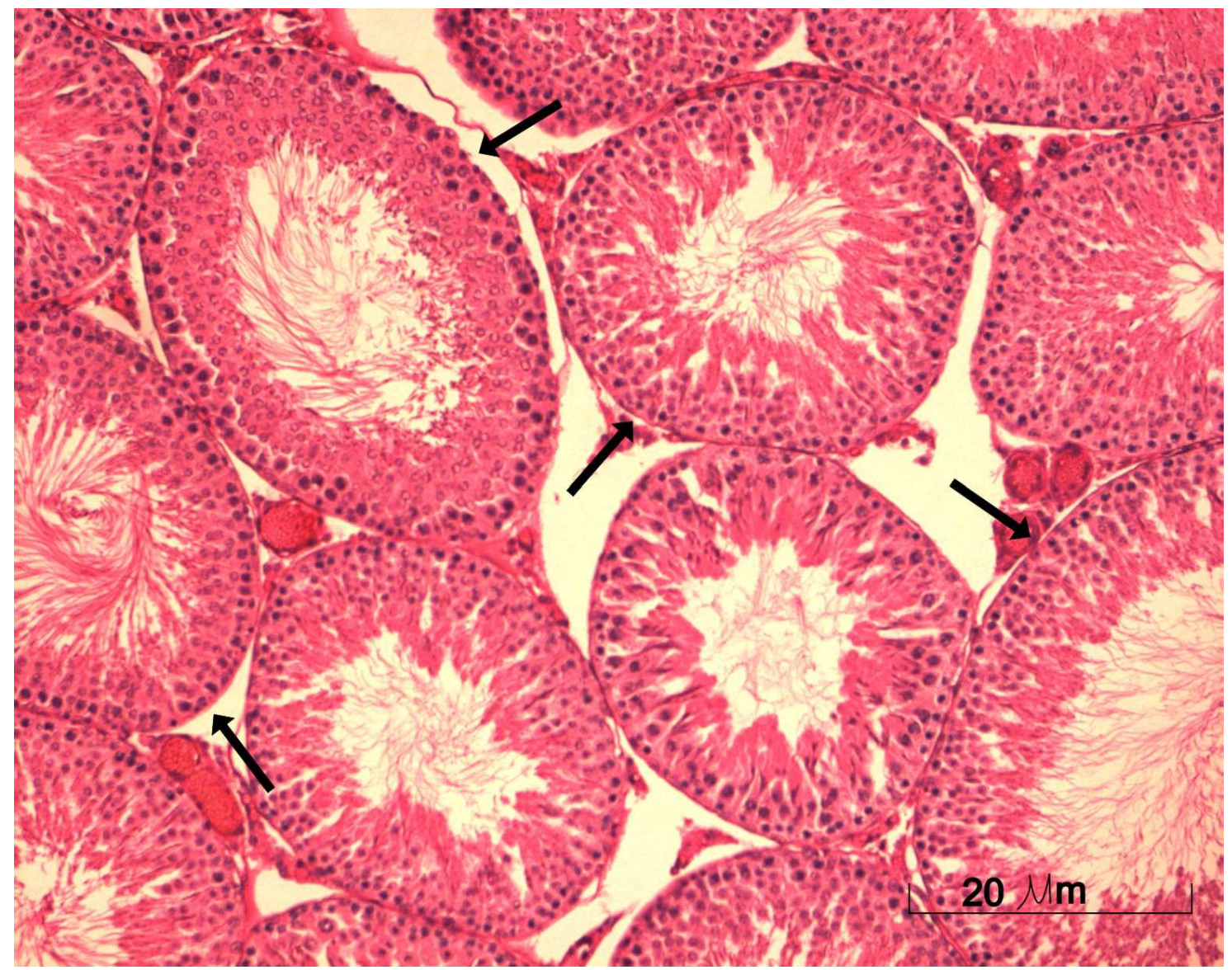

Figura 18: Fotomicrografia de túbulos seminíferos em cortes transversais de testículo de rato prépúbere estimulado. As setas indicam os túbulos que representam o estadio VIII do ciclo espermatogenético

Figura 18: Embora as fotomicrografias tivessem sido obtidas de maneira aleatória pode-se notar predomínio do estadio VIII nos túbulos seminíferos de testículo de rato pré-púbere estimulado. 


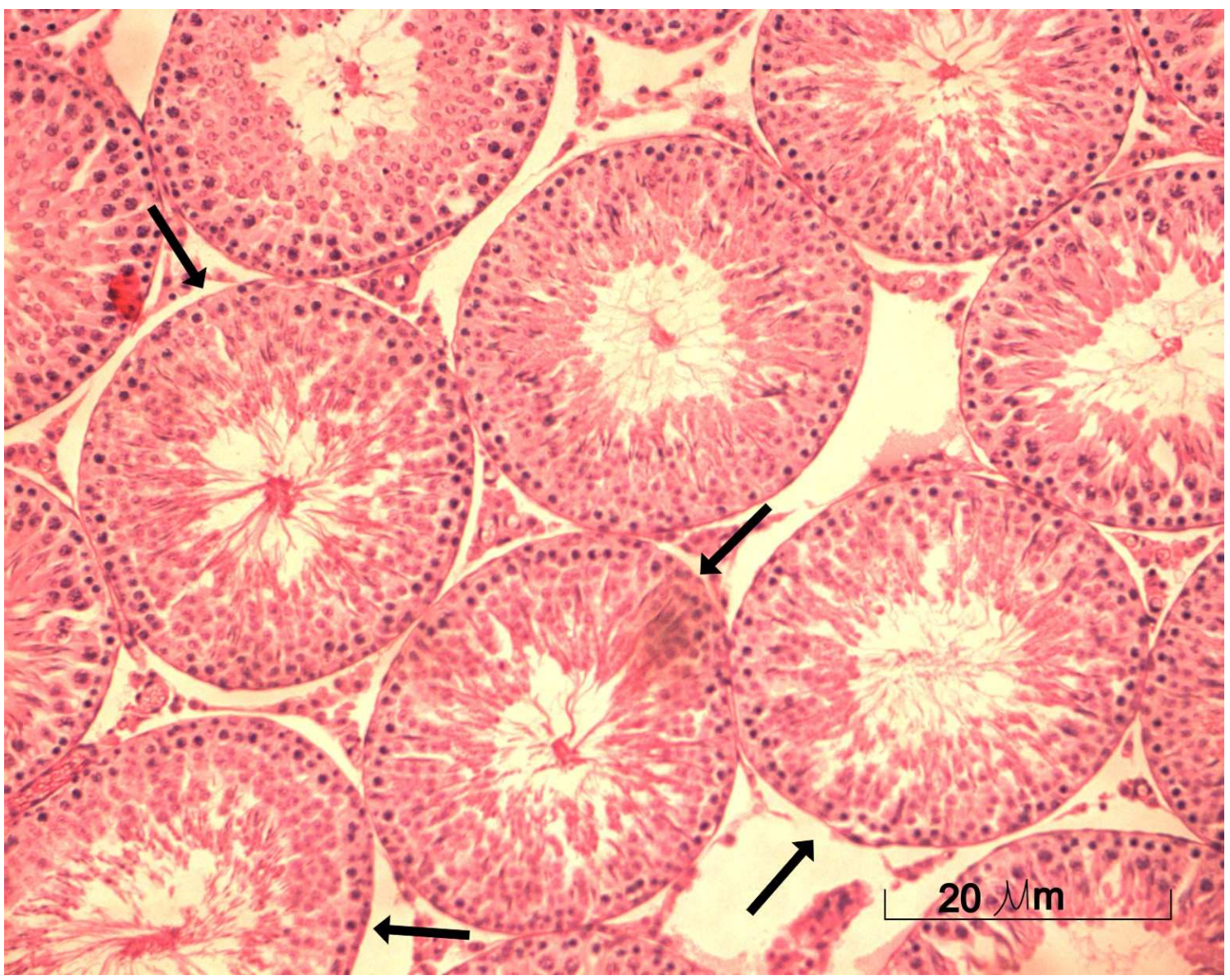

Figura 19: Fotomicrografia de túbulos seminíferos em cortes transversais de testículo de rato adulto controle. As setas indicam os túbulos que representam o estadio VIII do ciclo espermatogenético.

Figura 19: Cortes de túbulos seminíferos no estadio VIII de testículo de rato adulto controle. 


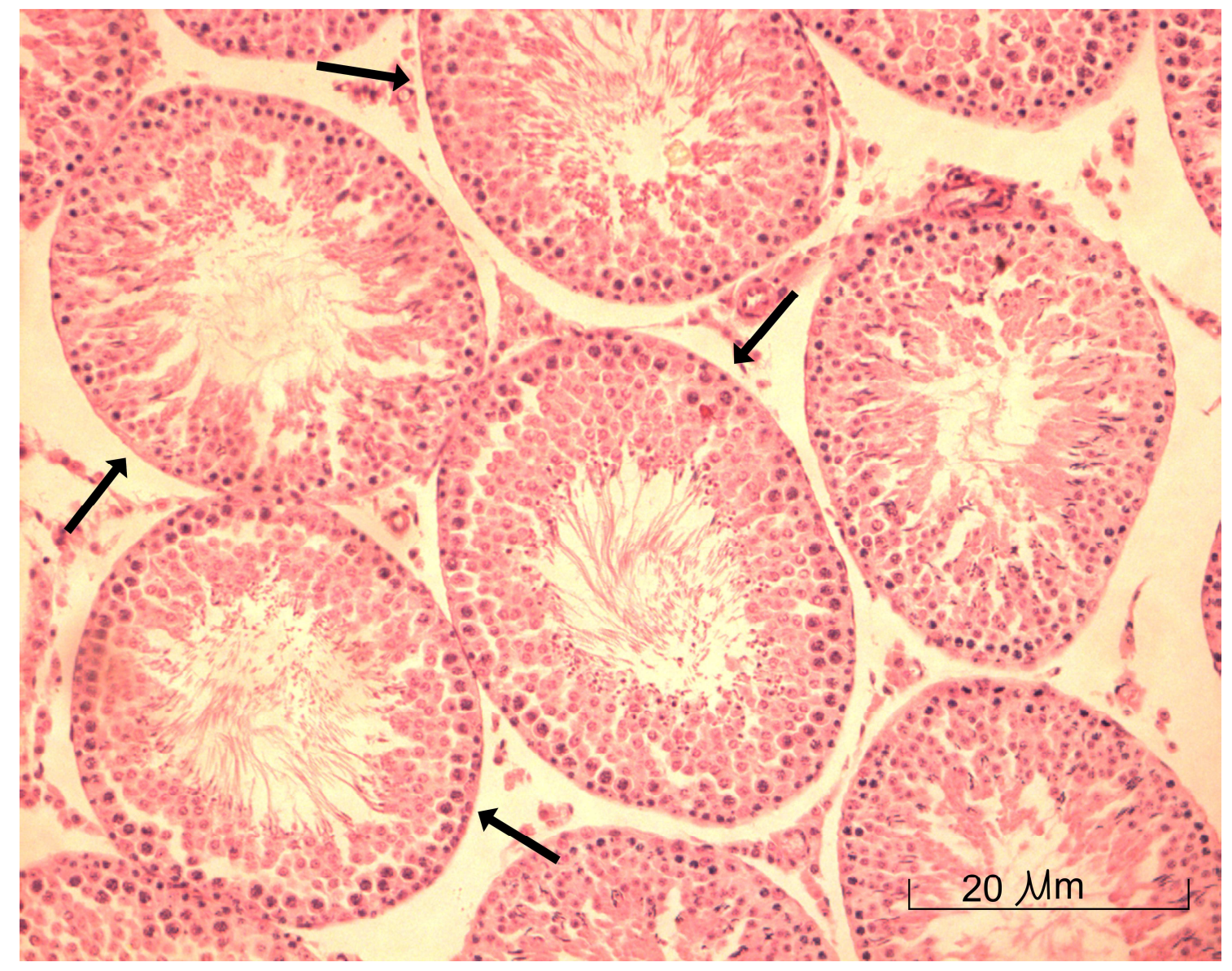

Figura 20: Fotomicrografia de túbulos seminíferos em cortes transversais de testículo de rato adulto estimulado. As setas indicam os túbulos representando o estadio VIII do ciclo espermatogenético.

Figura 20: Mostra um predomínio do estadio VIII nos túbulos seminíferos de testículo de rato adulto estimulado. 


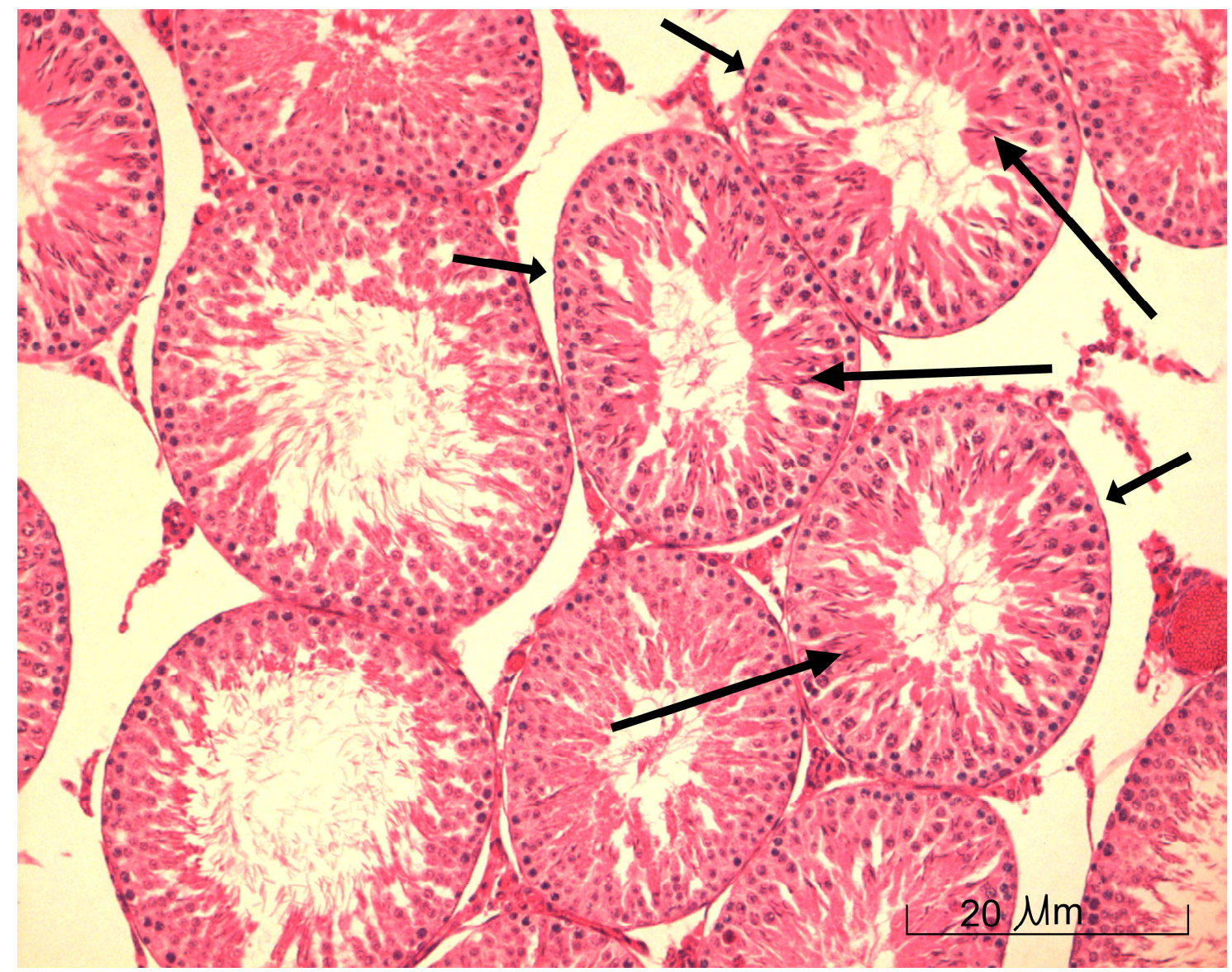

Figura 21: Fotomicrografia de túbulos seminíferos em cortes transversais de testículo de rato pré-púbere controle. As setas curtas indicam os túbulos que representam o estadio XIV do ciclo espermatogenético.

Figura 21: Mostra cortes de túbulos no estadio XIV de rato pré-púbere controle, submetido à estimulação fictícia. As setas curtas indicam os cortes dos túbulos seminíferos que representam o estádio XIV. As setas longas indicam as mitoses reducionais. 


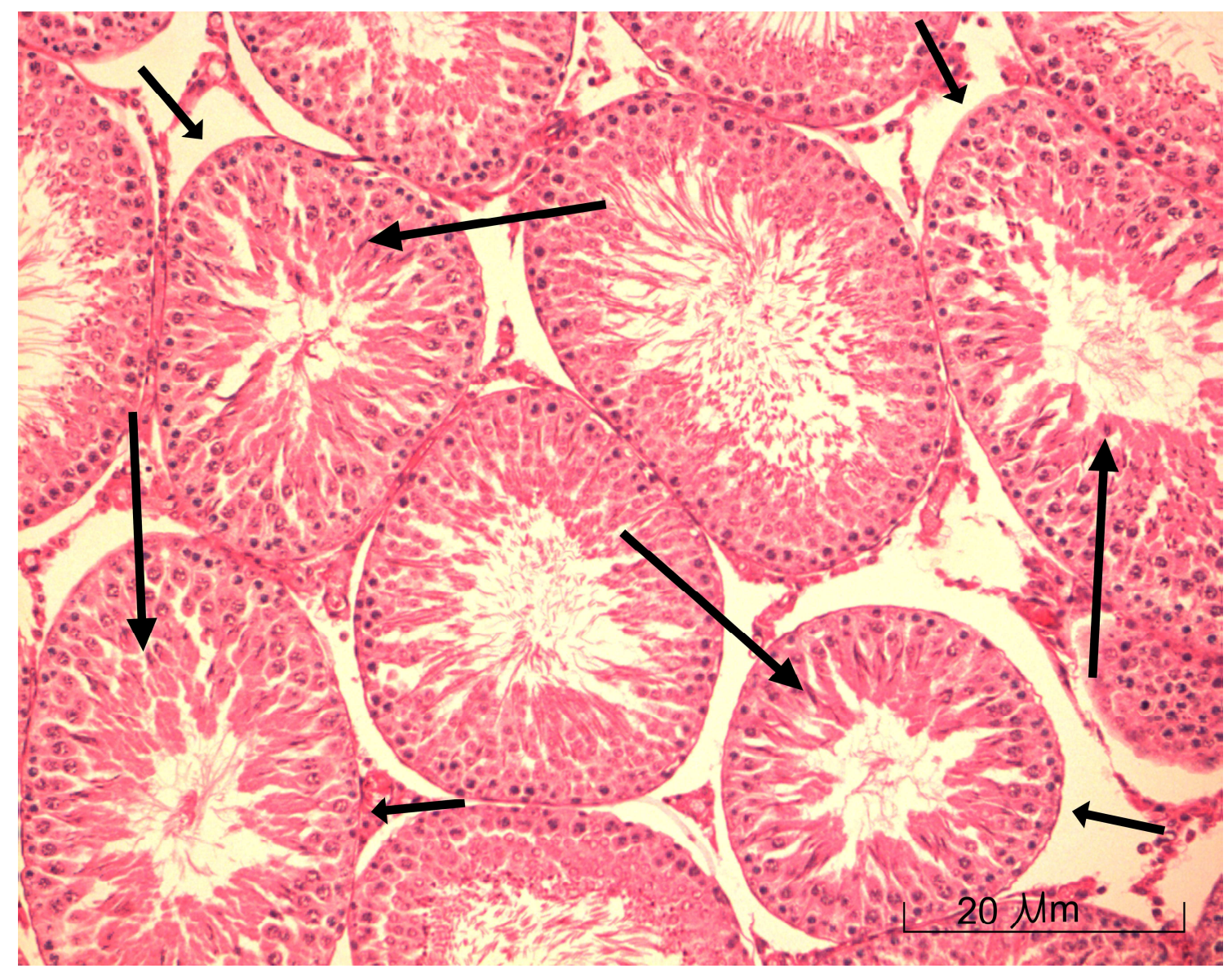

Figura 22: Fotomicrografia de túbulos seminíferos em cortes transversais de testículo de rato pré-púbere estimulado. As setas curtas indicam os túbulos que representam o estadio XIV do ciclo espermatogenético

Figura 22: Mostra cortes de túbulos no estadio XIV de rato pré-púbere estimulado. As setas curtas indicam os túbulos seminíferos que representam o estádio XIV. As setas longas indicam mitoses reducionais. 


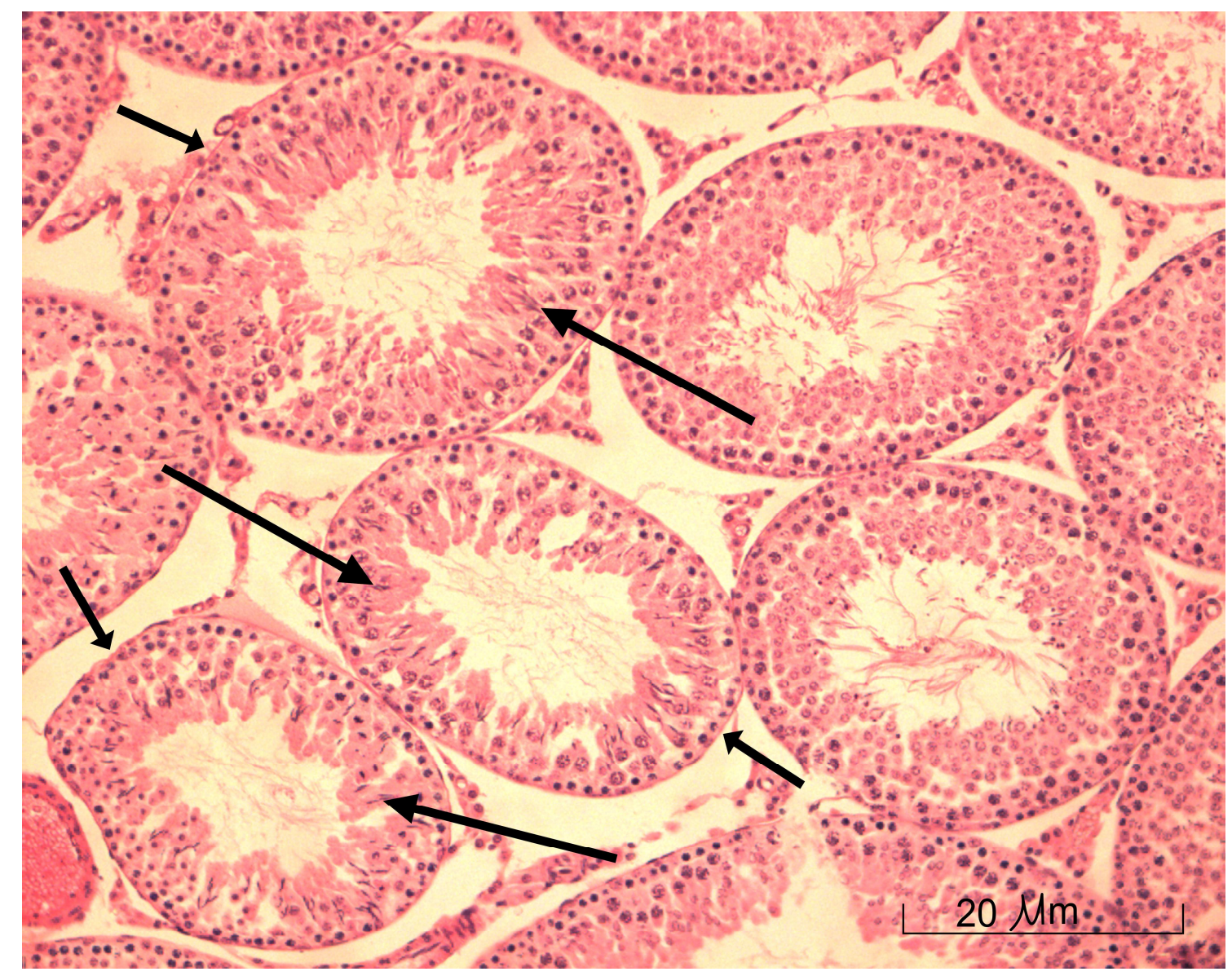

Figura 23: Fotomicrografia de túbulos seminíferos em cortes transversais de testículo de rato adulto controle. As setas curtas indicam os túbulos que representam o estadio XIV do ciclo espermatogenético

Figura 23: Mostra cortes de túbulos no estadio XIV de rato adulto controle. As setas curtas indicam os cortes dos túbulos seminíferos que representam o estádio XIV. As setas longas indicam as mitoses reducionais. 


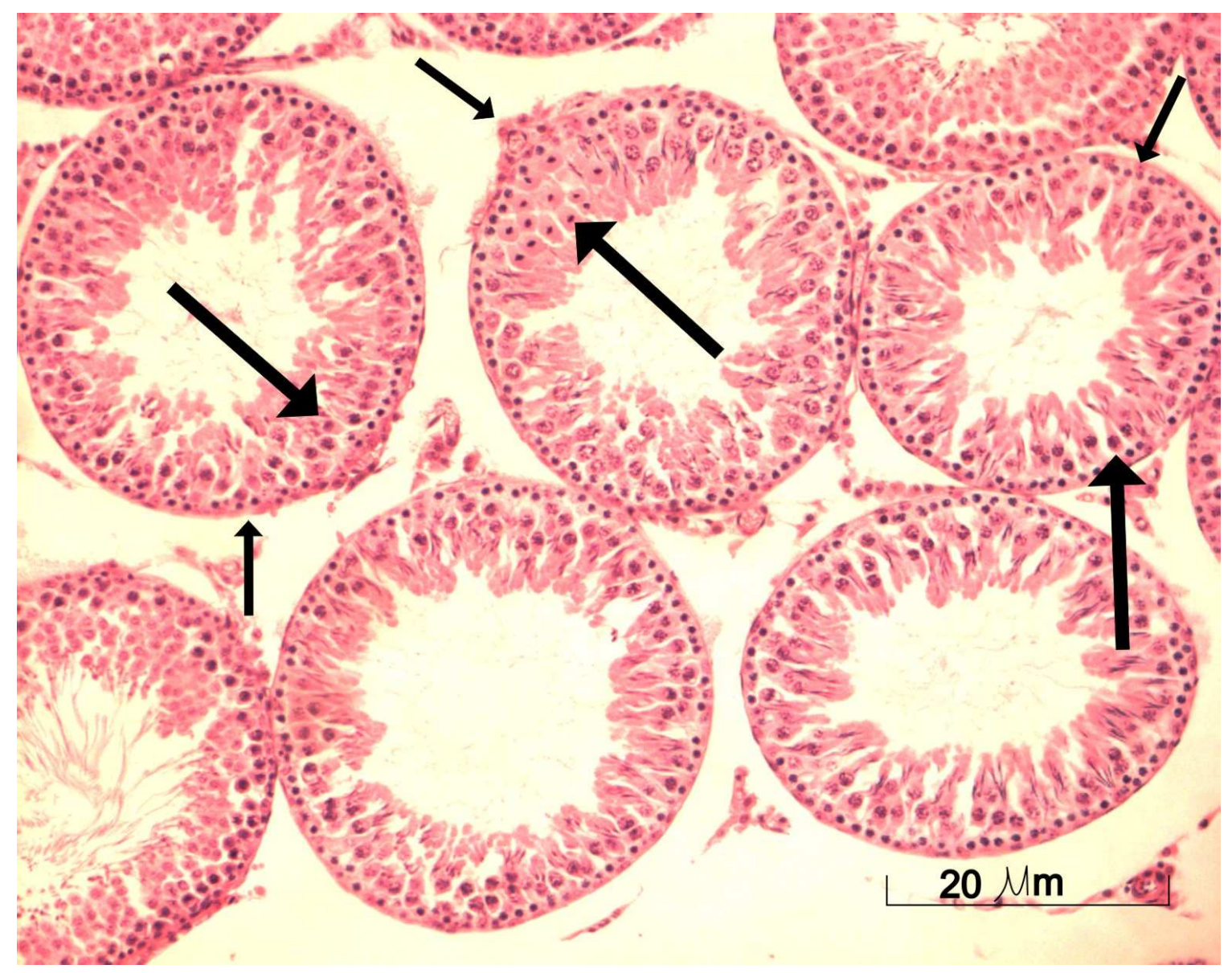

Figura 24: Fotomicrografia de túbulos seminíferos em cortes transversais de testículo de rato adultos estimulado. As setas curtas indicam os túbulos que representam o estadio XIV do ciclo espermatogenético.

Figura 24: Mostra cortes de túbulos no estadio XIV de rato adulto estimulado. As setas curtas indicam túbulos seminíferos no estadio XIV. As setas longas indicam mitoses reducionais. 
A seqüência de gráficos e os quadros resumidos às paginas 83 a 89 dos dados para os cálculos estatísticos têm por função representar os valores obtidos quanto à freqüência dos estadios; medidas das áreas tubulares e o peso dos testículos de ratos adultos.

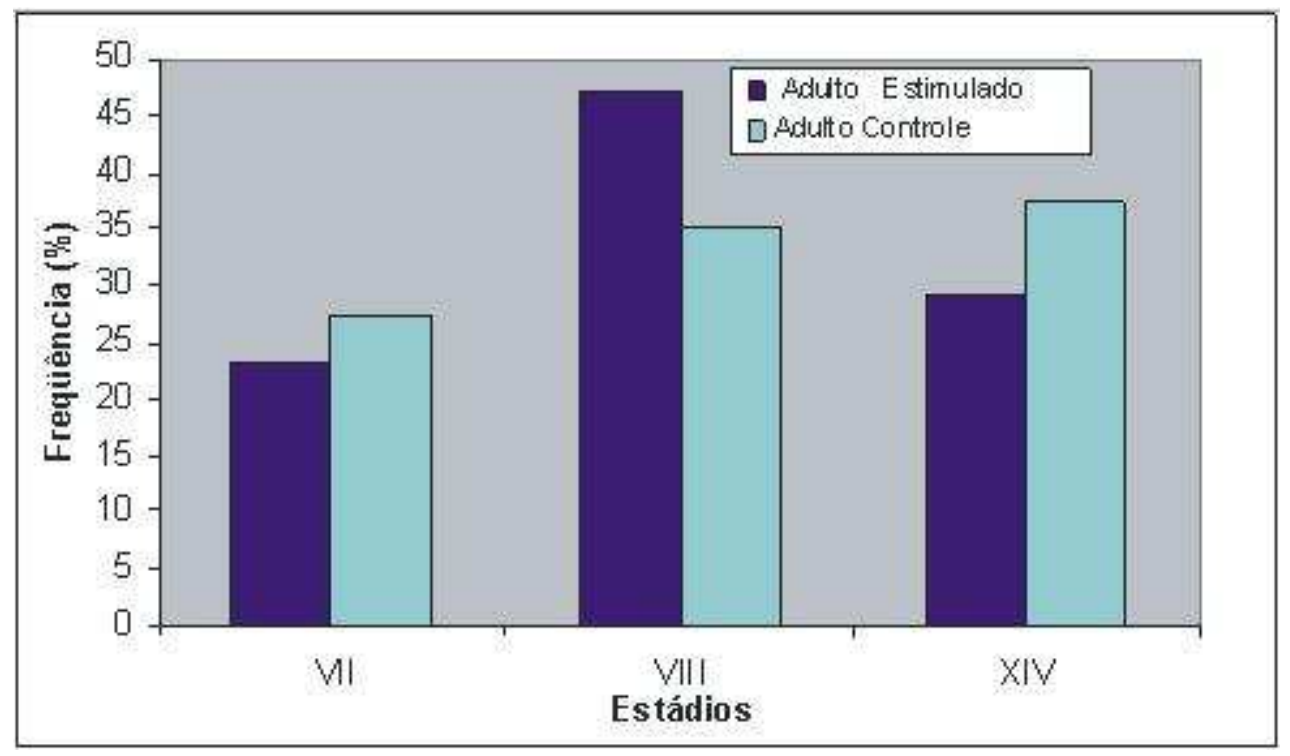

Representação gráfica da freqüência dos estadios VII, VIII e XIV em testículos de animais adultos estimulados e não estimulados com ultra-som pulsado de baixa intensidade.

O gráfico (1) representa um aumento $(10,42 \%)$ na freqüência do estádio VIII do ciclo espermatogenético de ratos adultos estimulados comparados com a freqüência dos estadios de ratos adultos controle.

Tabela 3 - ANOVA $(\alpha=0,05)$ Estadios do Ciclo Espermatogenético de Ratos Adultos Estimulados e não Estimulados.

FREQUÊNCIA DOS ESTADIOS DE RATOS ADULTOS ESTIMULADOS OU NÃO.

\begin{tabular}{cccccc}
\hline Estadios & Contagem & Soma & Média & Variância & Desvio padrão \\
\hline VII & 2 & 63 & 31,5 & 60,5 & 7,78 \\
VIII & 2 & 101 & 50,5 & 12,5 & 3,53 \\
XIV & 2 & 84 & 42 & 162,0 & 12,73
\end{tabular}

\begin{tabular}{|c|c|c|}
\hline Estadio & $\begin{array}{l}\text { Adulto } \\
\text { Estimulado }\end{array}$ & $\begin{array}{l}\text { Adulto } \\
\text { Controle }\end{array}$ \\
\hline VII & 26 & 37 \\
\hline VIII & 53 & 48 \\
\hline XIV & 33 & 51 \\
\hline
\end{tabular}


O Gráfico 2, representa a freqüência estimulada dos estadios do ciclo espermatogenético de testículos de ratos pré-púberes estimulados ou não.

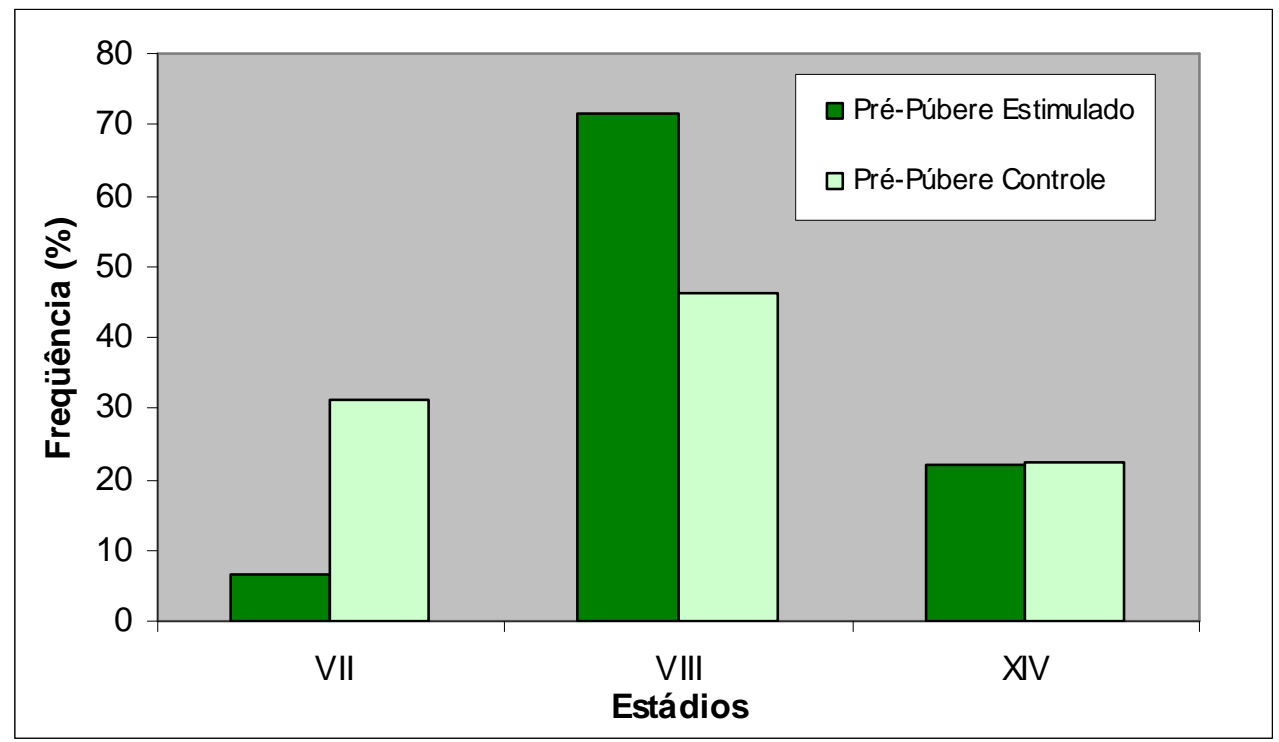

Representação gráfica da freqüência dos estadios VII, VIII e XIV em testículos de animais prépúberes estimulados e não estimulados com ultra-som pulsado de baixa intensidade.

Constata-se um aumento de $(75,67 \%)$ do estádio VIII do ciclo espermatogenético também nos ratos pré-púberes estimulados quando comparados com a de ratos pré-púberes controle.

Tabela 4 - ANOVA $(\alpha=0,05)$ Freqüências dos Estadios do Ciclo Espermatogenético de Ratos Pré-Púberes Estimulados e Ratos Pré-Púberes Controle

\begin{tabular}{|cccccc|}
\hline \multicolumn{7}{|c|}{ FREQUÊNCIA DOS ESTADIOS DE RATOS PRÉ-PÚBERES ESTIMULADOS OU } \\
\hline \multicolumn{7}{c|}{ NÃO. } \\
\hline Estadios & Contagem & Soma & Média & Variância & Desvio padrão \\
\hline VII & 2 & 31 & 15,5 & 180,5 & 13,43 \\
VIII & 2 & 102 & 51,0 & 392,0 & 19,80 \\
XIV & 2 & 38 & 19,0 & 2,0 & 1,41 \\
& \multicolumn{7}{c}{} \\
\hline
\end{tabular}

\begin{tabular}{|c|c|c|}
\hline Estadios & $\begin{array}{c}\text { Pré- } \\
\text { Púbere } \\
\text { Estimulado }\end{array}$ & $\begin{array}{c}\text { Pré- } \\
\text { Púbere } \\
\text { Controle }\end{array}$ \\
\hline VII & 6 & 25 \\
\hline VIII & 65 & 37 \\
\hline XIV & 20 & 18 \\
\hline
\end{tabular}


Expressa o Gráfico 3, os dados da freqüência dos estadios do ciclo espermatogenético nos animais dos diferentes grupos estimulados ou não.

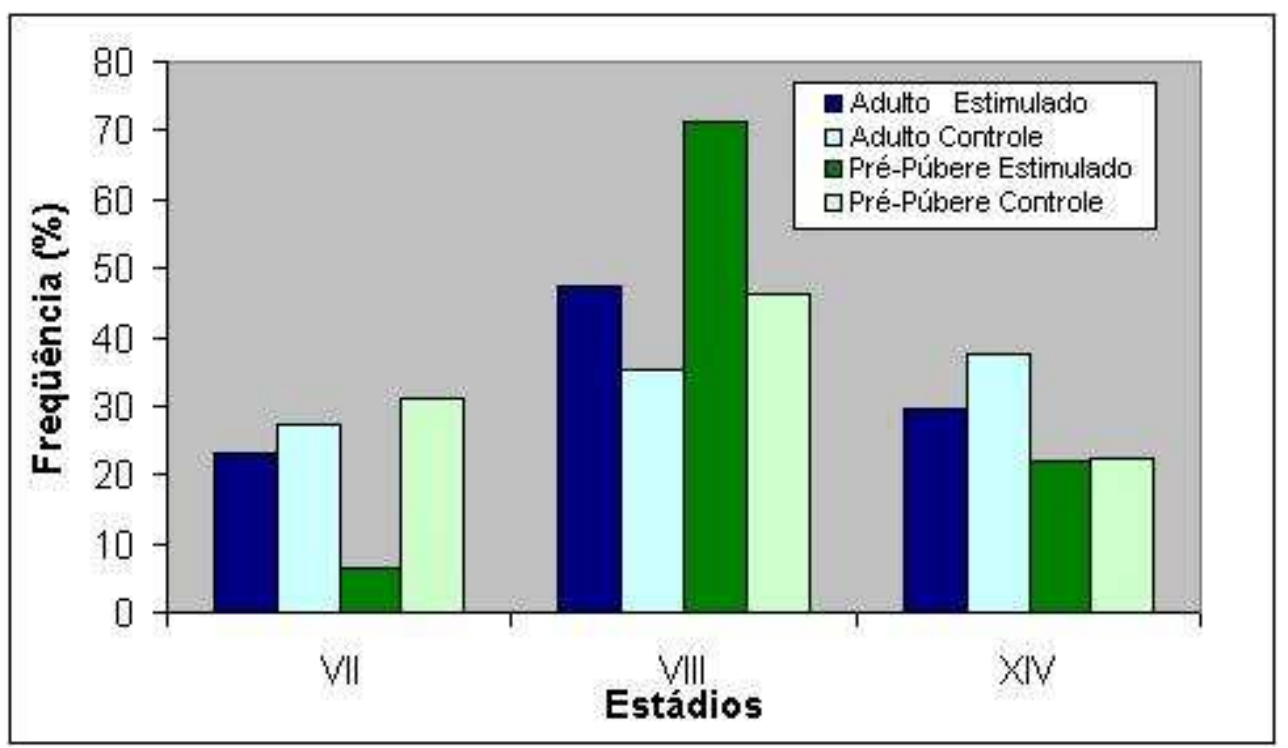

Representação gráfica da freqüência dos estadios VII, VIII e XIV em testículos de animais adultos e pré-púberes estimulados ou não com ultra-som pulsado de baixa intensidade.

Observa-se a freqüência maior do estadio VIII em testículos de ratos prépúberes e adultos estimulados, em comparação à freqüência do estadio VIII do ciclo espermatogenético de testículos de ratos pré-púberes e adultos controles.

Tabela 5 - ANOVA ( $\alpha=0,05)$, Freqüência dos Estadios do Ciclo Espermatogenético de Ratos Pré-Púberes e Adultos Estimulados ou não.

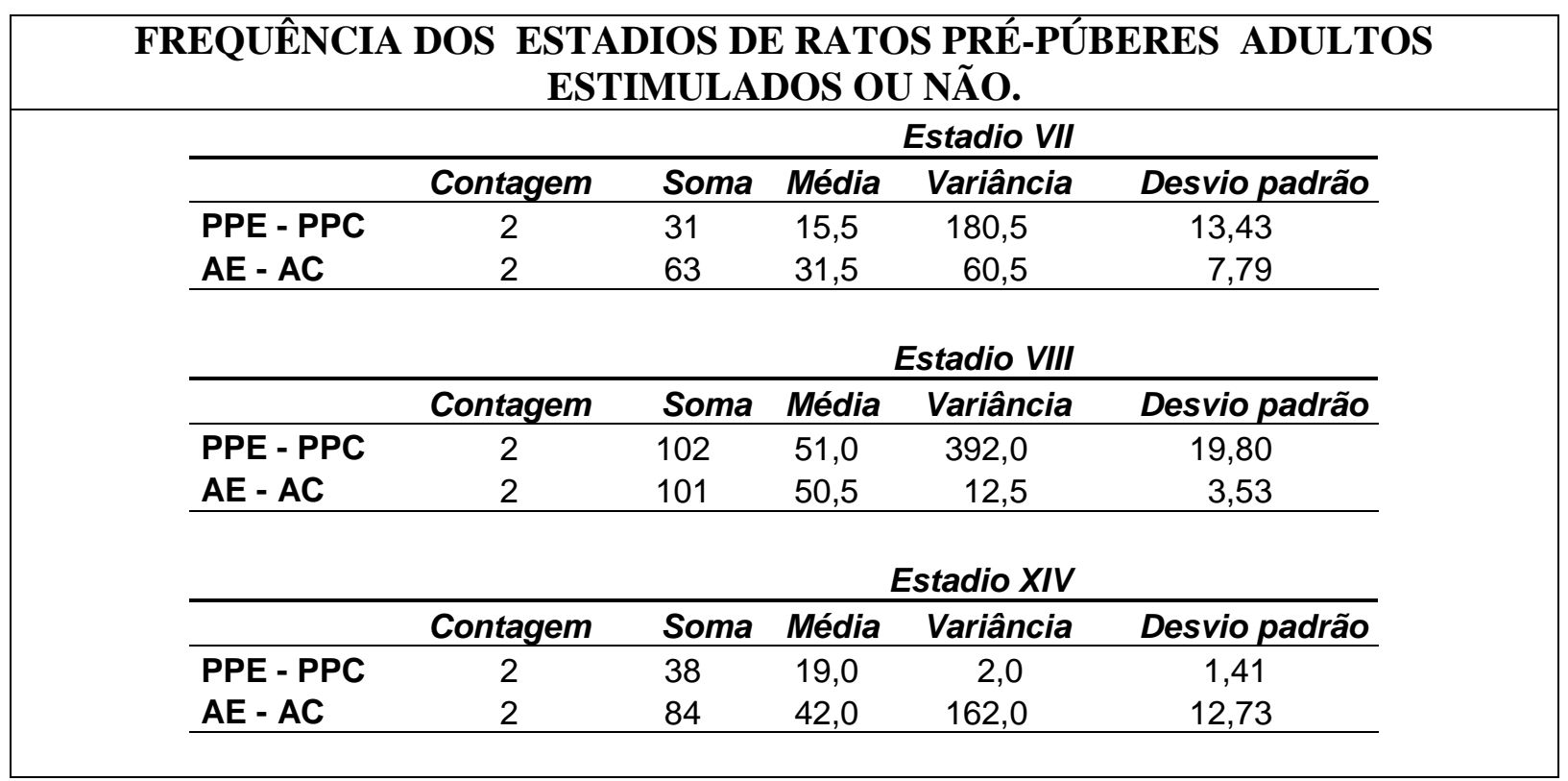


Gráfico 4, representação dos valores da morfometria das áreas dos túbulos e a freqüência das mesmas em testículos de ratos pré-púberes estimulados em comparação com a área de túbulos de ratos não estimulados.

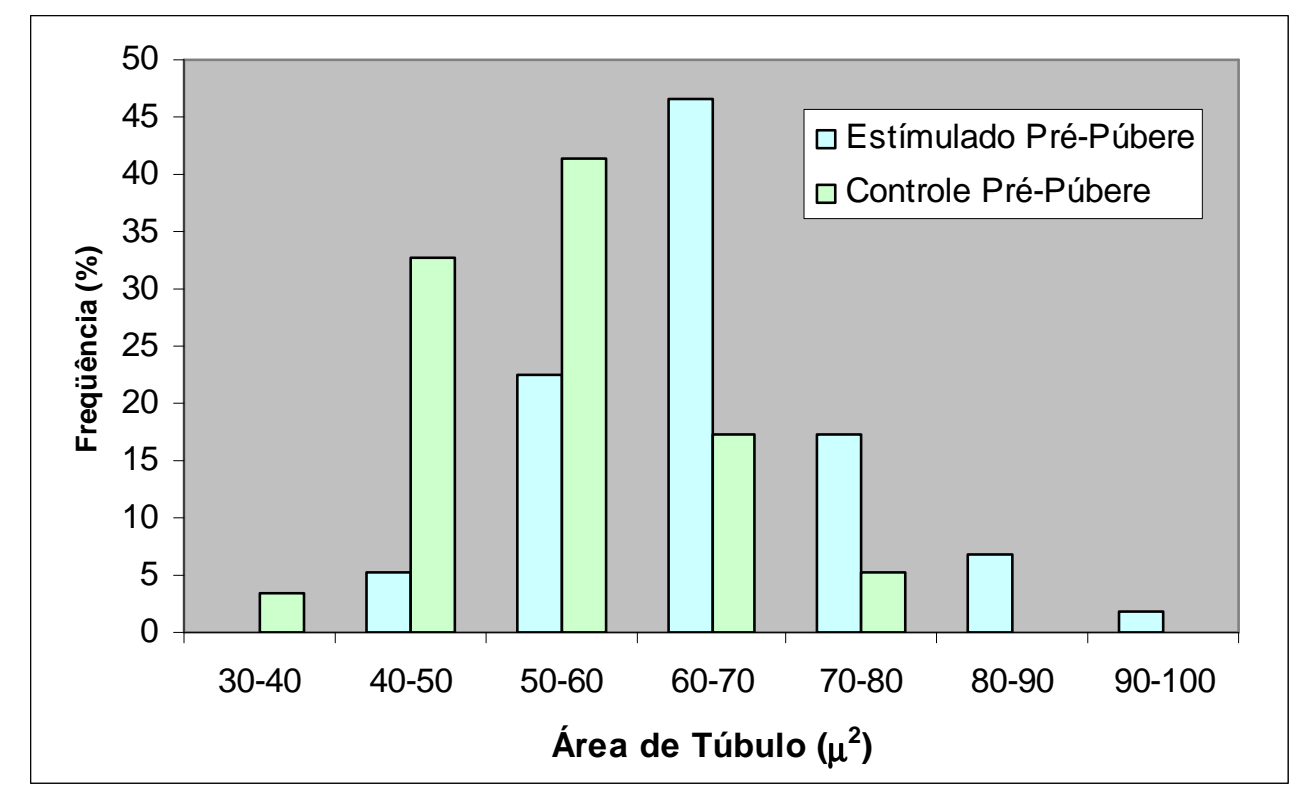

Representação gráfica da morfométria das áreas dos túbulos seminíferos de testículos de ratos pré-púberes estimulados ou não com ultra-som pulsado de baixa intensidade

Constata-se um aumento significativo (22,38\%) na área dos túbulos seminíferos dos testículos de ratos pré-púberes estimulados com ultra-som pulsátil de baixa intensidade. Os dados foram agrupados a intervalos de valores de $10 \mu^{2}$ em $10 \mu^{2}$, iniciando-se com $30 \mu^{2}$ e finalizando com $100 \mu^{2}$ dispostos no eixo horizontal no gráfico, no eixo vertical está representada a percentagem (\%) de freqüência do número total analisado da área dos túbulos.

Tabela 6 - ANOVA $(\alpha=0,05)$ Área dos Túbulos Seminíferos dos Testículos de Ratos Pré-Púberes Estimulados e Controle.

\begin{tabular}{|c|c|c|c|c|c|}
\hline \multicolumn{6}{|c|}{ VALORES DA MORFOMETRIA DAS ÁREAS DE TÚBULOS SEMINÍFEROS DE } \\
TESTÍCULOS DE RATOS PRÉ-PÚBERES ESTIMULADOS E CONTROLE \\
\hline Grupo & $\boldsymbol{N}$ & Soma & Média & Variância & Desvio padrão \\
\hline E-P-P & 58 & 3803,65 & 65,58 & 113,80 & 10,67 \\
\hline C-P-P & 58 & 3108,07 & 53,58 & 81,28 & 9,01 \\
\hline
\end{tabular}


Gráfico 5, representa os valores das áreas dos túbulos e a freqüência das mesmas em testículos de ratos adultos estimulados em comparação com a área de túbulos de ratos não estimulados.

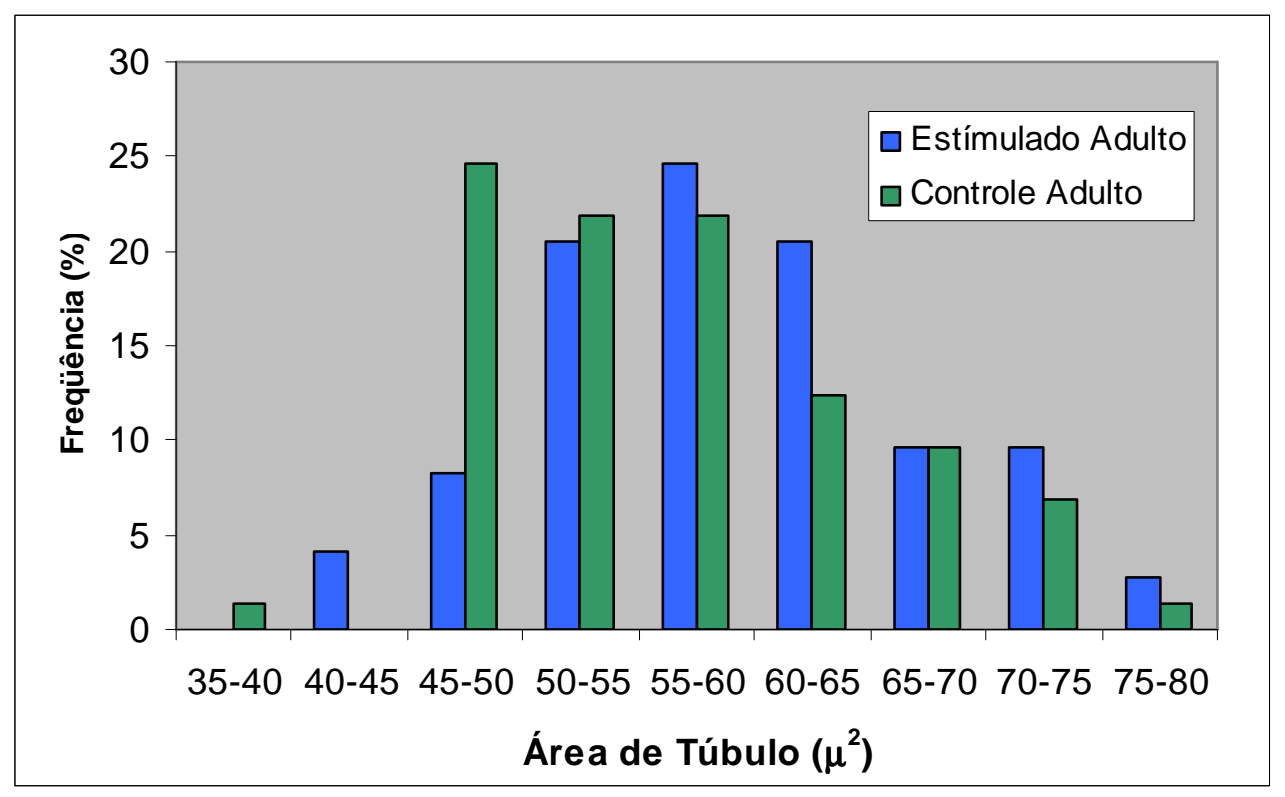

Representação gráfica da morfométria das áreas dos túbulos seminíferos de testículos de ratos adultos estimulados ou não com ultra-som pulsado de baixa intensidade.

No gráfico (5) pode-se constatar um aumento (11.81\%) nas áreas dos túbulos seminíferos dos testículos de ratos adultos estimulados. Os dados agrupados a intervalos de valores de $5 \mu^{2}$ em $5 \mu^{2}$, iniciando com $35 \mu^{2}$ e finalizando com $80 \mu^{2}$ dispostos no eixo horizontal do gráfico, no eixo vertical está representada a percentagem (\%) de freqüência do número total de áreas dos túbulos.

Tabela 7 - ANOVA $(\alpha=0,05)$ Áreas dos Túbulos Seminíferos dos Testículos de Ratos Adultos Estimulados e Controle.

\begin{tabular}{|c|c|c|c|c|c|}
\hline \multicolumn{6}{|c|}{$\begin{array}{c}\text { VALORES DA MORFOMETRIA DAS ÁREAS DE TÚBULOS SEMINÍFEROS DE } \\
\text { TESTÍCULOS DE RATOS ADULTOS ESTIMULADOS E CONTROLES } \\
\end{array}$} \\
\hline Grupo & $N$ & Soma & Média & Variância & Desvio padrão \\
\hline Estimulado Adulto & $\overline{73}$ & 4676,46 & 64,06 & 66,76 & 8,17 \\
\hline Controle Adulto & 73 & 4128,72 & 56,56 & 66,56 & 8,16 \\
\hline
\end{tabular}


Gráfico 6, representa os valores das áreas dos túbulos e a freqüência das mesmas em testículos de ratos adultos estimulados e pré-púberes em comparação com a área de túbulos de ratos não estimulados.

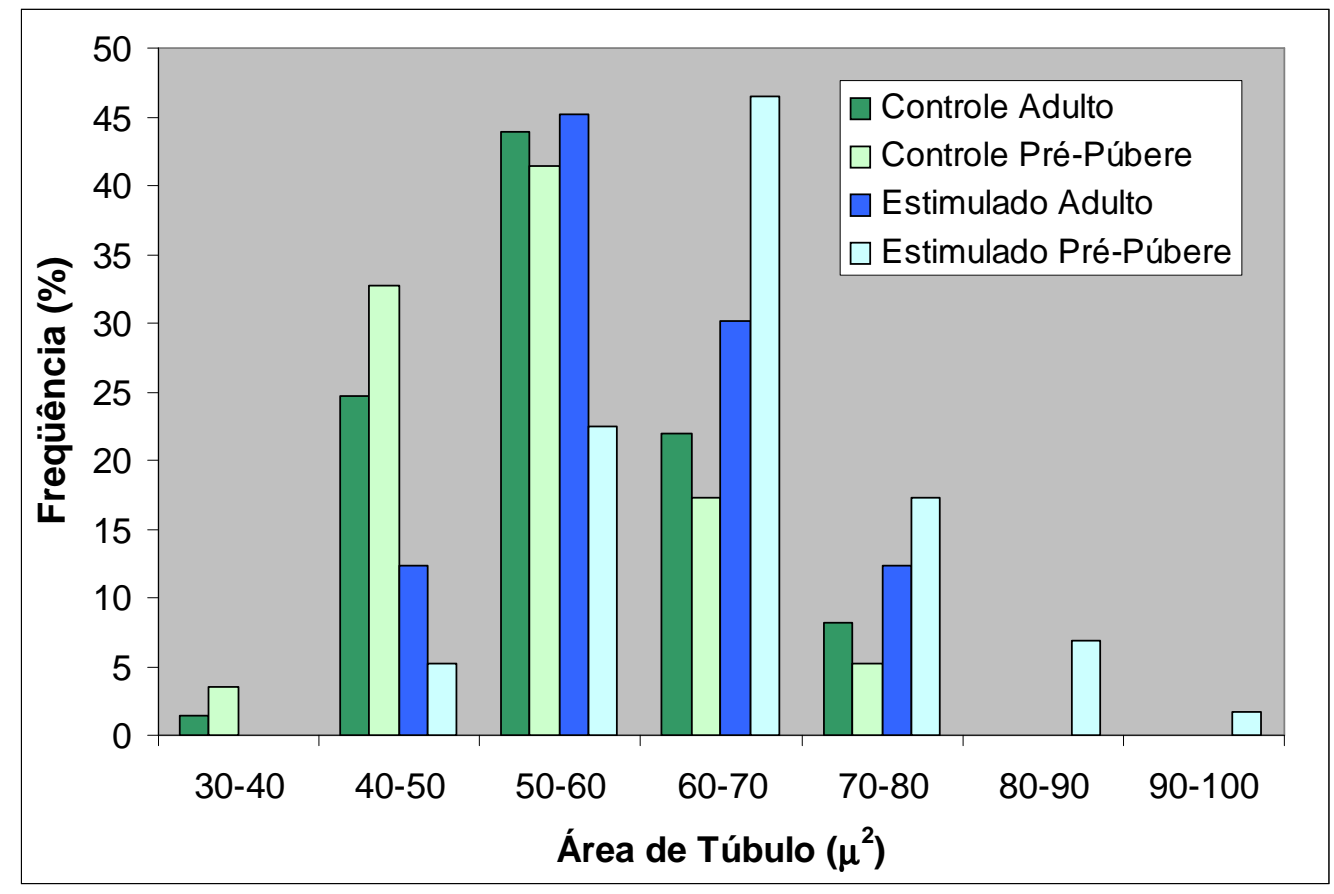

Representação gráfica das áreas dos túbulos seminíferos de testículos de ratos adultos e pré-púberes estimulados ou não com ultra-som pulsado de baixa intensidade

ANOVA $(\alpha=0,05)$ Áreas dos Túbulos Seminíferos dos Testículos de Ratos Adultos e Pré-Púberes Estimulados e Controle.

O gráfico (6) representa um aumento dos valores medidos das áreas dos túbulos seminíferos de testículos de ratos pré-púberes e adultos estimulados com ultra-som pulsátil de baixa intensidade comparando-os com o grupo de animais não estimulados. Os dados foram agrupados a intervalos de valores de $10 \mu^{2}$ em $10 \mu^{2}$, iniciando com $30 \mu^{2}$ e finalizando com $100 \mu^{2}$ dispostos no eixo horizontal do gráfico, no eixo vertical está representada a percentagem (\%) de freqüência do número total analisado da área dos túbulos. 
Gráfico 7, representa os valores do peso dos testículos de ratos adultos estimulados em comparação com o peso dos testículos dos animais não estimulados.

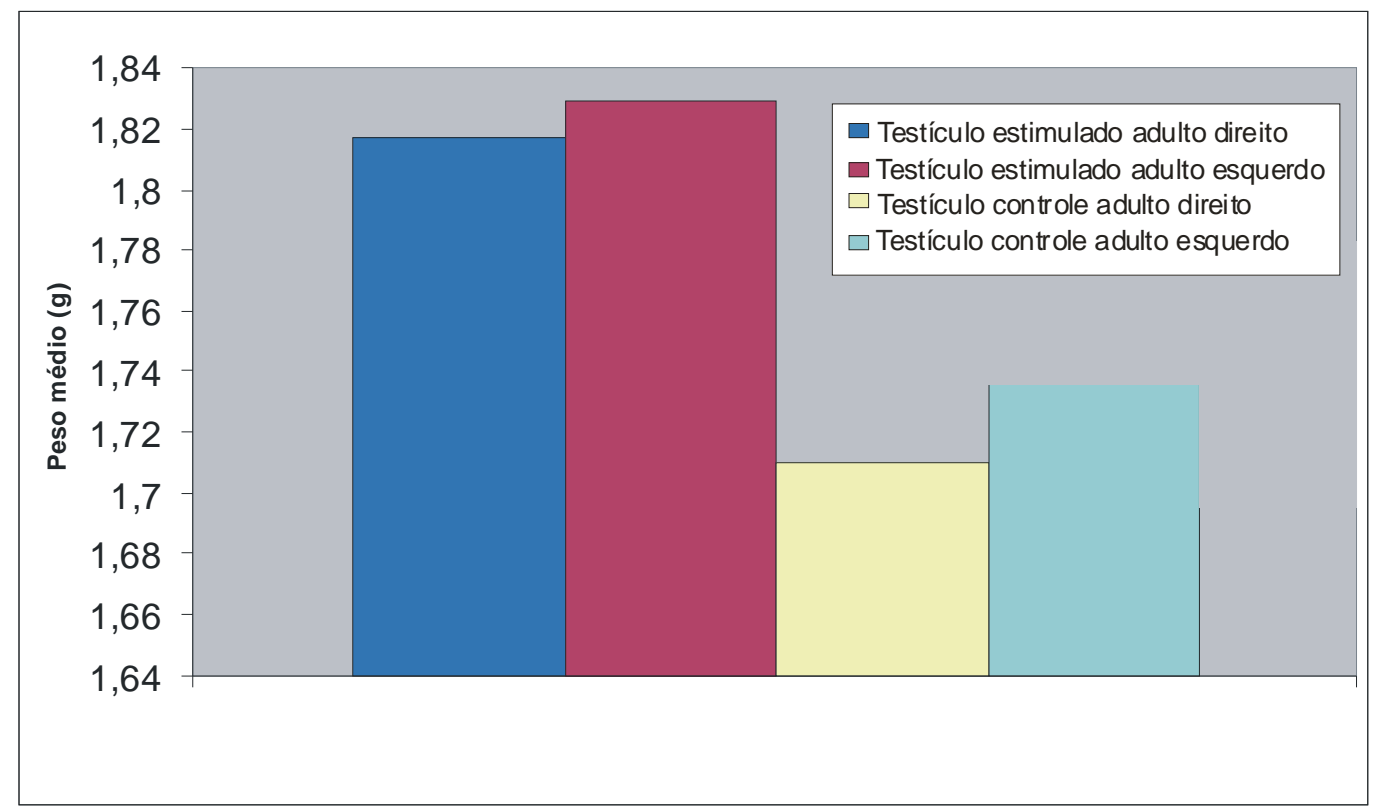

Representação gráfica dos pesos dos testículos de animais adultos estimulados e não estimulados com ultra-som pulsado de baixa intensidade

gráfico (7) representa um aumento $(5,80 \%)$ no peso dos testículos dos ratos adultos estimulados com ultra-som pulsátil de baixa intensidade em comparação aos pesos dos testículos do grupo controle.

Tabela 8 - ANOVA ( $\alpha=0,05)$, Peso dos Testículos de Ratos Adultos Estimulados e Controle.

\begin{tabular}{|c|c|c|c|c|c|}
\hline \multicolumn{6}{|c|}{ TESTÍCULO DE RATO ADULTO ESTIMULADO DIREITO E ESQUERDO } \\
\hline Grupo & $\boldsymbol{N}$ & Soma & Média & Variância & Desvio padrão \\
\hline T E D & 10 & 18,17 & 1,81 & 0,00 & 0,06 \\
\hline T E E & 10 & 18,29 & 1,82 & 0,00 & 0,07 \\
\hline \multicolumn{7}{|c|}{ TESTÍCULO DE RATO ADULTO CONTROLE DIREITO E ESQUERDO } \\
\hline Grupo & $\mathbf{N}$ & Soma & Média & Variância & Desvio padrão \\
\hline T C D & 10 & 17,10 & 1,71 & 0,01 & 0,11 \\
\hline T C E & 10 & 17,36 & 1,74 & 0,00 & 0,10 \\
\hline
\end{tabular}




\section{6 - Discussão}

Nesta pesquisa procurou-se estimar morfometricamente, as áreas dos túbulos seminíferos, bem como a dinâmica do ciclo espermatogenético no testículo de ratos na pré-puberdade e de ratos adultos com a finalidade de constatar eventuais efeitos da aplicação de radiação ultra-sônica. Esta avaliação foi baseada na estimativa do comportamento dos ciclos espermatogenéticos identificando os estadios inicias (XIV) e finais (VII e VIII). Estimaram-se também os pesos dos testículos dos ratos adultos submetidos ou não à estimulação ultra-sônica. Os valores obtidos para as áreas dos túbulos de testículos estimulados ou não foram também avaliados estatisticamente.

Dentre os inúmeros benefícios do Ultra-som Pulsado de Baixa Intensidade, destacou-se a capacidade na transformação de cartilagem em osso primário, acelerando a consolidação de pseudo-artroses (DUARTE, 1977, 1983), como a primeira ação biológica demonstrada, com a aplicação do Ultra-som Pulsado.

Não há dúvidas, hoje em dia, sobre os seus efeitos benéficos na produção e aceleração de reparos em fraturas ósseas, induzidas experimentalmente ou sobre pseudo-artroses, para a qual fora inicialmente indicado.

Experimentos posteriores realizados com o Ultra-som mostraram interação deste tipo de radiação sobre outros tecidos biológicos.

Independentemente dos mecanismos mediante os quais os estímulos produzidos pelo Ultra-som Pulsado atuam sobre outros tecidos biológicos, o objetivo principal desta investigação é o de verificar os efeitos desse tipo de radiação ultrasônica em um processo biológico, repetitivo e regulado pela intermitência de secreções hormonais, como o da espermatogênese do rato. Já foi demonstrado clinicamente que a terapia com o Ultra-Som Pulsado promove a cicatrização de úlceras cutâneas conseqüentes a diversos fatores (PAUL, COLS, 1.960; GALITSKY, LEVINA, 1964). 
Como também a eficácia do tratamento com Ultra-som em úlceras varicosas crônicas (DYSON, COLS. 1976); DYSON, SUCKLING, 1978).

Esses mesmos autores constataram que a área ulcerada após aplicação do Ultra-som exibia intensa formação de tecido de granulação e estimulava também a reepitelização do tegumento sobre a área da úlcera.

É importante notar que o Ultra-som exibe ação pró-inflamatória, pois vários tipos de tecidos submetidos a lesões experimentais mostraram aumento do número de células na fase proliferativa no leito da ferida (LEFAUCHER, SÉBILLE, 1995; KOKUBU et al., 1999).

(KOKUBU et al, 1999), demonstraram que o Ultra-som aumentou a produção de prostaglandina via indução da ciclooxigenase I e II, e assim o Ultra-som atuaria na fase inflamatória mobilizando macrófagos, mastócitos e neutrófilos, acelerando a resolução normal da inflamação. Este fato ocorreria pelo aumento na velocidade de mobilização celular em função da movimentação do líquido intersticial aumentando a taxa de fagocitose bem como o movimento de partículas e células, com a liberação de mediadores químicos como a histamina e a serotonina no processo inflamatório.

O estímulo induzido pelo Ultra-som Pulsado de Baixa Intensidade leva à formação do tecido de granulação, bem como a reepitelização de lesões cutâneas (KOKUBU et al, 1999); BAKER et al, 2001),

Por tratar-se de método não invasivo o Ultra-som Pulsado de Baixa Intensidade, torna-se recurso de grande valia para utilização na medicina (MAYER et al, 2000).

Os fibroblastos podem ser estimulados a produzir um aumento na síntese de colágeno devido ao aumento na permeabilidade da membrana celular, havendo também a estimulação da angiogênese, caracterizados pelo um aumento de capilares no leito da ferida, estimulando assim a cicatrização da ferida (TIS et al, 2001),

(TIS et al, 2001), confirmaram que o Ultra-som aumenta o número de células no leito da ferida promovendo estímulo à cicatrização.

(DUCK et al, 2001), mostraram IN VITRO a degranulação de mastócitos a qual estaria relacionada com o aumento passivo da permeabilidade das membranas celulares em virtude da liberação local de histamina.

(ROBERTSON et al, 2001), consideraram que possivelmente devido ao mecanismo benéfico da cavitação, as partículas poderiam sofrer pequenas vibrações 
devido à passagem da onda ultra-sônica pelo tecido (dependente da pressão e da intensidade). Conseqüentemente, quando a oscilação é pequena, ela não pode ser responsável pelos danos celulares. Há referências de alteração na membrana plasmática e organelas intracelulares como as dos lisossomos.

(GEBEAUER et al, 2002), demonstraram experimentalmente a efetividade do Ultra-som no reparo de fraturas mesmo em condições adversas como em animais nos quais foi induzido experimentalmente o Diabetes Mellitus.

(ZHANG et al, 2003), estimaram que o Ultra-Som Pulsado de Baixa Intensidade não causa dano à célula. Os resultados apontam que os produtos dos radicais livres são responsáveis por efeitos biológicos na estimulação do gene.

(SPENCER et al, 2003), estes pesquisadores aplicaram as técnicas do Ultrasom pulsado de baixa intensidade no transporte de drogas, processo conhecido como sonoforese. Esta técnica usa o Ultra-som em lugar de agulhas para transportar drogas como insulina e interferon via transcutânea. O Ultra-som pode abrir poros minúsculos na membrana celular, aumentando a permeabilidade celular, melhorando a penetração das drogas. Este fenômeno aumenta o efeito da droga, reduzindo a toxicidade, e levando a droga para áreas restritas do corpo agindo de maneira localizada.

(FRANCOMANO et al, 2003), em estudo tentaram aplicar os efeitos biológicos da porosidade da membrana celular produzida pelo Ultra-Som Pulsado de Baixa Intensidade. Examinaram parâmetros da permeabilidade da membrana celular, e mudanças nas enzimas, características morfológicas, e outros fatores de dano durante a estimulação ultra-sônica.

Diante das pesquisas mencionadas e as variadas ações e mecanismos do Ultra-som Pulsado sobre diferentes tecidos, acabaram por estimular esta investigação.

São pouquíssimos os trabalhos na Literatura que relacionam o uso do UltraSom Pulsado de Baixa Intensidade e este tipo de radiação sobre processos biológicos mais complexos como a espermatogênese ou a ovogênese.

Os mecanismos pelos quais o Ultra-som atuaria sobre tecidos ou lesões provocadas experimentalmente, modificando por cavitação ou outro mecanismo qualquer o metabolismo de células e seus meios foi à razão pela qual foi proposto 0 estudo da espermatogênese do rato. 
Esta escolha baseia-se no fato de que a relação entre as células e a dinâmica do ciclo espermatogenético são altamente interdependentes. O mecanismo dinâmico do ciclo poderia ser investigado a fim de se avaliar os eventuais efeitos da radiação ultra-sônica sobre a espermatogênese.

(HADDAD, 1992), foi um dos poucos autores que pesquisou o efeito do Ultrasom sobre testículos de ratos pré-púberes, púberes e adultos, com a finalidade de estudar as atividades androgênicas e espermatogenéticas bem como outros parâmetros hormonais que pudessem expressar eventuais efeitos do Ultra-som sobre o processo da espermatogênese e androgênese.

O Ultra-som não estimulou a proliferação celular do epitélio germinativo não alterando mitoses de espermatogonias e a produção de espermatozóides, avaliada por sua concentração na cauda do epidídimo. Embora este tipo de avaliação seja presuntivo, pois o rato exibe uma grande quantidade de espermatozóides no ejaculado, tornando difícil à avaliação histológica ou quantitativa da produção de espermatozóides.

A mesma autora admite que seus resultados permitem concluir que, se por um lado o tratamento com o ultra-som pulsado de baixa intensidade, utilizado maneira semelhante ao que foi aqui utilizado, não estimula a espermatogênese, provoca, porém um aumento significativo na atividade androgênica em ratos prépúberes.

O índice plasmático de testosterona aumentou $63 \%$ favorecendo 0 crescimento e a atividade secretora da vesícula seminal, na pré-puberdade e a transformação morfológica de células haplóides em espermatozóides maduros.

Estes fatos levaram à execução desta pesquisa para a constatação desses fatos em relação à espermatogênese.

Nossos achados mostraram variações significativas no número de estadios VIII, que representam no ciclo espermatogenético a maturidade final de espermatozóides. Constatou-se também variações no peso de testículos de ratos adultos estimulados.

A avaliação do ciclo seria compatível com uma aceleração da onda espermatogenética pelo aumento do número de estadios VIII, sem que houvesse aumento simultâneo do estadio XIV, mostrando a não interferência com as mitoses 
reducionais, mas o estimulo na progressão da maturidade dos espermatozóides interferindo na velocidade da espermiogênese.

(HADDAD, 1992), constatou também que o peso dos testículos de ratos adultos estimulados e não estimulados com Ultra-som não apresentaram variações.

Os resultados obtidos na presente investigação mostraram de que o Ultrasom Pulsado de Baixa Intensidade produz aumento significativo no peso dos testículos de ratos adultos estimulados.

A mesma autora pesquisou a dinâmica do processo espermatogenético, avaliando as freqüências dos estádios VII, VIII e XIV do ciclo espermatogenético em ratos adultos estimulados e não estimulados com Ultra-som Pulsado de Baixa Intensidade, admitindo não haver alterações na dinâmica do ciclo espermatogenético entre os dois grupos experimentais.

Constatou também que o testículo e o epidídimo, quando submetidos à ação direta da energia ultra-sônica, não apresentaram quaisquer alterações que pudessem ser observados à microscopia óptica, tanto no testículo quanto no epidídimo de ratos pré-púberes estimulados e não estimulados.

E também que os testículos de ratos pré-púberes estimulados e não estimulados com Ultra-som não apresentaram diferenças na espermatogênese que pudessem ser caracterizadas como decorrentes da estimulação. Afirma a mesma autora no exame histológico de testículos que o ciclo espermatogenético de ratos adultos estimulados com Ultra-som não revelou modificações atribuíveis à estimulação ultra-sônico.

Entretanto, sem explicações, observou túbulos seminíferos com espermatozóides maduros em vias de serem encaminhadas para o epidídimo e em cortes de epidídimo grandes quantidades de espermatozóides.

As afirmações da autora poderiam estar relacionadas a um aumento na dinâmica do ciclo ou na onda espermatogenética levando a uma maior produção de espermatozóides jovens prontos a serem liberados na luz tubular.

Nossos achados caracterizando e avaliando numericamente os estadios VII e VIII do ciclo permitiriam explicar esses achados citados pela autora. Nossas observações, mediante as avaliações quantitativas, explicariam o aumento de espermatozóides maduros preenchendo o epidídimo.

(LAMANO et al, 1985), descreveram semelhante achado, ou seja, um aumento na freqüência de estadios VII e VIII quando da administração crônica do 
HCG em ratos submetidos a uma denervação dos testículos pela fenolização do cordão espermático avaliando a freqüência dos estadios VII e VIII, como aceleração da espermatogênese.

Nossos resultados mostraram o aumento das áreas dos túbulos seminíferos dos testículos dos ratos adultos e pré-púberes estimulados quando comparadas às áreas tubulares de ratos controle. Constatou-se também uma considerável diferença na freqüência dos estádios finais (VII e VIII) e iniciais (XIV) do ciclo espermatogenético de ratos adultos e ratos pré-púberes estimulados em comparação aos estadios dos ciclos de animais não estimulados. Esses achados nos permitem admitir que o Ultra-som acelera a onda espermatogenética em testículos de animais pré-púberes e adultos, pela predominância do estádio VIII do ciclo espermatogenético, indicativos da influência na espermiogênese acelerando a maturidade dos espermatozóides.

Como se trata de método não invasivo poder-se-ia aventar da possibilidade de aplicação do Ultra-som Pulsado de Baixa Intensidade em caso de subfertilidade ou de incapacitação de espermatozóides.

Não fizemos a avaliação das mitoses de espermatogonias durante os ciclos espermatogenéticos, mas nossos achados mostram que a ação do Ultra-som Pulsado de Baixa Intensidade teria influência na dinâmica da espermiogênese e conseqüentemente na onda espermatogenética. 


\section{7 - Conclusão}

Os resultados obtidos, mediante a metodologia utilizada, permitiram admitir que o Ultra-som Pulsado de Baixa Intensidade atua diretamente no ciclo espermatogenético do testículo de ratos adultos e pré-púberes, modificando a velocidade.

A fase de espermiogênese com conseqüente aumento na maturação de espermatozóides, constatando também aumento da área dos túbulos seminíferos.

Os pesos dos testículos de ratos adultos estimulados foi maior que o de testículos de ratos não estimulados. 


\section{8 - Referências Bibliográficas}

ALVES, J.M. (1988). Efeitos da energia ultra-sônica na regeneração de pele animal com queimaduras com calor. 70p. Dissertação (Mestrado) - Programa de Interunidades em Bioengenharia - EESC/FMRP/IQSC, Universidade de São Paulo, São Carlos, 1988.

ALBERTIN, L.M. (1983). Efeito do ultra-som no reparo de falha óssea experimental: avaliação quantitativa e morfológica do parâmetro tempo de estimulação. 44p. Dissertação (Mestrado) - Programa de Interunidades em Bioengenharia - EESC/FMRP/IQSC, Universidade de São Paulo, São Carlos, 1983.

APFEL, R.E. (1982). Acoustic cavitation: a possible consequence of biomedical uses of ultrasound. British Journal of Cancer, London, v.45, p.140-175.

BAKER, K.G.; ROBERTSON, V.J.; DUCK, F.A. (2001). A review of therapeutic ultrasound: biophysical effects. Physical Therapy, Chicago, v.81, n.7, p.1351-1358, July.

CARDOSO, A.M.C. (1985). Estudo sobre os cromossomos metafásicos de células de medula óssea expostas in vivo ao ultra-som pulsado como estímulo de crescimento ósseo. 105p. Dissertação (Mestrado) - Programa de Interunidades em Bioengenharia - EESC/FMRP/IQSC, Universidade de São Paulo, São Carlos, 1985.

CARDOSO, F.M. (1981). Morfologia, cinética e quantificação da espermatogênese em zebus (Boss indicus). 208p. Tese (Doutorado) - Instituto de Ciências Biológicas, Universidade Federal de Minas Gerais, Belo Horizonte, 1981.

CLERMONT, Y. (1962). Quantitative analysis of spermatogenesis of the rat: a revised model for the renewal of spermatogonia. American Journal of Anatomy, Lancaster, v.111, p.111-129.

CLERMONT, Y.; HARVEY, S.C. (1952). Effects of hormones on spermatogenesis in the rat. Endocrinology, Springfield, v.16, p.173-196. 
CLERMONT, Y.; MORGENTALER, H. (1955). Quantitative study of spermatogenesis in the hypophysectomized rat. Endocrinology, Springfield, v.57, n.3, p.369-382, Sept.

CRISCI, A.R. (2001). Estudo experimental dos efeitos do Ultra-som pulsado de baixa intensidade sobre a regeneração do nervo ciático de ratos após neurotomia, mediante avaliações morfológicas e morfométricas. 100p. Dissertação (Mestrado) - Programa de Interunidades em Bioengenharia EESC/FMRP/IQSC, Universidade de São Paulo, São Carlos, 2001.

DUARTE, L.R. (1977). Estimulação ultra-sônica do calo ósseo. 109p. Tese (Livre Docência) - Escola de Engenharia de São Carlos, Universidade de São Paulo, São Carlos, 1977.

. (1983). The stimulation on of bone growth by ultrasound. Archives of Orthopaedic and Traumatic Surgery, Munchen, v.101, n.3, p.153-159, Apr.

DUCK, A. et al. (2001). A review of Therapeutic Ultrasound. Biophysycal Effects. Physical Therapy. Vol 81 number 7, (2001).

DYM, M.; CLERMONT, Y. (1970). Role of spermatogonia in the repair of seminiferous epithelium following $x$ - irradiation of the rat testis. American Journal of Anatomy, Lancaster, v.128, p.265-282.

DYSON. M. (1985). Therapeutic applications of ultrasound. In: NYBORF W. L. ZISKIN, M. C. Biological effects of ultrasound: clinics in diagnostics ultrasound. Edinburgh, Churchill Livingstone, 1985. p 121-133.

DYSON, M. (1987). Mechanisms involved in therapeutic ultrasound. Physiotherapy, London, v.73, n.3, p.116-120, Mar.

DYSON, M.; PAOOKES, M. (1983). Stimulation of bone repair by ultrasound. Ultrasound in Medicine \& Biology, Elmsford, supl, 2, p.61-66.

DYSON, M.; SUCKLING. J. (1978). Stimulation of tissue repair by ultrasound a survey of the mechanisms involved. Physiotherapy, London, v.64, n.4, p.105-108, Apr.

DYSON, M. et al. (1968). The stimulation of tissue regeneration by means of ultrasound. Clinical Science, Oxford, v.35, n.2, p.273-285.

FERRARI, A.L. (1987). Estudos dos mecanismos de cavitação em meio biológico. 133p. Dissertação (Mestrado) - Programa de Interunidades em Bioengenharia - EESC/FMRP/IQSC, 1987.

FERREIRA, A.L. (1962). Estudo cariométrico da espermatogênese do rato. 53p. Tese (Doutorado) - Faculdade de Medicina de Ribeirão Preto, Universidade de São Paulo, Ribeirão Preto, 1962. 
FRANCOMANO, A., et al. (2003): The influence of pulsed low-intensity ultrasound on matrix production of chondrocytes at different stages of differentiation: An explant study. Ultrasound in Med \& Biol., Vol 28, Nos. 11/12, pp. 1547-1553, 2002.

FRIZZEL, L.A.; DUNN, F. (1984). Biophysics of ultrasound. In: LEHMAN, J.F. Therapeutic heat and cold. 3.ed. London: Williams \& Wilkins. Cap.8/10, p.353562.

FUKADA, E.; YASUDA, I. (1957). On piezoelectric effect of boné. Journal of Physical Society of Japan, Tokyo, v.12, n.10, p.1152-1162, Oct.

GALITSKY, A.B.; LEVINA, S.I. (1964). Vascular origin of trophic ulcers and application of ultrasound as pré operative treatment to plastic surgery. Acta Chirurgica Plastics, v.6, p.271-278.

GEBEAUER, G. et al. (2002). Low-intensity pulsed ultrasound increases the fracture callus strength in diabetic BB Wistar rats but does not affect cellular proliferation. Journal of Orthopaedic Research, New York, v.20, n.3, p.587-592, May.

GONZÁLEZ, H.D.F. (2002). Introdução à endocrinologia reprodutiva veterinária. Porto Alegre: Universidade Federal do Rio Grande do Sul.

HADDAD, S. (1992). Estímulo do testículo de ratos pré-púberes, púberes e adultos com ultra-som pulsado de baixa intensidade. 93p. Dissertação (Mestrado) - Programa de Interunidades em Bioengenharia - EESC/FMRP/IQSC, Universidade de São Paulo, São Carlos, 1992.

HWANG, H. J. (2004). Vascular effects induced combined 1-MHz ultrasound and microbubble contrast agent treatments in vivo. Ultrasound in Med. \& Biol.Vol 31. № 4 pp. 553-564. 2005.

HILÁRIO, M. (1993). Radiação ultra-sônica de baixa intensidade na reparação tecidual de úlceras tróficas de perna. 153p. Dissertação (Mestrado) - Programa de Interunidades em Bioengenharia - EESC/FMRP/IQSC, Universidade de São Paulo, São Carlos, 1993.

HILL, C.R. (1971). Ultrasonic exposure threshold for changes in cell and tissues. Journal of the Acoustical Society of Previus, p.667-672, July. . (1972). Ultrasonic exposure threshold for changes in cell and tissues. Journal of the Acoustical Society of America, New York, v.52, n.23, p.667-672, Aug.

HURME, T.; KALIMO, H. (1992). Activation of my organic precursor cells after muscle injury. Medicine and Science in Sports and Exercise, Madison, v.24, n.2, p.197-205.

ITO, M. et al. (2000). Effects of ultrasound and 1, 25 dihydroxyvitamin D 3 on growth factor secretion in co-cultures of osteoblasts and endothelial cells. Ultrasound in Medicine Biology, Elmsford, v.26, n.1, p.161-166, Jan. 
KOKUBU, T. et al. (1999). Low intensity pulsed ultrasound exposure increases prostaglandin E2 production via the induction of cyclooxygenase 2 mRNA in mouse osteoblasts. Biochemical Biophysical Research Communications, New York, v.256, n.2, p.284-287, Mar.

LAMANO, T.L.C. (1985). Avaliação da freqüência de fases VII, VIII e XIV do ciclo tubular de ratos adultos após administração crônica do HCG. Anatomischer Anzeiger, Jena, v.159, p.33-41, Dez.

LEBLOND. C. P. CLERMONT. Y. (1952). Spermiogenesis of rat, mouse, hamster and guinea pig as revealed by the "periodic acid-fuchsin sulfurous acid" techinique. American Journal of Anatomy, v.90, p 167-215, 1952.

LEFAUCHER, J.P.; SÉBILLE, A. (1995). The cellular events of injured muscle regeneration depend on the nature of injury. Neuromuscular Disorders, Oxford, v.5, n.6, p.501-509, Nov.

LEITE, A.J. (1989). Quantificação da ruptura celular produzida por ultra-som em eritrócitos do sangue humano. 125p. Dissertação (Mestrado) - Faculdade de Filosofia, Ciências e Letras, Universidade de São Paulo, Ribeirão Preto, 1989.

MACHEN, S., M. et al. (2002). The effect of low intensity pulsed ultrasound applied to rabbit tibiae during the consolidation phase of distraction osteogenesis. Journal of Orthopaedic Research 20 (2002) 793-800.

MASON, W.P. (1981). Piezoelectricity, its history and applications. Journal of the Acoustial Society of America, New York, v.70, n.6, p.1561-1566, Dec.

MAYER, E. et al. (2000). Does low intensity, pulsed ultrasound speed healing of scaphoid fractures. Handchirurgie, Mikrochirurgie, Plastische Chirurgie, New York, v.32, n.2, p.115-122, Mar.

MOTIMER JR., A.; DYSON, M. (1988). The effects of therapeutic ultrasound on calcium up take in fibroblasts. Ultrasound in Medicine and Biology, Elmsford, v.14, n.6, p.499-506

NARUSE, K. et al. (2000). Anabolic response of mouse bone-marrow-derived stromal cell clone STZ cells to low-intensity pulsed ultrasound. Biochemical and Biopshysical Research Communications, New York, v.268, n.1, p.216-220, Feb.

NYBORG, L. (1982). Ultrasonic micro streaming an related phenomena. British Journal of Cancer, London, v.45, p.156-160.

. (2001). Biological effects of ultrasound: development of safety guidelines part II - general review. Ultrasound in Medicine \& Biology, Elmsford, v.27, n.3, p.301-333, Mar.

OKUNO, E.; CALDAS, I.L.; CHOW, C. (1982). Física para ciências biológicas e biomédicas. São Paulo: Harper \& Row do Brasil. Cap.16, p.238-250. 
Harba.

. (1986). Física para ciências biológicas e biomédicas. São Paulo:

PAUL, B.J. et al. (1960). Use of ultrasound in the treatment of pressure sores in patients with spinal cord injury. Archives of Physical Medicine and Rehabilitation, Chicago, v.41, p.438-440.

ROBB, G.W.; AMANN, R.P.; KILLIAM, G.J. (1978). Daily sperm production and epididymal sperm reserves of pubertal and adult rats. Journal of Reproduction and Fertility, Oxford, v.54, p.103-107.

ROBERTSON, J. (2001): A review of Therapeutic Ultrasound. Biophysycal Effects. Physical Therapy. Vol 81 number 7, (2001).

SARVAZYAN, A.P. (1983). Some general problems of biological action of ultrasound. IEEE Transactions on Sonics and Ultrasonic, New York, v.30, n.1, p.2-12, Jan.

SILVA, O.L. (1987). Estudo do mecanismo de ação do ultra-som na estimulação do crescimento ósseo. 209 p. Dissertação (Mestrado) - Programa de Interunidades em Bioengenharia - EESC/FMRP/IQSC, Universidade de São Paulo, São Carlos, 1987.

SPENCER G. S. et al. (2003): The influence of pulsed low-intensity ultrasound on matrix production of chondrocytes at different stages of differentiation: An explant study. Ultrasound in Med \& Biol., Vol 28, Nos. 11/12, pp. 1547-1553, 2002.

TER HAAR, G. (1987a). Physic of therapeutic ultrasound. Physiotherapy, London, v.73, n.3, Mar.

. (1987b). Tissue regenerations. In: REPACHOLI, M.H. et al. Ultrasound medical applications, biological effects and hazard potential. New York: Plenum Press.

TEER HAAR, G. (1978). Basicphysies of therapeutic ultrasound. Physiotherapy, London, v.73, n.3, p.110-113.

TER HAAR, G. et al. (1982). Ultrasonically induced cavitations in vivo. British Journal of Cancer, London, v.45, n.5, p.151-155.

TIS, E. et al. (2001). The effect of low intensity pulsed ultrasound applied to rabbit tibiae during the consolidation phase of distraction osteogenesis. Journal of Orthopaedics Research, New York, v.20, n.4, p.793-800, July.

VALENTINE, E.A. (2006). Avaliação do campo acústico gerado pelos aparelhos de ultra-som terapêutico do programa de pós-graduação interunidades em bioengenharia de acordo com a norma NBR-IEC 1689. 97p. Dissertação (Mestrado) - Programa de Interunidades em Bioengenharia - EESC/FMRP/IQSC, Universidade de São Paulo, São Carlos, 2006. 
XAVIER, C.; DUARTE, L.R. (1983). Estimulação ultra-sônica do calo ósseo. Revista Brasileira de Ortopedia, Belo Horizonte, v.18, n.3, p.73-80, maio/jun.

WELLS, P.N.T. (1977). Biomedical ultrasonic. London: Academic Press.

YOUNG, S.R. (1990). The effect of therapeutic ultrasound on the biological mechanisms involved in dermal repair. London: University London.

ZHANG, J. et al. (2002). The influence of pulsed low-intensity ultrasound on matrix production of chondrocytes at different stages of differentiation: an explant study. Ultrasound in Medicine \& Biology, Elmsford, v.28, n.11/12, p.1547-1553, Nov./Dec.

. (2003). The effects of pulsed low-intensity ultrasound on chondrocyte viability proliferation, gene expression and matrix production. Ultrasound in Medicine \& Biology, Elmsford, v.29, n.11, p.1645-1651, Nov. 
9 - Apêndice Áreas dos Túbulos Seminíferos dos Testículos de Ratos Pré-Púberes Estimulados e
Controle

\begin{tabular}{|c|c|c|c|}
\hline$E P P\left(\square^{2}\right)$ & $C \operatorname{PP}\left(\square^{2}\right)$ & $S Q E P P$ & $S Q C P P$ \\
\hline 65,659 & 52,386 & 0,006241 & 1,443602 \\
\hline 79,717 & 55,998 & 199,8548 & 5,81051 \\
\hline 63,303 & 58,747 & 5,184729 & 26,62044 \\
\hline 72,57 & 48,38 & 48,8601 & 27,11806 \\
\hline 83,566 & 58,904 & 323,4962 & 28,26517 \\
\hline 64,795 & 57,225 & 0,616225 & 13,23141 \\
\hline 60,868 & 34,636 & 22,20294 & 359,1594 \\
\hline 68,172 & 37,934 & 6,718464 & 245,0321 \\
\hline 59,376 & 53,014 & 38,48962 & 0,328902 \\
\hline 65,737 & 43,353 & 0,024649 & 104,745 \\
\hline 69,978 & 48,773 & 19,3424 & 23,17941 \\
\hline 53,092 & 43,196 & 155,9501 & 107,9833 \\
\hline 75,476 & 60,868 & 97,93082 & 53,00568 \\
\hline 81,995 & 43,353 & 269,4522 & 104,745 \\
\hline 43,196 & 49,008 & 501,0435 & 20,97182 \\
\hline 53,014 & 52,386 & 157,9044 & 1,443602 \\
\hline 70,685 & 59,376 & 26,06103 & 33,50673 \\
\hline 63,774 & 55,134 & 3,261636 & 2,391662 \\
\hline 84,273 & 59,219 & 349,4282 & 31,71379 \\
\hline 74,769 & 54,977 & 84,43772 & 1,93071 \\
\hline 66,758 & 66,758 & 1,387684 & 173,4621 \\
\hline 44,924 & 54,192 & 426,6703 & 0,36542 \\
\hline 64,795 & 70,371 & 0,616225 & 281,6859 \\
\hline 78,461 & 57,805 & 165,9202 & 17,78731 \\
\hline
\end{tabular}




\begin{tabular}{|c|c|c|c|}
\hline$E P P\left(\square^{2}\right)$ & $C P P\left(\square^{2}\right)$ & $S Q E P P$ & $S Q C P P$ \\
\hline 74,612 & 41,469 & 81,57702 & 146,858 \\
\hline 67,387 & 45,553 & 3,265249 & 64,55319 \\
\hline 87,964 & 53,014 & 501,0435 & 0,328902 \\
\hline 69,978 & 43,196 & 19,3424 & 107,9833 \\
\hline 55,292 & 51,05 & 105,8429 & 6,438906 \\
\hline 68,329 & 53,014 & 7,557001 & 0,328902 \\
\hline 71,471 & 61,575 & 34,70388 & 63,80016 \\
\hline 96,603 & 61,496 & 962,4265 & 62,54437 \\
\hline 68,722 & 63,303 & 9,872164 & 94,39094 \\
\hline 58,904 & 63,774 & 44,56898 & 103,7648 \\
\hline 75,555 & 47,123 & 99,50063 & 41,78976 \\
\hline 61,261 & 45,16 & 18,65376 & 71,02276 \\
\hline 55,998 & 42,882 & 91,81472 & 114,6077 \\
\hline 68,329 & 45,16 & 7,557001 & 71,02276 \\
\hline 67,858 & 50,579 & 5,189284 & 9,051072 \\
\hline 51,05 & 43,196 & 211,1209 & 107,9833 \\
\hline 52,386 & 50,579 & 174,0816 & 9,051072 \\
\hline 53,014 & 47,123 & 157,9044 & 41,78976 \\
\hline 67,387 & 68,172 & 3,265249 & 212,7076 \\
\hline 64,795 & 49,48 & 0,616225 & 16,87156 \\
\hline 51,836 & 52,386 & 188,8975 & 1,443602 \\
\hline 69,429 & 42,882 & 14,8148 & 114,6077 \\
\hline 75,555 & 59,611 & 99,50063 & 36,28255 \\
\hline 65,973 & 46,181 & 0,154449 & 54,85624 \\
\hline 59,611 & 50,579 & 35,62896 & 9,051072 \\
\hline 68,722 & 55,292 & 9,872164 & 2,90532 \\
\hline 61,496 & 60,318 & 16,67906 & 45,29963 \\
\hline 59,376 & 57,019 & 38,48962 & 11,77519 \\
\hline 60,868 & 77,44 & 22,20294 & 568,9418 \\
\hline 63,303 & 59,376 & 5,184729 & 33,50673 \\
\hline 60,868 & 65,973 & 22,20294 & 153,4006 \\
\hline 45,16 & 41,547 & 416,9764 & 144,9736 \\
\hline 52,778 & 65,973 & 163,8912 & 153,4006 \\
\hline 62,831 & 70,607 & 7,557001 & 289,6634 \\
\hline
\end{tabular}




\begin{tabular}{|c|c|c|c|c|c|c|c|}
\hline Área dos túbulos ser & iníferos & dos testíc & culos de ratos & s pre-púber & es $\mathrm{e}$ & stimulad & s e con \\
\hline Grupo & $N$ & Soma & Média & Variân & cia & Desvio & padrão \\
\hline E-P-P & 58 & 3803,654 & 65,58024 & 113,80 & & $\overline{10,6}$ & 678 \\
\hline C-P-P & 58 & 3108,075 & 53,5875 & 81,279 & & & 155 \\
\hline $\begin{array}{l}\text { ANOVA }(\alpha=0,05) \text { Áre } \\
\text { estimulados e contro }\end{array}$ & dos túbu & los semin & níferos dos te & estículos de & rato & pre-pú & oeres \\
\hline Fonte da variação & $S Q$ & GI & $M Q$ & $\boldsymbol{F}$ & & alor-P & F crítico \\
\hline Entre grupos & 138,017 & 1 & 138,016667 & 16,29565 & 0,0 & 016086 & 4,0068 \\
\hline Dentro dos grupos & 491,233 & 58 & 8,46954023 & & & & \\
\hline Total & 629,25 & 59 & & & & & \\
\hline
\end{tabular}

Área dos túbulos seminíferos dos testículos de ratos adultos estimulados e controle

\begin{tabular}{|c|c|c|c|}
\hline$E A\left(\square^{2}\right)$ & $C A\left(\square^{2}\right)$ & $S Q E A$ & $S Q E A$ \\
\hline 68,329 & 65,345 & 18,215 & 77,2149 \\
\hline 75,476 & 49,008 & 130,3 & 56,9995 \\
\hline 77,754 & 52,778 & 187,496 & 14,2869 \\
\hline 69,429 & 49,48 & 28,8144 & 50,0953 \\
\hline 79,168 & 46,966 & 228,218 & 92,0026 \\
\hline 66,758 & 55,134 & 7,27327 & 2,02721 \\
\hline 64,795 & 63,774 & 0,53861 & 52,0735 \\
\hline 69,429 & 58,904 & 28,8144 & 5,50465 \\
\hline 79,717 & 47,83 & 245,107 & 76,1745 \\
\hline 76,576 & 57,805 & 156,623 & 1,55551 \\
\hline 76,34 & 65,737 & 150,771 & 84,2577 \\
\hline 67,387 & 70,685 & 11,0616 & 199,578 \\
\hline 66,837 & 68,172 & 7,70562 & 134,89 \\
\hline 70,685 & 72,57 & 43,8761 & 256,391 \\
\hline 70,371 & 78,461 & 39,8148 & 479,75 \\
\hline 68,722 & 55,134 & 21,724 & 2,02721 \\
\hline 61,261 & 58,904 & 7,84056 & 5,50465 \\
\hline 60,868 & 65,973 & 10,1959 & 88,646 \\
\hline 54,977 & 54,192 & 82,5209 & 5,59701 \\
\hline 72,57 & 60,475 & 72,4014 & 15,3445 \\
\hline
\end{tabular}




\begin{tabular}{|c|c|c|c|}
\hline$E A\left(\square^{2}\right)$ & $C A\left(\square^{2}\right)$ & SQEA & SQ EA \\
\hline 57,176 & 72,57 & 47,4046 & 256,391 \\
\hline 49,087 & 60,868 & 224,224 & 18,5778 \\
\hline 57,255 & 46,966 & 46,323 & 92,0026 \\
\hline 61,575 & 52,778 & 6,18069 & 14,2869 \\
\hline 61,261 & 50,265 & 7,84056 & 39,5993 \\
\hline 58,904 & 49,087 & 26,5957 & 55,8129 \\
\hline 53,092 & 46,181 & 120,321 & 107,678 \\
\hline 62,203 & 57,255 & 3,45254 & 0,48609 \\
\hline 59,219 & 74,22 & 23,4459 & 311,953 \\
\hline 54,663 & 58,904 & 88,3243 & 5,50465 \\
\hline 56,941 & 70,685 & 50,6958 & 199,578 \\
\hline 61,496 & 54,977 & 6,57974 & 2,49893 \\
\hline 54,977 & 62,831 & 82,5209 & 39,353 \\
\hline 54,977 & 65,659 & 82,5209 & 82,8318 \\
\hline 50,579 & 46,966 & 181,767 & 92,0026 \\
\hline 55,134 & 48,773 & 79,6931 & 60,6031 \\
\hline 80,346 & 46,966 & 265,198 & 92,0026 \\
\hline 67,387 & 57,176 & 11,0616 & 0,38217 \\
\hline 63,617 & 51,05 & 0,19722 & 30,3359 \\
\hline 47,123 & 57,176 & 286,899 & 0,38217 \\
\hline 70,607 & 57,255 & 42,8488 & 0,48609 \\
\hline 68,329 & 57,176 & 18,215 & 0,38217 \\
\hline 56,941 & 49,48 & 50,6958 & 50,0953 \\
\hline 63,774 & 63,303 & 0,08243 & 45,4977 \\
\hline 61,575 & 51,05 & 6,18069 & 30,3359 \\
\hline 63,774 & 53,014 & 0,08243 & 12,5585 \\
\hline 63,774 & 53,092 & 0,08243 & 12,0118 \\
\hline 57,176 & 53,014 & 47,4046 & 12,5585 \\
\hline 65,737 & 48,773 & 2,80864 & 60,6031 \\
\hline 55,134 & 55,134 & 79,6931 & 2,02721 \\
\hline 61,261 & 51,05 & 7,84056 & 30,3359 \\
\hline 63,774 & 47,123 & 0,08243 & 89,0155 \\
\hline 59,376 & 61,575 & 21,9502 & 25,1723 \\
\hline 70,371 & 38,013 & 39,8148 & 343,91 \\
\hline 57,255 & 68,172 & 46,323 & 134,89 \\
\hline 61,261 & 58,904 & 7,84056 & 5,50465 \\
\hline
\end{tabular}




\begin{tabular}{r|r|r|r}
\hline $\left.\boldsymbol{A} \mathbf{(}^{2}\right)$ & $\left.\boldsymbol{C A} \mathbf{(}^{2}\right)$ & ESQ EA & \multicolumn{1}{c|}{ SQ EA } \\
\hline 68,329 & 50,108 & 18,215 & 41,5999 \\
\hline 82,466 & 54,977 & 338,74 & 2,49893 \\
\hline 69,978 & 53,014 & 35,0097 & 12,5585 \\
\hline 73,042 & 46,966 & 80,6566 & 92,0026 \\
\hline 49,087 & 49,087 & 224,224 & 55,8129 \\
\hline 63,774 & 63,617 & 0,08243 & 49,8323 \\
\hline 74,22 & 57,176 & 103,203 & 0,38217 \\
\hline 65,737 & 49,087 & 2,80864 & 55,8129 \\
\hline 55,134 & 50,579 & 79,6931 & 35,746 \\
\hline 55,134 & 51,05 & 79,6931 & 30,3359 \\
\hline 57,176 & 68,172 & 47,4046 & 134,89 \\
\hline 68,722 & 63,774 & 21,724 & 52,0735 \\
\hline 63,303 & 59,376 & 0,57472 & 7,94225 \\
\hline 65,973 & 49,087 & 3,65536 & 55,8129 \\
\hline 59,219 & 55,134 & 23,4459 & 2,02721 \\
\hline 60,868 & 63,617 & 10,1959 & 49,8323 \\
\hline 79,717 & 49,087 & 245,107 & 55,8129 \\
\hline & & & \\
\hline & & & \\
\hline
\end{tabular}

Áreas dos túbulos seminíferos dos testículos de ratos adultos estimulados e controle

\begin{tabular}{c|c|c|c|c|c}
\hline Grupo & N & Soma & Média & Variância & Desvio padrão \\
\hline E A & 73 & 4676,46 & 64,0611 & 66,763 & 8,1708 \\
\hline C A & 73 & 4128,72 & 56,5578 & 66,563 & 8,1586 \\
\hline
\end{tabular}

\begin{tabular}{|c|c|c|c|c|c|c|}
\hline \multicolumn{7}{|c|}{$\begin{array}{c}\text { ANOVA }(\alpha=0,05) \text { Áreas dos túbulos seminíferos dos testículos de ratos adultos } \\
\text { estimulados e controle }\end{array}$} \\
\hline Fonte da variação & $S Q$ & $g l$ & $M Q$ & $\boldsymbol{F}$ & Valor-P & $\begin{array}{c}F \\
\text { crítico }\end{array}$ \\
\hline Entre grupos & 2054,95 & 1 & 2054,95 & 30,8259 & $\begin{array}{l}1,31945 \mathrm{E}- \\
\quad 07\end{array}$ & 3,90685 \\
\hline Dentro dos grupos & 9599,47 & 144 & 66,663 & & & \\
\hline Total & 11654,4 & 145 & & & & \\
\hline
\end{tabular}


Estadios do ciclo espermatogenético de ratos Pre-Púberes Estimulados e Controle

\begin{tabular}{c|c|c|c|c|c|c|c}
\hline Estadios & EPP & CPP & SQ EPP & \multicolumn{3}{|c}{ SQ estadios } \\
\hline VII & 6 & 25 & 592,0949 & 2,777889 & SQ VII & 90,25 & 90,25 \\
\hline VIII & 65 & 37 & 1201,801 & 106,7771 & SQ VIII & 196 & 196 \\
\hline XIV & 20 & 18 & 106,7709 & 75,11169 & SQ XIV & 1 & 1 \\
\hline
\end{tabular}

Estadios do ciclo espermatogenético de ratos Pre-Púberes Estimulados e Controle

\begin{tabular}{c|c|c|c|c|c}
\hline Resumo & N & Soma & Média & Variância & Desvio padrão \\
\hline VII & 2 & 31 & 15,5 & 180,5 & 13,4350 \\
\hline VIII & 2 & 102 & 51 & 392 & 19,7989 \\
\hline XIV & 2 & 38 & 19 & 2 & 1,4142 \\
\hline E P P & 3 & 91 & 30,33333333 & 950,3333 & 30,8274 \\
\hline C P P & 3 & 80 & 26,66666667 & 92,33333 & 9,6090 \\
\hline
\end{tabular}

\begin{tabular}{|c|c|c|c|c|c|c|}
\hline \multicolumn{7}{|c|}{ ANOVA $(\alpha=0,05)$ Estadios do ciclo espermatogenético de ratos Pre-Púberes } \\
\hline Fonte da variação & SQ & $\boldsymbol{g l}$ & MQ & $\boldsymbol{F}$ & Valor-P & F crítico \\
\hline Linhas & 1531 & 2 & 765,5 & 2,761876 & 0,265825 & 19,00003 \\
\hline Colunas & 20,16667 & 1 & 20,16666667 & 0,07276 & 0,812642 & 18,51276 \\
\hline Erro & 554,3333 & 2 & 277,1666667 & & & \\
\hline Total & 2105,5 & 5 & & & & \\
\hline \multicolumn{70}{|c|}{} & & & & \\
\hline
\end{tabular}

Estadios do ciclo espermatogenético de ratos Adultos Estimulados e Controle

\begin{tabular}{c|c|c|c|c|c|c|c|}
\hline Estadios & EA & CA & SQ & SQA & \multicolumn{3}{|c|}{ SQ estadios } \\
\hline VII & 26 & 37 & 128,4369 & 69,43889 & SQ VII & 30,25 & 30,25 \\
\hline VIII & 53 & 48 & 245,4549 & 7,112889 & SQ VIII & 6,25 & 6,25 \\
\hline XIV & 33 & 51 & 18,77489 & 32,11489 & SQ XIV & 81 & 81 \\
\hline
\end{tabular}




\begin{tabular}{|c|c|c|c|c|c|}
\hline \multicolumn{6}{|c|}{ Estadios do ciclo espermatogenético de ratos Adultos Estimulados e Controle } \\
\hline Resumo & $\mathbf{N}$ & Soma & Média & Variância & Desvio padrão \\
\hline VII & 2 & 63 & 31,5 & 60,5 & 7,7781 \\
\hline VIII & 2 & 101 & 50,5 & 12,5 & 3,5355 \\
\hline XIV & 2 & 84 & 42 & 162 & 12,7279 \\
\hline $\begin{array}{c}\text { Estimulado } \\
\text { Adulto }\end{array}$ & 3 & 112 & 37,33333333 & 196,3333 & 14,0119 \\
\hline Controle Adulto & 3 & 136 & 45,33333333 & 54,33333 & 7,3711 \\
\hline \multicolumn{7}{|l|}{} \\
\hline
\end{tabular}

\begin{tabular}{|c|c|c|c|c|c|c|}
\hline \multicolumn{8}{|c|}{ ANOVA $(\alpha=0,05)$ Estadios do ciclo espermatogenético de ratos Adultos Estimulados } \\
e Controle \\
\hline Fonte da variação & SQ & gl & MQ & F & Valor-P & F crítico \\
\hline Linhas & 362,3333 & 2 & 181,1666667 & 2,606715 & 0,277261 & 19,00003 \\
\hline Colunas & 96 & 1 & 96 & 1,381295 & 0,360852 & 18,51276 \\
\hline Erro & 139 & 2 & 69,5 & & & \\
\hline Total & 597,3333 & 5 & & & & \\
\hline
\end{tabular}

Peso dos testículos de ratos adultos estimulados direito (TED) esquerdo (TE
\begin{tabular}{c|c|c|c}
\hline TED & TEE & SQ TED & SQ TEE \\
\hline 1,69 & 1,66 & 0,016129 & 0,028561 \\
\hline 1,83 & 1,9 & 0,000169 & 0,005041 \\
\hline 1,82 & 1,79 & $9 \mathrm{E}-06$ & 0,001521 \\
\hline 1,82 & 1,86 & $9 \mathrm{E}-06$ & 0,000961 \\
\hline 1,85 & 1,89 & 0,001089 & 0,003721 \\
\hline 1,87 & 1,89 & 0,002809 & 0,003721 \\
\hline 1,73 & 1,8 & 0,007569 & 0,000841 \\
\hline 1,91 & 1,87 & 0,008649 & 0,001681 \\
\hline 1,86 & 1,88 & 0,001849 & 0,002601 \\
\hline 1,79 & 1,75 & 0,000729 & 0,006241 \\
\hline
\end{tabular}




\begin{tabular}{|c|c|c|c|c|c|}
\hline \multicolumn{6}{|c|}{ Peso dos testículos de ratos adultos estimulados direito (TED) esquerdo (TEE) } \\
\hline Grupo & $\mathbf{N}$ & Soma & Média & Variância & Desvio padrão \\
\hline Estimulado (ETD) & 10 & 18,17 & 1,817 & 0,00433 & 0,0658 \\
\hline Estimulado (ETE) & 10 & 18,29 & 1,829 & 0,0060 & 0,0780 \\
\hline
\end{tabular}

ANOVA $(\alpha=0,05)$ Peso dos testículos de ratos adultos estimulados direito (TED) esquerdo (TEE)

\begin{tabular}{c|c|c|c|c|c|c}
\hline Fonte da variação & $\mathbf{S Q}$ & $\boldsymbol{g l}$ & $\mathbf{M Q}$ & $\boldsymbol{F}$ & Valor-P & $\boldsymbol{F}$ crítico \\
\hline Entre grupos & 0,00072 & 1 & 0,00072 & 0,1380 & 0,7145 & 4,4138 \\
\hline Dentro dos grupos & 0,0939 & 18 & 0,005217 & & & \\
\hline Total & 0,09462 & 19 & & & & \\
\hline
\end{tabular}

\begin{tabular}{|c|c|c|c|c|c|}
\hline \multicolumn{6}{|c|}{ Peso dos testículos de ratos adultos controle direito (TCD) esquerdo (TCE) } \\
\hline$T C D$ & $T C$ & & SQ TCD & SQ TCE & \\
\hline 1,96 & \multicolumn{2}{|c|}{1,96} & 0,0625 & \multicolumn{2}{|c|}{0,050176} \\
\hline 1,62 & \multicolumn{2}{|c|}{1,72} & 0,0081 & \multicolumn{2}{|c|}{0,000256} \\
\hline 1,67 & \multicolumn{2}{|c|}{1,74} & 0,0016 & \multicolumn{2}{|c|}{0,000016} \\
\hline 1,65 & \multicolumn{2}{|c|}{1,69} & 0,0036 & \multicolumn{2}{|c|}{0,002116} \\
\hline 1,81 & \multicolumn{2}{|c|}{1,82} & 0,01 & \multicolumn{2}{|c|}{0,007056} \\
\hline 1,63 & \multicolumn{2}{|c|}{1,61} & 0,0064 & \multicolumn{2}{|c|}{0,015876} \\
\hline 1,62 & \multicolumn{2}{|c|}{1,64} & 0,0081 & \multicolumn{2}{|c|}{0,009216} \\
\hline 1,69 & \multicolumn{2}{|c|}{1,71} & 0,0004 & \multicolumn{2}{|c|}{0,000676} \\
\hline 1,76 & \multicolumn{2}{|c|}{1,78} & 0,0025 & \multicolumn{2}{|c|}{0,001936} \\
\hline 1,69 & \multicolumn{2}{|c|}{1,69} & 0,0004 & \multicolumn{2}{|c|}{0,002116} \\
\hline \multicolumn{6}{|c|}{ Peso dos testículos de ratos adultos controle direito (TCD) esquerdo (TCE) } \\
\hline Grupo & $N$ & Soma & Média & Variância & Desvio padrão \\
\hline TCD & 10 & 17,1 & 1,71 & 0,011511 & 0,10728 \\
\hline TCE & 10 & 17,36 & 1,736 & 0,009938 & 0,09968 \\
\hline
\end{tabular}




\begin{tabular}{|l|c|c|c|c|c|c|}
\hline \multicolumn{7}{|c|}{ ANOVA $(\alpha=0,05)$ Peso dos testículos de ratos adultos controle direito (TCD) } \\
esquerdo (TCE) \\
\hline Fonte da variação & SQ & gl & MQ & F & Valor-P & F crítico \\
\hline Entre grupos & 0,00338 & 1 & 0,00338 & 0,315168 & 0,581449084 & 4,413863 \\
\hline Dentro dos grupos & 0,19304 & 18 & 0,010724444 & & & \\
\hline Total & 0,19642 & 19 & & & & \\
\hline
\end{tabular}

